\title{
Spatial and Temporal Distribution of the Brown Marmorated Stink Bug (Hemiptera: Pentatomidae)
}

Jakob Goldner

Follow this and additional works at: https://researchrepository.wvu.edu/etd

\section{Recommended Citation}

Goldner, Jakob, "Spatial and Temporal Distribution of the Brown Marmorated Stink Bug (Hemiptera: Pentatomidae)" (2016). Graduate Theses, Dissertations, and Problem Reports. 5690.

https://researchrepository.wvu.edu/etd/5690

This Thesis is protected by copyright and/or related rights. It has been brought to you by the The Research Repository @ WVU with permission from the rights-holder(s). You are free to use this Thesis in any way that is permitted by the copyright and related rights legislation that applies to your use. For other uses you must obtain permission from the rights-holder(s) directly, unless additional rights are indicated by a Creative Commons license in the record and/ or on the work itself. This Thesis has been accepted for inclusion in WVU Graduate Theses, Dissertations, and Problem Reports collection by an authorized administrator of The Research Repository @ WVU. For more information, please contact researchrepository@mail.wvu.edu. 


\title{
Spatial and Temporal Distribution of the Brown Marmorated Stink Bug (Hemiptera: Pentatomidae)
}

\author{
Jakob Goldner \\ Thesis submitted \\ to the Davis College of Agriculture, Natural Resources and Design \\ at West Virginia University \\ in partial fulfillment of the requirements \\ for the degree of \\ Master of Science in \\ Plant and Soil Science - Entomology
}

Yong-Lak Park, Ph.D., Chair

Daniel Frank, Ph.D.

James Kotcon, Ph.D.

Division of Plant and Soil Sciences

Morgantown, West Virginia 26506

2016

Keywords: Halyomorpha halys, spatial distribution, SADIE, population dynamics Copyright 2016 Jakob Goldner 


\title{
ABSTRACT \\ Spatial and Temporal Distribution of the Brown Marmorated Stink Bug (Hemiptera: Pentatomidae)
}

\begin{abstract}
Jakob Goldner
An obstacle to efficient management of the brown marmorated stink bug, Halyomorpha halys (Hemiptera: Pentatomidae), is the lack of knowledge of its seasonal movements at the landscape level. H. halys is highly mobile and utilizes various commodities throughout the growing season and winter, making it difficult to manage. We hypothesized that $H$. halys displayed an annual spatial pattern at the farm scale and as they moved into overwintering habitats. To test for a spatial pattern at the farm scale, we conducted a two-year spatial study on three organic farms in West Virginia and New Jersey. A total of 92-127 sample locations throughout each farm were plotted using a global positioning system and were visually surveyed for $H$. halys nymphs and adults from May through November in 2012-2014. Count data were paired with geocoordinates to perform spatial analysis by distance indices (SADIE) to characterize spatial distribution patterns and spatial associations of $H$. halys with commodities. West Virginia populations displayed two peaks (late May - early June and mid-September), while the New Jersey population displayed only one (July). Crops bearing the largest numbers of $H$. halys included pears, apples, cherries, peaches, and berries. Results indicate $H$. halys was randomly distributed over the commodity types throughout the growing season. Significant spatial patterns consisted of gaps with relatively low populations covering much of the cropping areas, and patches with relatively high populations observed on trees, wild blackberry, corn, and peppers. Gaps often coincided with apparently suitable host-plants, such as tomatoes or peppers. Positive spatial associations between years suggests that areawide pest management could be used to control populations if patches are identified.
\end{abstract}

To test for a spatial pattern at overwintering sites, we surveyed a shopping center in Morgantown, West Virginia for two years to determine when and where H. halys was present in greatest numbers, as well as whether or not it is associated with a preferred surface aspect (northwest, northeast, southeast, or southwest), or surface type (wall or entryway). There was a relationship between numbers of $H$. halys and surface aspect $(P<0.05)$, and significantly $(P<$ $0.05)$ more insects were found on entryways. Count data were paired with geo-coordinates to perform spatial analysis by distance indices (SADIE) to characterize spatial distribution patterns and spatial associations of $H$. halys. Results indicate $H$. halys was randomly distributed over the site. No significant spatial patterns consisting of gaps with relatively low populations, or patches with relatively high populations were observed. Positive spatial associations between sample weeks across years suggests that these findings could be used to help create a pest management plan to control populations if patches are identified. 


\section{TABLE OF CONTENTS}

Chapter 1 Introduction

Thesis Organization 1

General Introduction 1

Objectives of Study 2

Literature Review 4

$\begin{array}{ll}\text { Literature Cited } & 9\end{array}$

Chapter 2 Spatial and temporal distribution of Halyomorpha halys (Hemiptera:

Pentatomidae) in organic farming systems

$\begin{array}{ll}\text { Abstract } & 16 \\ \text { Materials and Methods } & 19 \\ \text { Results } & 21 \\ \text { Discussion } & 23 \\ \text { Literature Cited } & 24\end{array}$

Chapter 3 Movement of Halyomorpha halys (Hemiptera: Pentatomidae) to overwintering sites in urban habitat

Abstract 43

Materials and Methods $\quad 46$

Results 48

$\begin{array}{ll}\text { Discussion } & 50\end{array}$

Literature Cited $\quad 52$

Chapter 4 General Conclusion

$\begin{array}{ll}\text { Conclusion } & 69\end{array}$

$\begin{array}{ll}\text { Literature Cited } & 70\end{array}$

$\begin{array}{lll}\text { Appendices } & \text { Appendix } 1 & \text { i }\end{array}$ 


\section{LIST OF TABLES}

Chapter 2 Spatial and temporal distribution of Halyomorpha halys (Hemiptera: Pentatomidae) in organic farming systems

Table 1. List of types of landscape elements and corresponding land use and commodities

Table 2. SADIE statistics for the spatial distribution of $H$. halys nymphs. ${ }^{a}$ Overall degree of clustering $\left(I_{\mathrm{a}}\right)$ with its associated $P$ value $\left(P_{\mathrm{a}}\right)$ in parenthesis. $I_{\mathrm{a}}=1$ suggests a random, $I_{\mathrm{a}}>1$ suggests an aggregated, and $I_{\mathrm{a}}<1$ suggests a regular spatial pattern. Significant $(P<0.05)$ associations are in bold. $\mathrm{n} / \mathrm{a}$ listed when SADIE could not be conducted (0 individuals found).

spatial pattern. Significant $(P<0.05)$ associations are in bold

Table 3. SADIE statistics for the spatial distribution of $H$. halys adults. ${ }^{a}$ Overall degree of clustering $\left(I_{\mathrm{a}}\right)$ with its associated $P$ value $\left(P_{\mathrm{a}}\right)$ in parenthesis. $I_{\mathrm{a}}=1$ suggests a random, $I_{\mathrm{a}}>1$ suggests an aggregated, and $I_{\mathrm{a}}<1$ suggests a regular spatial pattern. Significant $(P<0.05)$ associations are in bold. $\mathrm{n} / \mathrm{a}$ listed when SADIE could not be conducted (0 individuals found).

Table 4. SADIE statistics for the spatial distribution of total $H$. halys. ${ }^{a}$ Overall degree of clustering $\left(I_{\mathrm{a}}\right)$ with its associated $P$ value $\left(P_{\mathrm{a}}\right)$ in parenthesis. $I_{\mathrm{a}}=1$ suggests a random, $I_{\mathrm{a}}>1$ suggests an aggregated, and $I_{\mathrm{a}}<1$ suggests a regular spatial pattern. Significant $(P<0.05)$ associations are in bold. $\mathrm{n} / \mathrm{a}$ listed when SADIE could not be conducted (0 individuals found).

Table 5. SADIE statistics for the spatial distribution of total $H$. halys in early, mid, and late seasons. Index of association $(X)$ with its associated $P$ value $\left(P_{\mathrm{t}}\right)$ in parenthesis. For a two-tail test at $95 \%$ confidence level, $P_{\mathrm{t}}<0.025$ indicates significant positive association and $P_{\mathrm{t}}>0.975$ indicates significant negative association. Significant associations are in bold

Table 6. Spatial association of $H$. halys nymphs, adults, and totals within years. Index of association $(X)$ with its associated $P$ value $\left(P_{\mathrm{t}}\right)$ in parenthesis. For a twotail test at $95 \%$ confidence level, $P_{\mathrm{t}}<0.025$ indicates significant positive association and $P_{\mathrm{t}}>0.975$ indicates significant negative association. Significant associations are in bold. $\mathrm{n} / \mathrm{a}$ listed when SADIE could not be conducted ( 0 individuals found).

Table 7. Spatial association of total $H$. halys in early, mid, and late season.

${ }^{\text {a }}$ Index of association $(X)$ with its associated $P$ value $\left(P_{\mathrm{t}}\right)$ in parenthesis. For a twotail test at $95 \%$ confidence level, $P_{\mathrm{t}}<0.025$ indicates significant positive association and $P_{\mathrm{t}}>0.975$ indicates significant negative association. Significant associations are in bold. $\mathrm{n} / \mathrm{a}$ listed when SADIE could not be conducted ( 0 individuals found).

Chapter 3 Movement of Halyomorpha halys (Hemiptera: Pentatomidae) to overwintering sites in an urban habitat

Table 1. Results of one-way ANOVA for the number $H$. halys per surface aspect (northwest, northeast, southeast, and southwest)

Table 2. Results of ANOVA for the number H. halys per year with four different surface aspects (northwest, northeast, southeast, and southwest) 
Table 3. Table 3. Results of ANOVA for the number $H$. halys per year with two different surface types (walls, and entryways)

Table 4. SADIE statistics for the spatial distribution of $H$. halys found in the morning. Overall degree of clustering $\left(I_{\mathrm{a}}\right)$ with its associated $P$ value $\left(P_{\mathrm{a}}\right)$ in parenthesis. $I_{\mathrm{a}}=1$ suggests a random, $I_{\mathrm{a}}>1$ suggests an aggregated, and $I_{\mathrm{a}}<1$ suggests a regular spatial pattern. Significant $(P<0.05)$ associations are in bold. $\mathrm{n} / \mathrm{a}$ listed when SADIE could not be conducted (0 individuals found).

Table 5. Spatial association of $H$. halys found at in the morning, noon, and evening within years. Index of association $(X)$ with its associated $P$ value $\left(P_{\mathrm{t}}\right)$ in parenthesis. For a two-tail test at $95 \%$ confidence level, $P_{\mathrm{t}}<0.025$ indicates significant positive association and $P_{\mathrm{t}}>0.975$ indicates significant negative association. Significant associations are in bold. $\mathrm{n} / \mathrm{a}$ listed when SADIE could not be conducted ( 0 individuals found).

Table 6. Spatial association of $H$. halys found in the morning, noon, and evening between years. Index of association $(X)$ with its associated $P$ value $\left(P_{\mathrm{t}}\right)$ in parenthesis. For a two-tail test at $95 \%$ confidence level, $P_{\mathrm{t}}<0.025$ indicates significant positive association and $P_{\mathrm{t}}>0.975$ indicates significant negative association. Significant associations are in bold. $\mathrm{n} / \mathrm{a}$ listed when SADIE could not be conducted ( 0 individuals found).

Table 7. SADIE statistics for the spatial distribution of $H$. halys found at noon. Overall degree of clustering $\left(I_{\mathrm{a}}\right)$ with its associated $P$ value $\left(P_{\mathrm{a}}\right)$ in parenthesis. $I_{\mathrm{a}}$ $=1$ suggests a random, $I_{\mathrm{a}}>1$ suggests an aggregated, and $I_{\mathrm{a}}<1$ suggests a regular spatial pattern. Significant $(P<0.05)$ associations are in bold. $\mathrm{n} / \mathrm{a}$ listed when SADIE could not be conducted ( 0 individuals found).

Table 8. SADIE statistics for the spatial distribution of $H$. halys found in the evening. Overall degree of clustering $\left(I_{\mathrm{a}}\right)$ with its associated $P$ value $\left(P_{\mathrm{a}}\right)$ in parenthesis. $I_{\mathrm{a}}=1$ suggests a random, $I_{\mathrm{a}}>1$ suggests an aggregated, and $I_{\mathrm{a}}<1$ suggests a regular spatial pattern. Significant $(P<0.05)$ associations are in bold. $\mathrm{n} / \mathrm{a}$ listed when SADIE could not be conducted (0 individuals found).

Table 9. SADIE statistics for the spatial distribution of total $H$. halys found. Overall degree of clustering $\left(I_{\mathrm{a}}\right)$ with its associated $P$ value $\left(P_{\mathrm{a}}\right)$ in parenthesis. $I_{\mathrm{a}}=1$ suggests a random, $I_{\mathrm{a}}>1$ suggests an aggregated, and $I_{\mathrm{a}}<1$ suggests a regular spatial pattern. Significant $(P<0.05)$ associations are in bold. $\mathrm{n} / \mathrm{a}$ listed when SADIE could not be conducted (0 individuals found). 


\section{LIST OF FIGURES}

Chapter 1 Introduction

Figure 1. Halyomorpha halys adult feeding on peach.

Chapter 2 Spatial and temporal distribution of Halyomorpha halys (Hemiptera:

Pentatomidae) in organic farming systems.

Figure 1. Arrangement of sample locations throughout the West Virginia 35 University organic farm (Morgantown, West Virginia)

Figure 2. Arrangement of sample locations throughout Redbud organic farm 36 (Inwood, West Virginia)

Figure 3. Arrangement of sample locations throughout the Muth family

organic farm (Williamstown, New Jersey)

Figure 4. Total number of $H$. halys observed per year at each site 38

Figure 5. Total number of $H$. halys on plants and structures per sample week 39 in 2013-2014 in a) Morgantown, b) Inwood, and c) Williamstown

Figure 6. Map of patches and gaps in observations of $H$. halys in 2013 in

Morgantown, West Virginia. Red areas indicate patches with clusters of relatively large counts (i.e., $v_{i}>1.5$ ) and blue areas indicate gaps with clusters of relatively small counts (i.e., $v_{i}<-1.5$ )

Figure 7. Large numbers of $H$. halys adults overwintering in a shed

Chapter 3 Movement of Halyomorpha halys (Hemiptera: Pentatomidae) to overwintering sites in an urban habitat.

Figure 1. Average number of $H$. halys observed per year at three different times of day (morning, evening, and noon) in a) 2013, and b)

Figure 2. Average number of $H$. halys observed per surface aspect per year at four different directions: northeast, northwest, southeast, and southwest

Figure 3. Average number of $H$. halys observed per year on two surface types: wall and entryway

Figure 4. Maps of patches and gaps in observations of $H$. halys in 2013: a) morning, b) noon, c) evening, and d) total. Red circles indicate patches with clusters of relatively large counts (i.e., $v_{i}>1.5$ ) and blue circles indicate gaps with clusters of relatively small counts (i.e., $v_{i}<-1.5$ ).

Figure 5. Maps of patches and gaps in observations of $H$. halys in 2014: a)

morning, b) noon, c) evening, and d) total. Red circles indicate patches with clusters of relatively large counts (i.e., $v_{i}>1.5$ ) and blue circles indicate gaps with clusters of relatively small counts (i.e., $v_{i}<-1.5$ ). 


\section{CHAPTER 1: INTRODUCTION}

\section{Thesis organization}

This thesis is organized into four chapters. Chapter 1 is a general introduction to the study and a literature review. Chapter 2 describes spatial and temporal distribution of Halyomorpha halys Stål (Hemiptera: Pentatomidae), the brown marmorated stink bug in organic farming systems. Chapter 3 analyzes spatial patterns of $H$. halys movement in an urban environment. Chapter 4 provides a general conclusion for this study. This thesis was prepared according to the publication guidelines established by the Entomological Society of America.

\section{General Introduction}

During the last decade, growers and home owners in the United States witnessed the invasion of their farms, forests, and homes by H. halys. H. halys is ubiquitous throughout eastern Asia, where it is regarded as only an occasional pest of various crops including soybean, persimmon, and pear (Xu et al. 2014). Upon H. halys' introduction and subsequent population increase, fruit growers in the Mid-Atlantic region (New York, Pennsylvania, New Jersey, Maryland, West Virginia, Delaware, Virginia, and North Carolina) have noticed an increase in damage to their orchards (Leskey et al. 2012a). While H. halys damage does not always render the crops unusable, it greatly reduces their market value (Leskey et al. 2012b).

Most growers combat the threat by $H$. halys with insecticide applications throughout the season. These applications are neither economically nor environmentally sound because growers tend to overuse or use broad-spectrum insecticides that could harm beneficial species (Leskey et al. 2012b). Moreover, organic growers face unique challenges with additional restrictions on which chemicals they may use for treatments (USDA AMS 7 CFR § 205). To maintain organic 
certification, growers cannot use many conventional insecticides. Instead, many attempt to manage pests, including $H$. halys, through biological control and crop management (Matthews 2014, personal communication). While row covers are also recommended to control $H$. halys damage, none of our research sites utilized them.

Although it is commonly reported as a nuisance pest in homes, little is known about how $H$. halys moves from the field to overwintering sites including garages, sheds, and attics. In 2013 and 2014, the USDA led a citizen science project in which volunteers provided details on the structure of their homes and daily counts of $H$. halys. However, these findings have not been published.

This research is intended to increase understanding of $H$. halys' seasonal distribution patterns throughout several different habitats and provide growers with a guideline to assess the risk of farm invasion by $H$. halys. Spatial and temporal distributions must be combined to accurately depict the movement of $H$. halys at the farm scale. Growers need access to this information to plan management practices to control H. halys damage on their farms. Specifically, this research is intended to provide growers with information on which crops bear the highest concentrations of $H$. halys, so that they know where to treat for maximum efficacy.

\section{Objectives of Study}

The goal of this research is to increase understanding of the seasonal movements of $H$. halys, providing growers and managers with information on which plants or cover types they utilize and when they may be present at these commodities.

1. Characterizing spatial and temporal distribution of $H$. halys in organic farming systems (Chapter 2). 
2. Determining spatial patterns of $H$. halys movement in an urban environment (Chapter 3).

\section{Literature Review}

\section{History of H. halys in North America}

H. halys was first reported in the United States near Allentown, PA in the 1996 (Hoebeke and Carter 2003). By sequencing mitochondrial DNA and RNA, Xu et al. (2014) determined that the Mid-Atlantic's H. halys population originated near Beijing, China. Since that time, it has steadily spread across at least 41 states in the Mid-Atlantic, the South, and the West Coast (Jones and Lambdin 2009). H. halys has been reported as a pest of tree fruits, vegetables, small fruits, and row crops (Leskey et al. 2012a). In 2010 alone, Mid-Atlantic apple growers reported economic losses of over $\$ 37$ million (Krawczyk and Hull 2011). In addition to apples, peaches, soybeans, sweet corn, peppers, and tomatoes can be damaged by the feeding activity of $H$. halys (Leskey et al. 2012a, Nielsen et al. 2011 Kuhar et al. 2012). Initial management protocols followed recommendations for native pentatomid infestation, with limited effectiveness (Leskey et al 2012a).

\section{Life History}

H. halys are hemimetabolic, completing five stadia before reaching adulthood. Egg development occurs from 15 to $33^{\circ} \mathrm{C}$ (Nielsen et al. 2008). In the Mid-Atlantic region, oviposition begins as early as May (Bakken et al. 2015, Basnet et al. 2015) or June (Bergh and Leskey 2015). First instar nymphs emerge about a week after eggs are laid, but remain aggregated on the egg mass until they reach the second instar (Leskey et al. 2012b). It has been suggested that during this time they acquire a gut symbiont from their mother (Taylor et al. 
2014). Nymphs reach adulthood after approximately five weeks (Medal et al. 2013) or 538 degree days, with females requiring another 148 degree days to oviposit (Nielsen et al. 2009a).

H. halys has a piercing-sucking mouthpart. It feeds by inserting its stylet into a fruit, stem, or other vegetative part of a plant and sucking out nutrients. This feeding causes damage to many plants, including fruits such as apple, cherry, and pears (Fig. 1) (Nielsen and Hamilton 2009b). H. halys feeding leaves characteristic corky areas in the fruits' flesh, leading to depressions in the skin. Additionally, $H$. halys feeding can induce aborted fruit, and yellowed scars on the skin (Nielsen and Hamilton 2009b). Feeding damage from H. halys does not always render the fruit useless. However, it does significantly lower its value as it may only be sold for processing (Nielsen and Hamilton 2009b). Overwintering adults mate in the spring, after emerging from their overwintering habitats (Leskey et al. 2012b). It is thought that females are not reproductively mature when they emerge from diapause, and must feed on a host plant to complete ovarian development (Nielsen and Hamilton 2009a). Females deposit 20 to 30 eggs on the undersides of leaves 14 to 25 days after mating (Hoebeke and Carter 2003, Medal et al. 2013). In the Mid-Atlantic States, only one generation of $H$. halys per year has been confirmed (Nielsen and Hamilton 2009b). However, as many as six generations per year have been recorded in warmer climates (Hoebeke and Carter 2003). Nielsen and Hamilton (2009a) indicated that there would be potential for two generations per year in West Virginia, supported by a partial second generation observed in the Appalachian Mountains region (Bakken et al. 2015).

\section{H. halys Distribution in Agricultural Environment}

Currently growers rely on scheduled insecticide sprays to combat $H$. halys because they cannot predict when or where $H$. halys will invade their orchards and fields. Several studies 
have examined temporal distribution within orchards (Leskey et al. 2012b, Nielsen and Hamilton 2009b). Nielsen and Hamilton (2009b) demonstrated that $H$. halys was capable of causing damage to apple, pear, and peaches, noting that the greatest number of adults occurred from July to August. Leskey et al. (2012b) monitored stinkbug presence and damage in orchards in 2011 and 2012, finding that $H$. halys begins feeding after fruit set and continues through the growing season, resulting in economic injury to the fruit. Additionally, previous studies did not consider various types of agricultural systems and crops coexisting on a farm. Research in vegetable fields has been focused on recording damage and risk potentials, and temporal distribution in specific crops (Leskey et al. 2012a, Nielsen et al. 2011, Owens et al. 2013).

H. halys is known to utilize at least 169 host plants (Bergmann et al. 2014). These include crop plants, ornamental plants, and wild plants. H. halys' versatility makes it difficult to anticipate which crops will experience the highest concentrations. Preliminary data suggests that H. halys aggregate at various times throughout the growing season (Organic Research and Education Initiative 2012). It may be possible to discover a predictable arrangement, or pattern, within these aggregation cycles, allowing more effective management of $H$. halys.

Previously, no research had been conducted on the spatial and temporal distributions of H. halys. However, several similar studies were done on other stink bug species. Tillman et al. (2009) used inverse distance weighting to interpolate densities and create population maps of Nezara viridula L. (Hemiptera: Pentatomidae) and Euschistus servus (Say) (Hemiptera: Pentatomidae) in peanut-cotton systems. Additionally, they used spatial analysis by distance indices (SADIE) to determine the level of aggregation and the spatial association of stink bugs in different crops. They found that both species matured in peanut fields and shifted to cotton fields as bolls developed. $N$. viridula and E. servus were aggregated where the two crops met, 
creating an edge effect. Reay-Jones (2010) completed a similar project in wheat systems. Four native species of stink bug comprised most of the population. Inverse distance weighting was used to produce maps of stink bug distribution, while indices of dispersion and $\chi^{2}$ goodness-of-fit tests were used to determine the level of randomness in distribution. Indices of dispersion, and $\chi^{2}$ suggested that stink bug spatial distribution was not random. Since these studies found nonrandom distributions of similar species, it is reasonable to hypothesize that $H$. halys will also have a non-random distribution.

Recently, several studies have focused on the temporal and spatial distributions of $H$. halys within orchards (Leskey et al. 2012a and b, Krawczyk and Hul 2011, Nielsen and Hamilton 2009), vineyards (Basnet et al. 2015), woody plant nurseries (Venugopal et al. 2015), and nonmanaged woodlands (Bakken et al. 2015). Additionally, large-scale spatial studies on $H$. halys have been conducted. Zhu et al. (2012) predicted the potential worldwide distribution of $H$. halys using climatic niche factors, and Wallner et al. (2014) used light traps to determine which landscape factors are associated with the statewide invasion of New Jersey by H. halys.

However, neither of these studies analyzed spatial data at the farm level. Venugopal et al. (2015) and Basnet et al. (2015) found that $H$. halys displays an edge effect, with higher densities found nearer the edges of cultivated areas. However, none of these studies have sought a spatial distribution pattern in $H$. halys occurrence. Understanding of such a pattern could be used to direct management efforts, focusing on areas that experience large populations annually and avoiding areas with low populations.

\section{H. halys Distribution in Urban Environment}

Human-made structures serve as a key overwintering habitat for H. halys (Hoebeke and Carter 2003). Adults congregate on outer surfaces of buildings in late September through 
November, before moving inside (Hoebeke and Carter 2003). Once indoors, the adults aggregate in cool, dark spaces, such as attics, garages, and closets (personal observation). On warmer days they become active, creating nuisance problems. There is potential for physical control of $H$. halys in overwintering habitat; overwintering box traps are already commonly used (Lee et al. 2013). Diapause makes $H$. halys easy to capture and dispose of, if a proper management schedule can be constructed. However, since $H$. halys is highly mobile, homes and gardens are likely to be recolonized after treatment. Therefore, landscape-level management, management of insects at large spatial scales, could provide greater opportunity for effective control. By understanding which types of land use harbor large concentrations of $H$. halys, it is possible to perform effective landscape-level control. Thus far, there have been no publications concerning spatial and temporal distribution of $H$. halys in urban environments, so it is not yet known which landscape features, if any, influence their distribution.

\section{Spatial Analysis of Insect Distribution}

Geographical information systems (GIS) are valuable tools for understanding an organism's distribution across a landscape. While multiple studies have applied GIS to vertebrate animals, it is also useful for displaying invertebrate distribution information (Mawdsley 2001). A GIS is a set of computer programs designed to store, manipulate, analyze, and display spatial data (Strickland et al. 1998). It can illustrate where organisms occur in the greatest abundance and what biotic and abiotic features accompany them. GIS works by georeferencing two kinds of data, raster and vector. Raster data are grid-based, with each cell categorized. This is used to assign specific attributes to each cell in the grid-covered landscape. Examples of raster data include aerial images, land cover, and land use data. Vector data are specific shapes including points, lines, or polygons. Vector data are typically used to identify features such as streams, 
structures, or sample points. Frequently, raster data in the form of an aerial image are combined with vector data, such as points, to produce a map illustrating where sample locations are located on the landscape (Strickland et al. 1998). In agriculture, GIS are frequently used to create prescription maps in precision agriculture or site-specific pest management (Park and Krell 2005, Strickland et al. 1998). Prescription maps combine several datasets, or layers, to show exactly where management should be focused. Using these maps, GPS systems, and variable rate technology, growers can practice precision farming (Park et al. 2007).

By combining GIS maps with spatial analysis such as SADIE and geostatisics, it is possible to develop models of known and potential distributions of the organism in question. Geostatisics is a statistical method used to calculate spatial correlation (Schotzko and O'Keeffe 1990). This correlation can be used in kriging, a process of interpolating counts between sample points (Liebhold et al. 1993). SADIE is a method of describing georeferenced count data as aggregated, randomly, or uniformly dispersed. It calculates the minimum effort required for individuals in a population to become randomly distributed (Perry et al. 1999). These techniques may then be combined to produce prescription maps. Prescription maps depict the location and densities of a species on a landscape. Managers can use prescription maps to manage the species more effectively.

\section{Literature Cited}

Bakken A. J., S. C. Schoof, M. Bickerton, K. L. Kamminga, J. C. Jenrette, S. Malone, M. A. Abney, D. A. Herbert, D. Reisig, T. P. Kuhar, and J. F. Walgenbach. 2015. Occurrence of brown marmorated stink bug (Hemiptera: Pentatomidae) on wild hosts in nonmanaged 
woodands and soybean fields in North Carolina and Virginia. Environ. Entomol. 44: 10111021.

Basnet S., T. P. Kuhar, C. A. Laub, and D. G. Pfeiffer. 2015. Seasonality and distribution of brown marmorated stink bug (Hemiptera: Pentatomidae) in Virginia vineyards. J. Econ. Entomol. 108: 1902-1909.

Bergh J. C., and T. C. Leskey. 2015. Spring emergence patterns of overwintering brown marmorated stink bugs Halyomorpha halys (Hemiptera: Pentatomidae), from manufactured shelters. In Proceedings of the IOBC-WPRS Working Group "Integrated plant protection in fruit crops; subgroups pome fruit arthropods and stone fruits”, 6-9 October 2014, Vienna Austria.

Bergmann, E.J., K.M. Bernhard, G. Bernon, M. Bickerton, S. Gill, C. Gonzales, G. C. Hamilton, C. Hedstrom, K. Kamminga, C. Koplinka-Loehr, et al. 2014. Host plants of the brown marmorated stink bug in the U.S. StopBMSB.org. http://www.stopbmsb.org/where-isbmsb/hostplants/

Hoebeke E., and E. C. Carter. 2003. Halyomorpha halys (Stål) (Heteroptera: Pentatomidae): A polyphagous plant pest from Asia newly detected in North America. Proc. Entomol. Soc. Wash. 105: 225-237.

Jones, J. R., and P. L. Lambdin. 2009. New county and state records for Tennessee of an exotic pest, Halyomorpha halys (Hemiptera: Pentatomidae), with potential economic and ecological implications. Fla. Entomol. 92: 177-178. 
Krawczyk, G., and L. Hull. 2011. Management options for the control of brown marmorated stink bug, a Pennsylvania perspective, pp. 1-5. In Penn State University Extension (eds.), Fruit times, College Park, PA.

Kuhar, T. P., K. L. Kamminga, J. Whalen, G. Dively, G. Brust, C. Hooks, G. Hamilton, and D. Herbert. 2012. The pest potential of brown marmorated stink bug in vegetable crops. Plant Health Prog. 0523-01

Lee, D.-H., B. D. Short, S. V. Joseph, J. C. Bergh, and T. C. Leskey. 2013. Review of the biology, ecology, and management of Halyomorpha halys (Hemiptera: Pentatomidae) in China, Japan, and the Republic of Korea. Environ. Entomol. 42: 627-641.

Leskey, T. C., C. G. Hamilton, A. L. Nielsen, D. F. Polk, C. Rodriguez-Saona., J. C. Bergh, and S. E. Wright. 2012a. Pest status of the brown marmorated stink bug, Halyomorpha halys in the USA. Outl. Pest Manag. 23: 218-226.

Leskey, T. C., B. D. Short, B. R. Butler, and S. E. Wright. 2012b. Impact of the invasive brown barmorated stink bug, Halyomorpha halys (Stål), in Mid-Atlantic Tree Fruit Orchards in the United States: Case studies of commercial management. Psyche 2012: 1-14.

Liebhold, A. M., R. E. Rossi, and W. P. Kemp. 1993. Geostatistics and geographic information systems in applied insect ecology. Annu. Rev. Entomol. 38: 303-327.

Mawdsley, J. R. 2001. Ecology, biogeography, and conservation of checkered beetles (Insecta: Coleoptera: Cleridae) in southeastern Arizona: a geographic information system (GIS) study. Trans. Am. Entomol. Soc. 127: 431-449. 
Medal, J., T. Smith, A. Fox, A. Santa Cruz, A. Poplin, and A. Hodges. 2012. Rearing the brown marmorated stink bug Halyomorpha halys (Hemiptera: Pentatomidae). Fla. Entomol. 95: 800-802.

Nielsen, A. L., and G. C. Hamilton. 2009a. Life history of the invasive species Halyomorpha halys (Hemiptera: Pentatomidae) in Northeastern United States. Ann. Entomol. Soc. Am. 102: 608-616.

Nielsen A. L., and G. C. Hamilton. 2009b. Seasonal occurrence and impact of Halyomorpha halys (Hemiptera: Pentatomidae) in tree fruit. J. Econ. Entomol. 102: 1133-1140.

Nielsen A. L., Hamilton G. C., and D. Matadha. 2008. Developmental rate estimatin and life table analysis for Halyomorpha halys (Stål) (Hemiptera: Pentatomidae). Environ. Entomol. 37: $348-355$.

Nielsen A. L., Hamilton G. C., and P. W. Shearer. 2011. Seasonal phenology and monitoring of the non-native Halyomorpha halys (Stål) (Hemiptera: Pentatomidae) in soybean. Environ. Entomol. 40: 231-238.

Organic Research and Education Initiative. 2012. Whole farm organic management of BMSB and endemic Pentatomids through behavior-based habitat manipulation. USDA-NIFA OREI \# 2012-51300-20097. Rutgers Agricultural Research and Extension Center, Bridgeton, New Jersey.

Owens D.R., D.A. Herbert, G. P. Diveley, D. D. Reisig, and T. P. Kuhar. 2013. Does feeding by Halyomorpha halys (Hemiptera: Pentatomidae) reduce soybean seed quality and yield? J. Econ. Entomol. 106: 1312-1323. 
Park, Y.-L., R. K. Krell, and M. Carroll. 2007. Theory, technology, and practice of site-specific management. J. Asia-Pac. Entomol. 10: 89-101.

Park, Y.-L., and R. K. Krell. 2005. Generation of prescription maps for curative and preventative site-specific management of bean leaf beetles (Coleoptera: Chrysomelidae). J. Asia-Pac. Entomol. 8: 375-380.

Perry, J. N., L. Winder, J. M. Holland, and R. D. Alston. 1999. Red-blue dots for detecting clusters in count data. Ecol. Lett. 2: 106-113.

Reay-Jones, F. P. F. 2010. Spatial and temporal patterns of stink bugs (Hemiptera: Pentatomidae) in wheat. Environ. Entomol. 39: 944-955.

Schotzko, D. J., and L. E. O’Keeffe. 1990. Effect of sample placement on the geostatistical analysis of the spatial distribution of Lygus hesperus (Heteroptera: Miridae) in lentils. J. Econ. Entomol. 83: 1888-1900.

Strickland, R. M., D. R. Ess, and S. D. Parsons. 1998. Precision farming and precision pest management: the power of new crop production technologies. J. Nematol. 30: 431-435.

Taylor C. M., P. L. Coffey, B. D. DeLay, and G. P. Dively. 2014. The Importance of Gut Symbionts in the Development of the brown marmorated stink bug, Halyomorpha halys (Stål). PLoS ONE 9: 1-9.

Tillman, P. G., T. D. Northfield, R. F. Mizell, and T. C. Riddle. 2009. Spatiotemporal patterns and dispersal of stink bugs (Heteroptera: Pentatomidae) in peanut-cotton farmscapes. Environ. Entomol. 38: 1038-1052. 
United States Department of Agriculture, American Marketing Service. National Organic Program 7 CFR § 205.

Venugopal, P. D., H. M. Martinson, E. J. Bermann, P. M. Shrewsbury, and M. J. Raupp. 2015. Edge effects influence the abundance of the invasive Halyomorpha halys (Hemiptera: Pentatomidae) in woody plant nurseries. Environ. Entomol. 44: 474-479.

Wallner A. M., G. C. Hamilton, A. L. Nielsen, N. Hahn, E. J. Green, and C. R. Rodriguez-Saona. 2014. Landscape factors facilitating the invasive dynamics and distribution of the brown marmorated stink bug, Halyomorpha halys (Hemiptera: Pentatomidae), after arrival in the United States. PLoS ONE 9: 1-12.

Xu, J., D. M. Fonseca, G. C. Hamilton, K. A. Hoelmer, and A. L. Nielsen. 2014. Tracing the origin of US brown marmorated stink bugs, Halyomorpha halys. Biol. Invas. 16: 153-166.

Zhu G., W. Bu, Y. Gao, and G. Liu. 2012. Potential geographic distribution of brown marmorated stink bug invasion (Halyomorpha halys). PLoS ONE 7: 1-10. 


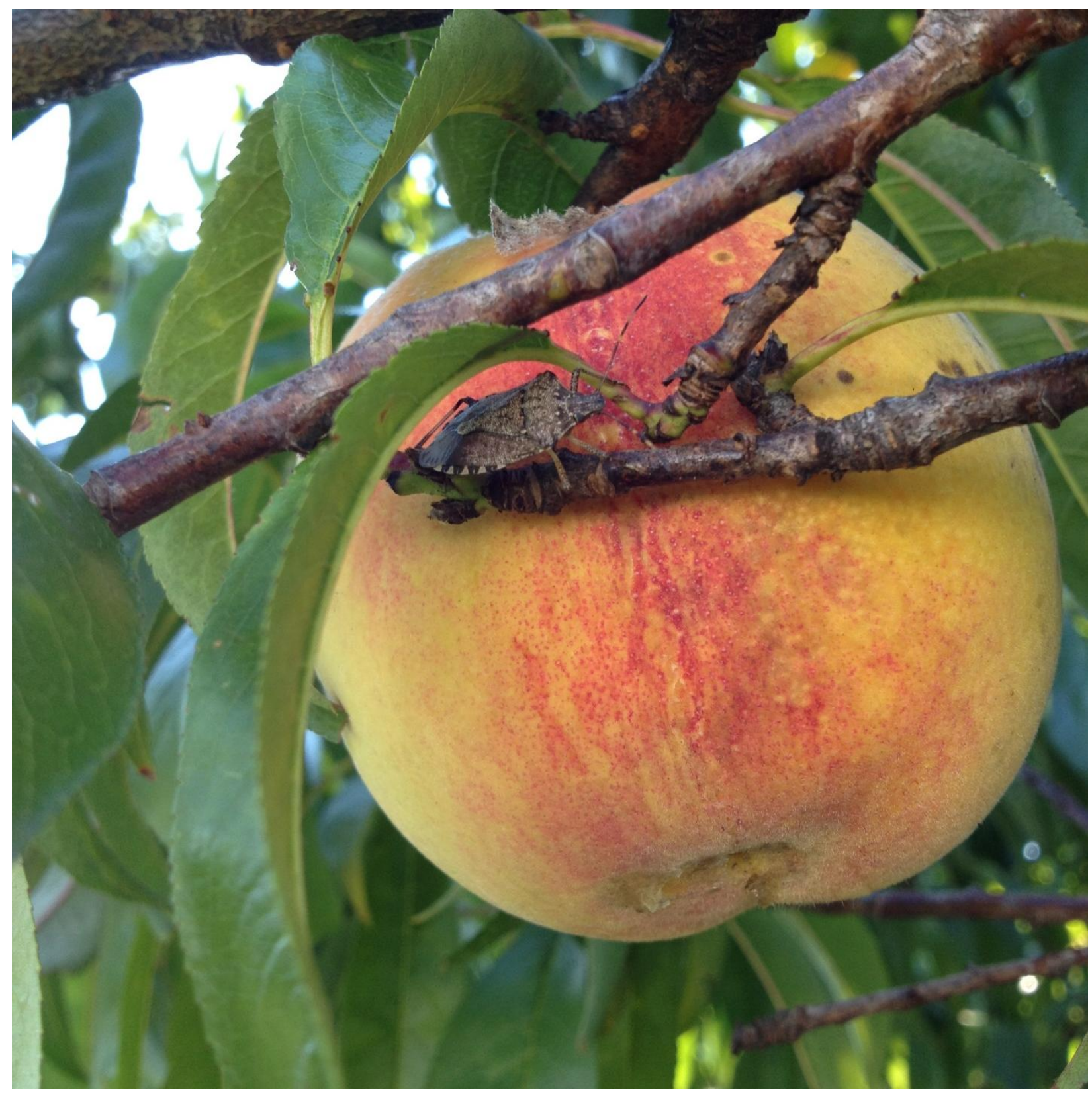

Fig. 1. Halyomorpha halys adult feeding on peach 


\title{
Chapter 2: Spatial and temporal distribution of Halyomorpha halys (Hemiptera: Pentatomidae) in organic farming systems
}

\begin{abstract}
An obstacle to efficient management of the brown marmorated stink bug, Halyomorpha halys (Hemiptera: Pentatomidae), is the lack of knowledge of its seasonal movements at the landscape level. H. halys is highly mobile and utilizes various commodities throughout the growing season, making it difficult to manage. We hypothesized that $H$. halys displayed an annual spatial pattern. We conducted a two-year spatial study on three organic farms in West Virginia and New Jersey. A total of 92-127 sample locations throughout each farm were plotted using a global positioning system and were visually surveyed for $H$. halys nymphs and adults from May through November in 2012-2014. Count data were paired with geocoordinates to perform spatial analysis by distance indices (SADIE) to characterize spatial distribution patterns and spatial associations of $H$. halys with commodities. West Virginia populations displayed two peaks (late May - early June and mid-September), while the New Jersey population displayed only one (July). Crops bearing the largest numbers of $H$. halys included pears, apples, cherries, peaches, and berries. Results indicate $H$. halys was randomly distributed over the commodity types throughout the growing season. Significant spatial patterns consisted of gaps with relatively low populations covering much of the cropping areas, and patches with relatively high populations observed on trees, wild blackberry, corn, and peppers. Gaps often coincided with apparently suitable host-plants, such as tomatoes or peppers. Positive spatial associations between years suggests that areawide pest management could be used to control populations if patches are identified.
\end{abstract}

Keywords: Halyomorpha halys, SADIE, Spatial distribution, Spatial association 
While most spatial arrangements, or patterns, are scale-dependent, many insects display some degree of aggregation (Davis 1994). An insect's spatial and temporal distributions may provide a better understanding of its role in an ecosystem. In some cases, this understanding may be used to promote the recovery of rare or valuable species. In others, it can be used by managers to help control pests from selected areas. Recent developments in advanced analytic methods including Geographical Information Systems (GIS) have enhanced the limits of spatial ecology (Park et al. 2006, Perry et al. 1999).

Site-specific integrated pest management (IPM) is the application of GIS and variable rate technology to increase the efficiency of agricultural pest management (Park et al. 2007). Treating a pest infestation on a field-by-field basis is often difficult when the pest is highly mobile, or has numerous host plants (Leskey and Hamilton 2010). This is the case with the study organism, Halyomorpha halys (Hemiptera: Pentatomidae). Nymphs are capable of walking 10 m per day to find new host plants (Lee et al. 2014), and adults have flown up to 60 $\mathrm{km}$ in flight mill tests (Lee and Leskey 2015). Additionally, H. halys has a wide host range including 169 confirmed host plants (Bergmann et al. 2014). These characteristics reduce the effectiveness of field-by-field IPM and suggest that a larger-scale approach is needed.

Areawide pest management, the hindering of key pest sources by treatment of large areas, is more appropriate for this type of insect (Park et al. 2007). The concept of areawide pest management, first proposed in the 1960s, involves the elective (or mandatory) management of large geographic areas, often by organizations, to keep source populations of pests below economic injury levels (Kogan 1998, Tollefson 1998). Areawide pest management has been explored in efforts to control numerous insects, including western corn rootworm (Coleoptera: 
Chrysomelidae), codling moth (Lepidoptera: Tortricidae), and eastern subterranean termite (Isoptera: Rhinotermitidae) (McKenzie et al. 2002, Knight 2008, Smith et al. 2006).

H. halys is a polyphytophagous insect, first recorded in the Eastern U.S. in 1996 (Hoebeke and Carter 2003). Native to China, Korea, and Japan, H. halys was most likely introduced via shipping crates. Genetic markers have identified the source of the U.S. population as Beijing, in northeastern China (Xu et al. 2013). In the decade following its introduction, the $H$. halys population grew, rapidly becoming an important agricultural and nuisance pest (Leskey et al. 2012a). Feeding damage caused by $H$. halys causes unsightly blemishes and misshapen fruit, greatly reducing the market value (Nielsen and Hamilton 2009). Typical management involves the scheduled application of broad-spectrum insecticides (Leskey et al. 2012a). Organic growers face unique challenges in the form of additional restrictions on what chemicals they may use for treatments (National Organic Program 2013). Instead, they attempt to manage pests, including $H$. halys, through biological control and crop management.

Currently growers rely on scheduled insecticide applications to combat $H$. halys because they cannot predict when or where $H$. halys will invade their orchards and fields. Several studies have examined temporal distribution within orchards (Leskey et al. 2012a and b, Krawczyk and Hul 2011, Nielsen and Hamilton 2009). However, none of these studies analyzed spatial data at the farm level. Additionally, previous studies did not consider various types of agricultural systems and crops coexisting on a farm. Research in vegetable fields has been focused on recording damage and risk potentials, and temporal distribution in specific crops (Leskey et al. 2012a, Nielsen et al. 2011, Owens et al. 2013).

The goal of this study was to characterize the spatial distribution and movement patterns of $H$. halys, and to investigate spatial relationships between the insect and the environment. This 
study was intended to provide short-term management options by determining when and where H. halys are most concentrated on the farm.

\section{Materials and Methods}

Study sites. This study was conducted on three farms in the Mid-Atlantic region of the United States of America. Farms used in this project employed highly dynamic systems of crop rotation and variation in an effort to disrupt pest habitat and encourage natural enemies. The West Virginia University Organic Farm, located in Morgantown, WV, this certified organic site encompasses $\sim 77$ acres (Fig. 1). Redbud Organic Farm, near Inwood, WV focuses on pest management through natural enemies and diverse plantings (Fig. 2). At 11 acres Redbud Organic Farm is the smallest site, yet it produces as many types of crops as the larger farms. The final site was the Muth Family Farm, in Williamstown, NJ (Fig. 3). At 108 acres, it is the largest site. All three sites were certified organic farms. They also all feature diverse, dynamic plantings, with a wide variety of crops produced each year. Populations of $H$. halys had previously been confirmed at each of these sites.

Sampling. Field sampling began in June, after crops began to grow, and concluded after two consecutive counts of zero individuals in the field. Using a sample grid is time-consuming to work with, and unnecessary for the chosen method of spatial analysis. Therefore, sample points were selected with an alternative method. All crops (commodities), were sampled for $H$. halys number. Each plot of a commodity contained at least one sample point. Single sample points were placed in the center of the plot. When plot area exceeded $60 \mathrm{~m}^{2}$, three sample points were evenly spaced throughout the plot. Plots less than $60 \mathrm{~m}^{2}$ in area contained one point. Very large plots exceeding $30,000 \mathrm{~m}^{2}$ contained more than three points. Additionally, sample points were evenly spaced around the plants bordering each farm. Each sample consisted of direct 
counting $H$. halys on host plants within a $3.14-\mathrm{m}^{2}$ circle. If it was not possible to conduct direct counting (e.g. in thick vegetation, or trees), sweep or beat net sampling replaced it. Sweep net samples were collected by sweeping a $3.14 \mathrm{~m}^{2}$ circle with an insect net (BioQuip, Rancho Dominguez, CA). Beat net samples were collected by shaking two whole branches on opposite sides of a tree onto a beating sheet (BioQuip, Rancho Dominguez, CA). Two branches amounted to approximately the same amount of surface area as the standard sample unit.

Characterization of spatial distribution. Global positioning system (GPS), GIS, and spatial analysis technologies were used to seek a pattern in $H$. halys movements across farms. Samples included number of $H$. halys adults and nymphs, commodity, and geo-coordinates. Coordinates of sample points were recorded using a differentially-corrected global positioning system (DGPS, Mobile Mapper Pro, Magellan, Santa Clara, CA). Counts were paired with geocoordinates and were spatially analyzed using spatial analysis by distance indices (SADIE) (Perry, 1995). SADIE characterizes spatial patterns by quantifying the degree of clustering within the study area using the aggregation index $I_{\mathrm{a}}$, expressed as $I_{\mathrm{a}}=D / E_{a} . D$ is the distance to regularity, or the minimum, straight-line distance samples in a study area must move to achieve a uniform spatial distribution. $D$ is calculated using the Transportation algorithm, which quantifies flows from donor samples with higher values to receiver samples with lower values (Perry et al. 1999, Kennington and Helgason 1980). $E_{a}$ is the expected mean distance to regularity. A uniform spatial pattern is represented by $I_{\mathrm{a}}<1$, while $I_{\mathrm{a}}>1$ represents a spatially aggregated pattern. $I_{\mathrm{a}}=1$ indicates a spatially random pattern (Perry et al. 1999). To determine if these aggregations consist of clusters of consistently low counts (gaps), or consistently high counts (patches), average flow distance, the straight-line distance the value of an individual sample point must be moved to achieve a uniform distribution, must be considered. This distance is 
represented by the value Yi. SADIE was used to test the null hypothesis that $H$. halys are distributed randomly among the sample points. All SADIE statistics were calculated using SADIEShell version 2.0 (Rothamsted Experimental Station, Harpenden, Herts, UK).

Spatial association analysis. SADIE was also used to measure spatial associations between sample years by comparing cluster indices for each dataset. Positive spatial associations represent patches or gaps that occur in the same location on different sample days. Patches alternating with gaps between years represent negative spatial associations. Spatial association was quantified by SADIE index $X$, the correlation coefficient between clustering indices of each dataset. When $X>0$, there is a positive spatial association. When $X<0$, there is a negative association. Random gaps or patches were represented by $X \approx 0$. We tested the null hypothesis that each dataset was random with respect to the others.

Spatial relationship between $\mathbf{H}$. halys and commodities. To determine relationships with crop type, each commodity was categorized as a member of one of ten plant families (Amaranthaceae, Amaryllidaceae, Apicaeae, Asteraceae, Brassicaceae, Cucurbitaceae, Fabaceae, Poaceae, Rosaceae, and Solanaceae), a structure, or a tree (Table 1). If the commodity did not match these categories, or was the only representative of a family, it was grouped with "others". If significant patches coincided with one of these categories, it was further inspected to determine which specific commodity was associated with the aggregation of $H$. halys. Pairing the aggregation index $I_{\mathrm{a}}$ with geo-coordinates, we used ArcGIS version 10.2 (ESRI, Redlands, CA) to create maps displaying the geographic locations of patches and gaps of $H$. halys. Patches and gaps found were compared with the categories of commodities found at the corresponding sample location.

\section{Results}


Numbers of $H$. halys declined at all sites from 2013 to 2014 (Fig. 4). H. halys was most abundant on crops at all three sites during early and late summer (Fig. 5 a-c). During the late season, $H$. halys adults moved towards overwintering sites, becoming more abundant on noncrop commodities, such as buildings (Fig. 5 a-c). In Morgantown, although both $H$. halys nymphs and adults had $I_{\mathrm{a}}>1$ in $2013-2014$, significant aggregations $(P \leq 0.05)$ were only recorded in 2014 (Tables 2-4). Likewise, significant $(P<0.05)$ aggregations of adults were only observed in 2014. In Inwood, H. halys adults displayed significant aggregations in 2013-2014 (Tables 2-4), while nymphs were only aggregated in 2014 . Williamstown adult $H$. halys were only significantly aggregated in one observation in 2014, and significant aggregations of nymphs never occurred (Tables 2-4). When counts were pooled for early (approximately June-July), mid (approximately August-early September), and late (mid-September-November) seasons, significant $(P \leq 0.05)$ aggregations in Morgantown only occurred in late 2014 (Table 5). Inwood displayed aggregations in mid and late 2013, and mid-2014. No significant aggregations occurred in Williamstown when data were pooled. $I_{\mathrm{a}}$ values for $H$. halys adults were higher than nymphs, suggesting that adults were more spatially aggregated.

H. halys counts displayed significantly $(P>0.975)$ negative association at the end of 2013 and 2014 in Morgantown (Table 6). Counts in Inwood and Williamstown, however, displayed significantly $(P<0.025)$ positive associations in 2013 and 2014. When data were pooled, significantly positive associations occurred between mid and late, and early and late 2014 in Morgantown (Table 7). Positive associations were also recorded in Inwood, between early and late 2013, and mid and late 2014. Williamstown populations were positively associated throughout 2014. 
Locations of patches and gaps were examined with maps displaying local clustering indices (Fig. 6, Appendix I). Gaps of both H. halys adults and nymphs were larger than their patches. Patches coincide with trees and shrubs. H. halys numbers were greatest in association with pomes (apples and pears), stone fruits (cherries and peaches), and berries (blackberries and raspberries) at all three sites. High numbers were also recorded on non-domesticated trees and shrubs at the West Virginia sites. Inwood experienced high numbers on row crops (corn) and okra in 2013, and legumes (black eyed peas) and solanaceous plants (peppers) in 2014.

\section{Discussion}

Numbers of H. halys declined at all sites from 2013 to 2014 (Fig. 4). This could possibly be attributed to harsh weather conditions and extended periods of extremely low temperatures during the winter of 2013-2014, as the lowest mean temperature $H$. halys survival in North America is $-17^{\circ} \mathrm{C}$ (Cira et al. 2016). There was some variation in population dynamics between each of the three sites. In Morgantown, H. halys had two peaks in the field: first in June, and then in August- September (Fig. 5 a). Field populations displayed two peaks per year in Inwood as well, with the first in late May and early June, and the second in September (Fig. 5 b). These two-peaked patterns could indicate a second generation of $H$. halys occurring in late summer. Williamstown populations did not display this two-peaked pattern. Instead, the greatest field abundances were observed in July (Fig. 5 c). During the late season, H. halys adults moved towards overwintering sites, forming aggregations on non-crop commodities, such as buildings (Fig. 5 a-c). In both Morgantown and Inwood, on-site buildings served as overwintering sites for large numbers of $H$. halys (Fig. 7). However, we were unable to discover an overwintering site in Williamstown. 
Patches and gaps of $H$. halys distributions were recorded on all farms. However, the only significant patches occurred in Inwood. In 2013, these patches were associated with trees, wild blackberry, and corn. It should be noted that this corn was left largely unharvested late into the season. In 2014, patches were associated with trees, wild blackberry, and peppers. While peppers are often the target of $H$. halys management, this was the only instance of $H$. halys presence on peppers throughout this study. All other instances of significant aggregations were gaps, located across large swathes of the farms (Appendix I). These gaps often coincide with apparently suitable host-plants, such as tomatoes, or peppers. Currently, it is unclear why such large gaps may occur in the presence of these crops.

These data may indicate that $H$. halys was not present in large numbers in the cropping areas during the seasons observed. Our observations report lower numbers from 2013 to 2014. Additionally, our work was focused on the crop plots. At each of the sites, crop plots were separated from the field edge to facilitate equipment movement. H. halys is known to exhibit an edge effect (Venugopal et al. 2015), and these lanes could have been wide enough to discourage movement into the plots. This knowledge, coupled with our observations suggests that high levels of $H$. halys damage on crops may be linked to habitat surrounding the farm area. Future research investigating $H$. halys distributions in wild, or uncultivated areas is needed to find key source populations that can be targeted by areawide pest management.

\section{Literature Cited}

Bergmann, E.J., K.M. Bernhard, G. Bernon, M. Bickerton, S. Gill, C. Gonzales, G. C. Hamilton, C. Hedstrom, K. Kamminga, C. Koplinka-Loehr, et al. 2014. Host plants of the brown marmorated stink bug in the U.S. StopBMSB.org. http://www.stopbmsb.org/where-is- 
bmsb/hostplants/Cira, T. M., R. C. Venette, J. Aigner, T. Juhar, D. E. Mullins, S. E. Gabbert, and W. D. Hutchison. 2016. Cold tolerance of Halyomorpha halys (Hemiptera: Pentatomidae) across geographic and temporal scales. Environ. Entomol. In press.

Cira, T. M., R. C. Venette, J. Aigner, T. Juhar, D. E. Mullins, S. E. Gabbert, and W. D. Hutchison. 2016. Cold tolerance of Halyomorpha halys (Hemiptera: Pentatomidae) across geographic and temporal scales. Environ. Entomol. 45: 484-491

Davis, P. M., 1994. Statistics for describing populations. In: Pedigo, L. P., Buntin, G. D. (Eds.), Handbook of Sampling Methods for Arthropods in Agriculture. CRC Press, Boca Raton, FL, pp. $33-54$

Hoebeke E., and E. C. Carter. 2003. Halyomorpha halys (Stål) (Heteroptera: Pentatomidae): A polyphagous plant pest from Asia newly detected in North America. Proc. Entomol. Soc. Wash. 105: 225-237.

Knight, A. L. 2008. Codling moth areawide integrated pest management. Pp. 159-190. Areawide pest management: Theory and Implementation. CAB International, United Kingdom.

Kogan, M., 1998. Integrated pest management: Historical perspectives and contemporary developments. Annu. Rev. Entomol. 43: 243-270

Krawczyk, G., and L. Hull. 2011. Management options for the control of brown marmorated stink bug a Pennsylvania perspective, pp. 1-5. In Penn State University Extension (eds.), Fruit times, College Park, PA.

Lee, D. H., A. L. Nielsen, and T. C. Leskey. 2014. Dispersal capacity and behavior of nymphal stages of Halyomorpha halys (Hemiptera: Pentatomidae) evaluated under laboratory and field conditions. J. Insect Behav. 27: 639-651. 
Lee, D. H., and T. C. Leskey. 2015. Flight behavior of foraging and overwintering brown marmorated stink bug, Halyomorpha halys (Hemiptera: Pentatomidae). Bul. Entomol. Res. 105: 566-573.

Leskey, T. C., and C. G. Hamilton. 2010. Brown marmorated stink bug working group meeting. http://projects.ipmcenters.org/Northeastern/FundedProjects/ReportFiles/Pship2010/Pship201 0-Leskey-ProgressReport-237195.pdf

Leskey, T. C., C. G. Hamilton, A. L. Nielsen, D. F. Polk, C. Rodriguez-Saona., J. C. Bergh, and S. E. Wright. 2012a. Pest status of the brown marmorated stink bug, Halyomorpha halys in the USA. Outl. Pest Manag. 23: 218-226.

Leskey, T. C., B. D. Short, B. R. Butler, and S. E. Wright. 2012b. Impact of the invasive brown barmorated stink bug, Halyomorpha halys (Stål), in Mid-Atlantic tree fruit orchards in the United States: Case studies of commercial management. Psyche 2012b: 1-14.

McKenzie, S. A., Wilde, G. E., and R. J. Whitworth. 2002. Areawide Management of Western corn rootworm (Coleoptera: Chrysomelidae): Impact of SLAM® on selected non-target arthropods in Kansas. J. Kansas Entomol. Soc. 75: 222-228. http://www.jstor.org/stable/25086072

National Organic Program. 2013. Organic standards. http://www.ams.usda.gov/AMSv1.0/ams.fetchTemplateData.do?template=TemplateN\&navI $\underline{\mathrm{D}=\text { OrganicStandardsLinkNOPNationalList\&rightNav1=OrganicStandardsLinkNOPNational }}$ $\underline{\text { List } \& \text { topNav }=\& l e f t N a v=\& p a g e=N O P O r g a n i c S t a n d a r d s \& r e s u l t T y p e=\& \text { acct }=\text { nopgeninfo }}$ 
Nielsen A. L., and G. C. Hamilton. 2009. Seasonal occurrence and impact of Halyomorpha halys (Hemiptera: Pentatomidae) in tree fruit. J. Econ. Entomol. 102: 1133-1140.

Nielsen A. L., Hamilton G. C., and P. W. Shearer. 2011. Seasonal phenology and monitoring of the non-native Halyomorpha halys (Stål) (Hemiptera: Pentatomidae) in soybean. Environ. Entomol. 40: 231-238.

Owens D.R., D.A. Herbert, G. P. Diveley, D. D. Reisig, and T. P. Kuhar. 2013. Does feeding by Halyomorpha halys (Hemiptera: Pentatomidae) reduce soybean seed quality and yield? J. Econ. Entomol. 106: 1312-1323.

Park, Y.-L., R. K. Krell, and M. Carroll. 2007. Theory, technology, and practice of site-specific management. J. Asia-Pac. Entomol. 10: 89-101.

Park, Y.-L., T. M. Perring, C. A. Farrar, and C. Gispert, 2006. Spatial and temporal distributions of two sympatric Homalodisca spp. (Hemiptera: Cicadellidae): Implications for areawide pest management. Ag. Ecosyst. Environ. 113: 168-174.

Perry, J. N., 1995. Spatial analysis by distance indices. J. Anim. Ecol. 64: 303-314.

Perry, J. N., L. Winder, J. M. Holland, and R. D. Alston. 1999. Red-blue dots for detecting clusters in count data. Ecol. Lett. 2: 106-113.

Smith, J., N. Y. Su, and R. N. Escobar, 2006. An areawide population management project for the invasive eastern subterranean termite (Isoptera: Rhinotermitidae) in a low-income community in Santiago, Chile. Am. Entomol. 52: 253-260 
Tollefson, J. J. 1998. Rootworm areawide management program in Iowa. J. Agric. Entomol. 15: 351-357.

United States Department of Agriculture, American Marketing Service. National Organic Program 7 CFR § 205.

Xu, J., D. M. Fonseca, G. C. Hamilton, K. A. Hoelmer, and A.L. Nielsen. 2014. Tracing the origin of US brown marmorated stink bugs, Halyomorpha halys. Biol. Invas. 16: 153-166. 
Table 1 List of types of landscape elements and corresponding land use and commodities

\begin{tabular}{|c|c|c|c|c|c|c|c|c|c|c|c|c|}
\hline Rosaceae & Cucurbitaceae & Amaranthaceae & Poaceae & Brassicaceae & Fabaceae & Asteraceae & Apiaceae & Amaryllidaceae & Solanaceae & Others & Structures & Trees \\
\hline apple & cucumber & beets & corn & bok choy & beans & artichoke & carrot & garlic & eggplant & asparagus & barn & Acer spp. \\
\hline black cherry & $\begin{array}{l}\text { cucumber/ } \\
\text { eggplant }\end{array}$ & chard & $\begin{array}{l}\text { orchard } \\
\text { grass }\end{array}$ & broccoli & $\begin{array}{l}\text { black eyed } \\
\text { peas }\end{array}$ & sunflower & dill & leek & $\begin{array}{l}\text { high-tunnel cucumber/ } \\
\text { tomato }\end{array}$ & basil & boxes & Carya spp. \\
\hline blackberry & $\begin{array}{l}\text { high tunnel } \\
\text { cucumber }\end{array}$ & quinoa & rye & cabbage & $\begin{array}{l}\text { black } \\
\text { locust }\end{array}$ & & fennel & onion & $\begin{array}{l}\text { high-tunnel pepper/ } \\
\text { tomato }\end{array}$ & black mulch & $\begin{array}{l}\text { chicken } \\
\text { coop }\end{array}$ & Illex spp. \\
\hline cherry & melon & & switchgrass & $\begin{array}{l}\text { collard } \\
\text { greens }\end{array}$ & cowpea & & & & leeks/ peppers & blueberry & greehouse & $\begin{array}{l}\text { Liriodendron } \\
\text { spp. }\end{array}$ \\
\hline fruit tree & squash & & wheat & kale & $\begin{array}{l}\text { green } \\
\text { bean }\end{array}$ & & & & pepper & flowers & jacket & Morus spp. \\
\hline $\begin{array}{l}\text { multifloral } \\
\text { rose }\end{array}$ & $\begin{array}{l}\text { squash/ } \\
\text { cucumber }\end{array}$ & & & lettuce & $\begin{array}{l}\text { high } \\
\text { tunnel } \\
\text { bean }\end{array}$ & & & & peppers & grape & $\begin{array}{l}\text { machine } \\
\text { shed }\end{array}$ & Populus spp. \\
\hline peach & squash/basil & & & radish & peas & & & & soybean/ tomato & grape/ peach & $\begin{array}{c}\text { sheep } \\
\text { shed }\end{array}$ & Quercus spp. \\
\hline pear & watermelon & & & red cabbage & soybean & & & & squash/ tomato & herbs & shop & Salix spp. \\
\hline $\begin{array}{l}\text { raspberry/ } \\
\text { blackberry }\end{array}$ & zucchini & & & & & & & & Tomatillo & mixed greens & & Tilia spp. \\
\hline rose & & & & & & & & & tomato & okra & & $\begin{array}{l}\text { unidentified } \\
\text { tree }\end{array}$ \\
\hline \multirow[t]{6}{*}{ strawberry } & & & & & & & & & Tomato/cucumber & pasture & & \\
\hline & & & & & & & & & tomato/pepper & pokeberry & & \\
\hline & & & & & & & & & & rhubarb & & \\
\hline & & & & & & & & & & seedlings & & \\
\hline & & & & & & & & & & $\begin{array}{l}\text { unidentified } \\
\text { shrub }\end{array}$ & & \\
\hline & & & & & & & & & & unplanted & & \\
\hline
\end{tabular}


Table 2. SADIE statistics for the spatial distribution of $H$. halys nymphs

\begin{tabular}{|c|c|c|c|c|c|c|}
\hline Site & Year & Date & Average & $\mathrm{SD}$ & $I_{\mathrm{a}}{ }^{\mathrm{a}}$ & $\mathrm{P}_{\mathrm{a}}$ \\
\hline Morgantown, WV & 2013 & 12-Jun & 0.04 & 0.408 & $\mathrm{n} / \mathrm{a}$ & $\mathrm{n} / \mathrm{a}$ \\
\hline Morgantown, WV & 2013 & 26-Jun & 0.05 & 0.510 & $\mathrm{n} / \mathrm{a}$ & $\mathrm{n} / \mathrm{a}$ \\
\hline Morgantown, WV & 2013 & 12-Jul & 0.01 & 0.102 & $\mathrm{n} / \mathrm{a}$ & $\mathrm{n} / \mathrm{a}$ \\
\hline Morgantown, WV & 2013 & 17-Jul & 0.34 & 2.865 & 1.27 & 0.161 \\
\hline Morgantown, WV & 2013 & 2-Aug & 0.10 & 0.393 & 1.07 & 0.333 \\
\hline Morgantown, WV & 2013 & 9-Sep & 0.02 & 0.271 & $\mathrm{n} / \mathrm{a}$ & $\mathrm{n} / \mathrm{a}$ \\
\hline Morgantown, WV & 2013 & 20-Sep & 0.01 & 0.090 & $\mathrm{n} / \mathrm{a}$ & $\mathrm{n} / \mathrm{a}$ \\
\hline Morgantown, WV & 2013 & $4-\mathrm{Oct}$ & 0.00 & $\mathrm{n} / \mathrm{a}$ & $\mathrm{n} / \mathrm{a}$ & $\mathrm{n} / \mathrm{a}$ \\
\hline Morgantown, WV & 2013 & $15-$-Oct & 0.00 & $\mathrm{n} / \mathrm{a}$ & $\mathrm{n} / \mathrm{a}$ & $\mathrm{n} / \mathrm{a}$ \\
\hline Morgantown, WV & 2013 & 29-Oct & 0.00 & $\mathrm{n} / \mathrm{a}$ & $\mathrm{n} / \mathrm{a}$ & $\mathrm{n} / \mathrm{a}$ \\
\hline Morgantown, WV & 2013 & 5-Nov & 0.00 & $\mathrm{n} / \mathrm{a}$ & $\mathrm{n} / \mathrm{a}$ & $\mathrm{n} / \mathrm{a}$ \\
\hline Morgantown, WV & 2014 & 6-Jun & 0.00 & $\mathrm{n} / \mathrm{a}$ & $\mathrm{n} / \mathrm{a}$ & $\mathrm{n} / \mathrm{a}$ \\
\hline Morgantown, WV & 2014 & 21-Jun & 0.00 & $\mathrm{n} / \mathrm{a}$ & $\mathrm{n} / \mathrm{a}$ & $\mathrm{n} / \mathrm{a}$ \\
\hline Morgantown, WV & 2014 & 1-Jul & 0.01 & 0.115 & 1.34 & 0.149 \\
\hline Morgantown, WV & 2014 & 31-Jul & 0.01 & 0.115 & 1.63 & 0.025 \\
\hline Morgantown, WV & 2014 & 14-Aug & 0.03 & 0.337 & 1.06 & 0.327 \\
\hline Morgantown, WV & 2014 & 26-Aug & 0.05 & 0.364 & 1.98 & 0.003 \\
\hline Morgantown, WV & 2014 & 9-Sep & 0.01 & 0.115 & 0.88 & 0.600 \\
\hline Morgantown, WV & 2014 & 25-Sep & 0.00 & $\mathrm{n} / \mathrm{a}$ & $\mathrm{n} / \mathrm{a}$ & $\mathrm{n} / \mathrm{a}$ \\
\hline Morgantown, WV & 2014 & 9-Oct & 0.00 & $\mathrm{n} / \mathrm{a}$ & $\mathrm{n} / \mathrm{a}$ & $\mathrm{n} / \mathrm{a}$ \\
\hline Morgantown, WV & 2014 & 21-Oct & 0.00 & $\mathrm{n} / \mathrm{a}$ & $\mathrm{n} / \mathrm{a}$ & $\mathrm{n} / \mathrm{a}$ \\
\hline Inwood, WV & 2013 & 22-May & 0.00 & $\mathrm{n} / \mathrm{a}$ & $\mathrm{n} / \mathrm{a}$ & $\mathrm{n} / \mathrm{a}$ \\
\hline Inwood, WV & 2013 & 8-Jul & 0.11 & 0.671 & 0.97 & 0.504 \\
\hline Inwood, WV & 2013 & 23-Jul & 0.00 & $\mathrm{n} / \mathrm{a}$ & 1.31 & 0.084 \\
\hline Inwood, WV & 2013 & 3-Sep & 0.05 & 0.374 & $\mathrm{n} / \mathrm{a}$ & $\mathrm{n} / \mathrm{a}$ \\
\hline Inwood, WV & 2013 & 17-Sep & 0.01 & 0.104 & $\mathrm{n} / \mathrm{a}$ & $\mathrm{n} / \mathrm{a}$ \\
\hline Inwood, WV & 2013 & $1-\mathrm{Oct}$ & 0.00 & $\mathrm{n} / \mathrm{a}$ & $\mathrm{n} / \mathrm{a}$ & $\mathrm{n} / \mathrm{a}$ \\
\hline Inwood, WV & 2013 & 18 -Oct & 0.00 & $\mathrm{n} / \mathrm{a}$ & $\mathrm{n} / \mathrm{a}$ & $\mathrm{n} / \mathrm{a}$ \\
\hline Inwood, WV & 2013 & 1-Nov & 0.00 & $\mathrm{n} / \mathrm{a}$ & $\mathrm{n} / \mathrm{a}$ & $\mathrm{n} / \mathrm{a}$ \\
\hline Inwood, WV & 2013 & 25-Nov & 0.00 & $\mathrm{n} / \mathrm{a}$ & $\mathrm{n} / \mathrm{a}$ & $\mathrm{n} / \mathrm{a}$ \\
\hline Inwood, WV & 2014 & 4-Jun & 0.00 & $\mathrm{n} / \mathrm{a}$ & $\mathrm{n} / \mathrm{a}$ & $\mathrm{n} / \mathrm{a}$ \\
\hline Inwood, WV & 2014 & 24-Jun & 0.00 & $\mathrm{n} / \mathrm{a}$ & $\mathrm{n} / \mathrm{a}$ & $\mathrm{n} / \mathrm{a}$ \\
\hline Inwood, WV & 2014 & 1-Jul & 0.01 & 0.114 & 0.79 & 0.892 \\
\hline Inwood, WV & 2014 & 27-Aug & 0.05 & 0.426 & 1.47 & 0.019 \\
\hline Inwood, WV & 2014 & 10-Sep & 0.16 & 0.673 & 1.41 & 0.043 \\
\hline Inwood, WV & 2014 & 24-Sep & 0.02 & 0.139 & 1.11 & 0.268 \\
\hline Inwood, WV & 2014 & 8-Oct & 0.00 & $\mathrm{n} / \mathrm{a}$ & $\mathrm{n} / \mathrm{a}$ & $\mathrm{n} / \mathrm{a}$ \\
\hline Inwood, WV & 2014 & 23-Oct & 0.00 & $\mathrm{n} / \mathrm{a}$ & $\mathrm{n} / \mathrm{a}$ & $\mathrm{n} / \mathrm{a}$ \\
\hline Inwood, WV & 2014 & 7-Nov & 0.00 & $\mathrm{n} / \mathrm{a}$ & $\mathrm{n} / \mathrm{a}$ & $\mathrm{n} / \mathrm{a}$ \\
\hline Williamstown, NJ & 2013 & 10-Jul & 0.30 & 2.627 & 0.84 & 0.668 \\
\hline Williamstown, NJ & 2013 & 24-Jul & 0.34 & 2.655 & 1.40 & 0.076 \\
\hline Williamstown, NJ & 2013 & 7-Aug & 0.24 & 0.940 & 0.83 & 0.743 \\
\hline Williamstown, NJ & 2013 & 21-Aug & 0.16 & 0.669 & 0.76 & 0.892 \\
\hline Williamstown, NJ & 2013 & 4-Sep & 0.09 & 0.321 & 1.10 & 0.266 \\
\hline Williamstown, NJ & 2013 & 18-Sep & 0.00 & $\mathrm{n} / \mathrm{a}$ & $\mathrm{n} / \mathrm{a}$ & $\mathrm{n} / \mathrm{a}$ \\
\hline Williamstown, NJ & 2013 & 2-Oct & 0.00 & $\mathrm{n} / \mathrm{a}$ & $\mathrm{n} / \mathrm{a}$ & $\mathrm{n} / \mathrm{a}$ \\
\hline Williamstown, NJ & 2014 & 13-Jun & 0.01 & 0.085 & $\mathrm{n} / \mathrm{a}$ & $\mathrm{n} / \mathrm{a}$ \\
\hline Williamstown, NJ & 2014 & 27-Jun & 0.01 & 0.085 & $\mathrm{n} / \mathrm{a}$ & $\mathrm{n} / \mathrm{a}$ \\
\hline Williamstown, NJ & 2014 & 10-Jul & 0.03 & 0.341 & $\mathrm{n} / \mathrm{a}$ & $\mathrm{n} / \mathrm{a}$ \\
\hline Williamstown, NJ & 2014 & 25-Jul & 0.01 & 0.120 & 0.77 & 0.863 \\
\hline Williamstown, NJ & 2014 & 8-Aug & 0.01 & 0.170 & $\mathrm{n} / \mathrm{a}$ & $\mathrm{n} / \mathrm{a}$ \\
\hline Williamstown, NJ & 2014 & 22-Aug & 0.00 & $\mathrm{n} / \mathrm{a}$ & 1.06 & 0.320 \\
\hline Williamstown, NJ & 2014 & 11-Sep & 0.00 & $\mathrm{n} / \mathrm{a}$ & $\mathrm{n} / \mathrm{a}$ & $\mathrm{n} / \mathrm{a}$ \\
\hline Williamstown, NJ & 2014 & 29-Sep & 0.00 & $\mathrm{n} / \mathrm{a}$ & $\mathrm{n} / \mathrm{a}$ & $\mathrm{n} / \mathrm{a}$ \\
\hline
\end{tabular}

${ }^{\mathrm{a}}$ Overall degree of clustering $\left(I_{\mathrm{a}}\right)$ with its associated $P$ value $\left(P_{\mathrm{a}}\right)$ in parenthesis. $I_{\mathrm{a}}=1$ suggests a random, $I_{\mathrm{a}}>1$ suggests an aggregated, and $I_{\mathrm{a}}<1$ suggests a regular spatial pattern. Significant $(P<0.05)$ associations are in bold. $\mathrm{n} / \mathrm{a}$ listed when SADIE could not be conducted ( 0 individuals found). 
Table 3. SADIE statistics for the spatial distribution of $H$. halys adults

\begin{tabular}{|c|c|c|c|c|c|c|}
\hline Site & Year & Date & Average & $\mathrm{SD}$ & $I_{\mathrm{a}}{ }^{\mathrm{a}}$ & $\mathrm{P}_{\mathrm{a}}$ \\
\hline Morgantown, WV & 2013 & 12-Jun & 0.12 & 0.565 & 0.94 & 0.488 \\
\hline Morgantown, WV & 2013 & 26-Jun & 0.07 & 0.417 & 1.44 & 0.080 \\
\hline Morgantown, WV & 2013 & 12-Jul & 0.00 & $\mathrm{n} / \mathrm{a}$ & $\mathrm{n} / \mathrm{a}$ & $\mathrm{n} / \mathrm{a}$ \\
\hline Morgantown, WV & 2013 & 17-Jul & 0.02 & 0.144 & 1.28 & 0.163 \\
\hline Morgantown, WV & 2013 & 2-Aug & 0.04 & 0.371 & 1.10 & 0.304 \\
\hline Morgantown, WV & 2013 & 9-Sep & 0.07 & 0.428 & 0.92 & 0.547 \\
\hline Morgantown, WV & 2013 & 20-Sep & 0.16 & 0.800 & 1.13 & 0.282 \\
\hline Morgantown, WV & 2013 & 4-Oct & 0.01 & 0.098 & 0.86 & 0.637 \\
\hline Morgantown, WV & 2013 & 15-Oct & 0.01 & 0.101 & 1.03 & 0.395 \\
\hline Morgantown, WV & 2013 & 29-Oct & 0.01 & 0.151 & $\mathrm{n} / \mathrm{a}$ & $\mathrm{n} / \mathrm{a}$ \\
\hline Morgantown, WV & 2013 & 5-Nov & 0.02 & 0.274 & $\mathrm{n} / \mathrm{a}$ & $\mathrm{n} / \mathrm{a}$ \\
\hline Morgantown, WV & 2014 & 6-Jun & 0.08 & 0.532 & 0.98 & 0.463 \\
\hline Morgantown, WV & 2014 & 21-Jun & 0.02 & 0.180 & $\mathrm{n} / \mathrm{a}$ & $\mathrm{n} / \mathrm{a}$ \\
\hline Morgantown, WV & 2014 & 1-Jul & 0.01 & 0.090 & 1.34 & 0.133 \\
\hline Morgantown, WV & 2014 & 31-Jul & 0.02 & 0.127 & 1.75 & 0.016 \\
\hline Morgantown, WV & 2014 & 14-Aug & 0.02 & 0.127 & 0.99 & 0.422 \\
\hline Morgantown, WV & 2014 & 26-Aug & 0.04 & 0.371 & 1.80 & 0.006 \\
\hline Morgantown, WV & 2014 & 9-Sep & 0.12 & 0.505 & 1.68 & 0.026 \\
\hline Morgantown, WV & 2014 & 25-Sep & 0.11 & 0.569 & 2.44 & $\mathrm{n} / \mathrm{a}$ \\
\hline Morgantown, WV & 2014 & 9-Oct & 0.01 & 0.108 & $\mathrm{n} / \mathrm{a}$ & $\mathrm{n} / \mathrm{a}$ \\
\hline Morgantown, WV & 2014 & 21-Oct & 0.01 & 0.090 & $\mathrm{n} / \mathrm{a}$ & $\mathrm{n} / \mathrm{a}$ \\
\hline Inwood, WV & 2013 & 22-May & 0.26 & 1.730 & 1.67 & 0.001 \\
\hline Inwood, WV & 2013 & 8-Jul & 0.01 & 0.104 & $\mathrm{n} / \mathrm{a}$ & $\mathrm{n} / \mathrm{a}$ \\
\hline Inwood, WV & 2013 & 23-Jul & 0.11 & 1.043 & $\mathrm{n} / \mathrm{a}$ & $\mathrm{n} / \mathrm{a}$ \\
\hline Inwood, WV & 2013 & 3-Sep & 0.28 & 0.941 & 1.49 & 0.024 \\
\hline Inwood, WV & 2013 & 17-Sep & 0.34 & 1.030 & 1.52 & 0.019 \\
\hline Inwood, WV & 2013 & $1-$ Oct & 0.21 & 0.731 & 1.12 & 0.250 \\
\hline Inwood, WV & 2013 & 18-Oct & 0.00 & $\mathrm{n} / \mathrm{a}$ & $\mathrm{n} / \mathrm{a}$ & $\mathrm{n} / \mathrm{a}$ \\
\hline Inwood, WV & 2013 & 1-Nov & 0.11 & 0.719 & 1.63 & 0.001 \\
\hline Inwood, WV & 2013 & 25-Nov & 0.11 & 0.945 & 1.44 & 0.005 \\
\hline Inwood, WV & 2014 & 4-Jun & 0.03 & 0.199 & 1.16 & 0.197 \\
\hline Inwood, WV & 2014 & 24-Jun & 0.00 & $\mathrm{n} / \mathrm{a}$ & $\mathrm{n} / \mathrm{a}$ & $\mathrm{n} / \mathrm{a}$ \\
\hline Inwood, WV & 2014 & 1-Jul & 0.00 & $\mathrm{n} / \mathrm{a}$ & $\mathrm{n} / \mathrm{a}$ & $\mathrm{n} / \mathrm{a}$ \\
\hline Inwood, WV & 2014 & 27-Aug & 0.00 & $\mathrm{n} / \mathrm{a}$ & $\mathrm{n} / \mathrm{a}$ & $\mathrm{n} / \mathrm{a}$ \\
\hline Inwood, WV & 2014 & 10-Sep & 0.27 & 1.339 & 1.42 & 0.032 \\
\hline Inwood, WV & 2014 & 24-Sep & 0.10 & 0.497 & 1.75 & 0.004 \\
\hline Inwood, WV & 2014 & $8-O c t$ & 0.05 & 0.500 & 1.38 & 0.032 \\
\hline Inwood, WV & 2014 & 23-Oct & 0.05 & 0.667 & 1.31 & 0.046 \\
\hline Inwood, WV & 2014 & 7-Nov & 0.07 & 0.821 & $\mathrm{n} / \mathrm{a}$ & $\mathrm{n} / \mathrm{a}$ \\
\hline Williamstown, NJ & 2013 & 10-Jul & 0.13 & 0.427 & 1.04 & 0.342 \\
\hline Williamstown, NJ & 2013 & 24-Jul & 0.18 & 0.825 & 0.94 & 0.516 \\
\hline Williamstown, NJ & 2013 & 7-Aug & 0.09 & 0.414 & 1.07 & 0.308 \\
\hline Williamstown, NJ & 2013 & 21-Aug & 0.06 & 0.275 & 0.90 & 0.616 \\
\hline Williamstown, NJ & 2013 & 4-Sep & 0.10 & 0.496 & 0.97 & 0.475 \\
\hline Williamstown, NJ & 2013 & 18-Sep & 0.09 & 0.321 & 1.06 & 0.318 \\
\hline Williamstown, NJ & 2013 & $2-\mathrm{Oct}$ & 0.02 & 0.147 & 1.22 & 0.150 \\
\hline Williamstown, NJ & 2014 & 13-Jun & 0.04 & 0.292 & 1.62 & 0.032 \\
\hline Williamstown, NJ & 2014 & 27-Jun & 0.02 & 0.188 & 1.15 & 0.2284 \\
\hline Williamstown, NJ & 2014 & 10-Jul & 0.03 & 0.207 & 1.011 & 0.3724 \\
\hline Williamstown, NJ & 2014 & 25-Jul & 0.04 & 0.360 & 1.065 & 0.3007 \\
\hline Williamstown, NJ & 2014 & 8-Aug & 0.03 & 0.207 & 0.839 & 0.7295 \\
\hline Williamstown, NJ & 2014 & 22-Aug & 0.04 & 0.223 & 1.055 & 0.3199 \\
\hline Williamstown, NJ & 2014 & 11-Sep & 0.01 & 0.099 & 1.127 & 0.2474 \\
\hline Williamstown, NJ & 2014 & 29-Sep & 0.03 & 0.219 & $\mathrm{n} / \mathrm{a}$ & $\mathrm{n} / \mathrm{a}$ \\
\hline
\end{tabular}

${ }^{a}$ Overall degree of clustering $\left(I_{\mathrm{a}}\right)$ with its associated $P$ value $\left(P_{\mathrm{a}}\right)$ in parenthesis. $I_{\mathrm{a}}=1$ suggests a random, $I_{\mathrm{a}}>1$ suggests an aggregated, and $I_{\mathrm{a}}<1$ suggests a regular spatial pattern. Significant $(P<0.05)$ associations are in bold. $\mathrm{n} / \mathrm{a}$ listed when SADIE could not be conducted (0 individuals found). 
Table 4. SADIE statistics for the spatial distribution of total H. halys

\begin{tabular}{|c|c|c|c|c|c|c|}
\hline Site & Year & Date & Average & $\mathrm{SD}$ & $I_{\mathrm{a}}{ }^{\mathrm{a}}$ & $\mathrm{P}_{\mathrm{a}}$ \\
\hline Morgantown, WV & 2013 & 12-Jun & 0.16 & 0.689 & 0.94 & 0.488 \\
\hline Morgantown, WV & 2013 & 26-Jun & 0.13 & 0.653 & 1.44 & 0.080 \\
\hline Morgantown, WV & 2013 & 12-Jul & 0.01 & 0.102 & $\mathrm{n} / \mathrm{a}$ & $\mathrm{n} / \mathrm{a}$ \\
\hline Morgantown, WV & 2013 & 17-Jul & 0.36 & 2.967 & 1.28 & 0.163 \\
\hline Morgantown, WV & 2013 & 2-Aug & 0.14 & 0.591 & 1.10 & 0.304 \\
\hline Morgantown, WV & 2013 & 9-Sep & 0.10 & 0.633 & 0.92 & 0.547 \\
\hline Morgantown, WV & 2013 & 20-Sep & 0.16 & 0.823 & 1.13 & 0.282 \\
\hline Morgantown, WV & 2013 & 4-Oct & 0.01 & 0.098 & 0.86 & 0.637 \\
\hline Morgantown, WV & 2013 & 15 -Oct & 0.01 & 0.101 & 1.03 & 0.395 \\
\hline Morgantown, WV & 2013 & 29-Oct & 0.01 & 0.151 & $\mathrm{n} / \mathrm{a}$ & $\mathrm{n} / \mathrm{a}$ \\
\hline Morgantown, WV & 2013 & 5-Nov & 0.02 & 0.274 & $\mathrm{n} / \mathrm{a}$ & $\mathrm{n} / \mathrm{a}$ \\
\hline Morgantown, WV & 2014 & 6-Jun & 0.08 & 0.532 & 0.98 & 0.463 \\
\hline Morgantown, WV & 2014 & 21-Jun & 0.02 & 0.180 & $\mathrm{n} / \mathrm{a}$ & $\mathrm{n} / \mathrm{a}$ \\
\hline Morgantown, WV & 2014 & 1-Jul & 0.02 & 0.155 & 1.34 & 0.133 \\
\hline Morgantown, WV & 2014 & 31-Jul & 0.03 & 0.178 & 1.75 & 0.016 \\
\hline Morgantown, WV & 2014 & 14-Aug & 0.02 & 0.155 & 0.99 & 0.422 \\
\hline Morgantown, WV & 2014 & 26-Aug & 0.11 & 0.745 & 1.80 & 0.006 \\
\hline Morgantown, WV & 2014 & 9-Sep & 0.13 & 0.511 & 1.68 & 0.026 \\
\hline Morgantown, WV & 2014 & 25-Sep & 0.11 & 0.569 & 2.44 & 0.000 \\
\hline Morgantown, WV & 2014 & 9-Oct & 0.01 & 0.108 & $\mathrm{n} / \mathrm{a}$ & $\mathrm{n} / \mathrm{a}$ \\
\hline Morgantown, WV & 2014 & 21-Oct & 0.01 & 0.090 & $\mathrm{n} / \mathrm{a}$ & $\mathrm{n} / \mathrm{a}$ \\
\hline Inwood, WV & 2013 & 22-May & 0.26 & 1.730 & 1.67 & 0.001 \\
\hline Inwood, WV & 2013 & 8-Jul & 0.12 & 0.677 & 1.03 & 0.390 \\
\hline Inwood, WV & 2013 & 23-Jul & 0.11 & 1.043 & $\mathrm{n} / \mathrm{a}$ & $\mathrm{n} / \mathrm{a}$ \\
\hline Inwood, WV & 2013 & 3-Sep & 0.34 & 1.234 & 1.52 & 0.016 \\
\hline Inwood, WV & 2013 & 17-Sep & 0.35 & 1.052 & 1.54 & 0.019 \\
\hline Inwood, WV & 2013 & $1-O c t$ & 0.21 & 0.731 & 1.12 & 0.250 \\
\hline Inwood, WV & 2013 & 18 -Oct & 0.00 & 0.000 & $\mathrm{n} / \mathrm{a}$ & $\mathrm{n} / \mathrm{a}$ \\
\hline Inwood, WV & 2013 & 1-Nov & 0.11 & 0.719 & 1.63 & 0.001 \\
\hline Inwood, WV & 2013 & 25-Nov & 0.11 & 0.945 & 1.44 & 0.005 \\
\hline Inwood, WV & 2014 & 4-Jun & 0.03 & 0.199 & 1.16 & 0.197 \\
\hline Inwood, WV & 2014 & 24-Jun & 0.00 & 0.000 & $\mathrm{n} / \mathrm{a}$ & $\mathrm{n} / \mathrm{a}$ \\
\hline Inwood, WV & 2014 & 1-Jul & 0.01 & 0.114 & 0.79 & 0.892 \\
\hline Inwood, WV & 2014 & 27-Aug & 0.05 & 0.426 & 1.47 & 0.019 \\
\hline Inwood, WV & 2014 & 10-Sep & 0.44 & 1.870 & 1.47 & 0.028 \\
\hline Inwood, WV & 2014 & 24-Sep & 0.12 & 0.562 & 1.46 & $\mathbf{0 . 0 3 3}$ \\
\hline Inwood, WV & 2014 & 8-Oct & 0.05 & 0.500 & 1.38 & 0.032 \\
\hline Inwood, WV & 2014 & 23-Oct & 0.05 & 0.667 & 1.31 & 0.046 \\
\hline Inwood, WV & 2014 & 7-Nov & 0.07 & 0.821 & $\mathrm{n} / \mathrm{a}$ & $\mathrm{n} / \mathrm{a}$ \\
\hline Williamstown, NJ & 2013 & 10-Jul & 0.43 & 2.646 & 0.96 & 0.439 \\
\hline Williamstown, NJ & 2013 & 24-Jul & 0.52 & 2.758 & 1.34 & 0.098 \\
\hline Williamstown, NJ & 2013 & 7-Aug & 0.33 & 1.049 & 0.79 & 0.856 \\
\hline Williamstown, NJ & 2013 & 21-Aug & 0.37 & 1.554 & 0.80 & 0.808 \\
\hline Williamstown, NJ & 2013 & 4-Sep & 0.27 & 0.817 & 1.10 & 0.268 \\
\hline Williamstown, NJ & 2013 & 18-Sep & 0.09 & 0.321 & 1.06 & 0.318 \\
\hline Williamstown, NJ & 2013 & 2-Oct & 0.02 & 0.147 & 1.22 & 0.150 \\
\hline Williamstown, NJ & 2014 & 13-Jun & 0.05 & 0.303 & 1.55 & 0.038 \\
\hline Williamstown, NJ & 2014 & 27-Jun & 0.03 & 0.206 & 1.04 & 0.338 \\
\hline Williamstown, NJ & 2014 & 10-Jul & 0.06 & 0.396 & 1.21 & 0.163 \\
\hline Williamstown, NJ & 2014 & 25-Jul & 0.06 & 0.396 & 1.11 & 0.253 \\
\hline Williamstown, NJ & 2014 & 8-Aug & 0.05 & 0.279 & 0.75 & 0.923 \\
\hline Williamstown, NJ & 2014 & 22-Aug & 0.04 & 0.223 & 1.06 & 0.320 \\
\hline Williamstown, NJ & 2014 & 11-Sep & 0.01 & 0.099 & $\mathrm{n} / \mathrm{a}$ & $\mathrm{n} / \mathrm{a}$ \\
\hline Williamstown, NJ & 2014 & 29-Sep & 0.03 & 0.219 & 1.13 & 0.247 \\
\hline
\end{tabular}

${ }^{\mathrm{a}}$ Overall degree of clustering $\left(I_{\mathrm{a}}\right)$ with its associated $P$ value $\left(P_{\mathrm{a}}\right)$ in parenthesis. $I_{\mathrm{a}}=1$ suggests a random, $I_{\mathrm{a}}>1$ suggests an aggregated, and $I_{\mathrm{a}}<1$ suggests a regular spatial pattern. Significant $(P<0.05)$ associations are in bold. $\mathrm{n} / \mathrm{a}$ listed when SADIE could not be conducted ( 0 individuals found). 
Table 5. SADIE statistics for the spatial distribution of total $H$. halys in early, mid, and late seasons

\begin{tabular}{llllllll}
\hline \hline & & & & Total & Total & Total & Total \\
Site & Year & Seasons & Dates & Density & S. E. & $I_{\mathrm{a}}{ }^{{ }^{a}}$ & $\mathrm{P}_{\mathrm{t}}$ \\
\hline Morgantown, WV & 2013 & Early & 12-Jun - 17-Jul & 5.78 & 11.120 & 1.37 & 0.090 \\
Morgantown, WV & 2013 & Mid & 2-Aug - 4-Oct & 4.60 & 5.912 & 0.66 & 0.956 \\
Morgantown, WV & 2013 & Late & 15-Oct - 5-Nov & 0.57 & 1.579 & 1.16 & 0.190 \\
Morgantown, WV & 2014 & Early & 6-Jun - 1-Jul & 1.20 & 1.674 & 0.92 & 0.541 \\
Morgantown, WV & 2014 & Mid & 31-Jul - 9-Sep & 4.17 & 6.464 & 1.20 & 0.219 \\
Morgantown, WV & 2014 & Late & 25-Sep - 21-Oct & 1.26 & 2.643 & $\mathbf{2 . 1 3}$ & $\mathbf{0 . 0 0 1}$ \\
Inwood, WV & 2013 & Early & 22-May - 23-Jul & 4.50 & 5.893 & 1.39 & 0.050 \\
Inwood, WV & 2013 & Mid & 3-Sep - 1-Oct & 7.73 & 10.565 & $\mathbf{1 . 6 5}$ & $\mathbf{0 . 0 1 1}$ \\
Inwood, WV & 2013 & Late & 18-Oct - 18-Nov & 2.09 & 6.300 & $\mathbf{1 . 5 3}$ & $\mathbf{0 . 0 0 2}$ \\
Inwood, WV & 2014 & Early & 4-Jun - 1-Jul & 0.70 & 1.567 & 1.16 & 0.190 \\
Inwood, WV & 2014 & Mid & 27-Aug - 24-Sep & 9.40 & 17.057 & $\mathbf{1 . 7 4}$ & $\mathbf{0 . 0 0 3}$ \\
Inwood, WV & 2014 & Late & 8-Oct - 7-Nov & 3.10 & 9.110 & 1.30 & 0.056 \\
Williamstown, NJ & 2013 & Early & 10-Jul - 7-Aug & 9.00 & 11.965 & 1.12 & 0.241 \\
Williamstown, NJ & 2013 & Mid & 21-Aug - 18-Sep & 6.60 & 9.143 & 0.89 & 0.636 \\
Williamstown, NJ & 2013 & Late & 2-Oct & 0.43 & 0.787 & 1.22 & 0.150 \\
Williamstown, NJ & 2014 & Early & 13-Jun - 10-Jul & 1.73 & 3.409 & 1.27 & 0.125 \\
Williamstown, NJ & 2014 & Mid & 25-Jul - 11-Sep & 1.91 & 3.081 & 1.03 & 0.364 \\
Williamstown, NJ & 2014 & Late & 29-Sep & 0.33 & 0.707 & 1.23 & 0.166 \\
\hline Index of association $(X)$ with its associated $P$ value $\left(P_{\mathrm{t}}\right)$ in parenthesis. For a two-tail test at $95 \%$ confidence level, $P_{\mathrm{t}}$ \\
< 0.025 indicates significant positive association and $P_{\mathrm{t}}>$ 0.975 indicates significant negative association. \\
Significant associations are in bold
\end{tabular}


Table 6. Spatial association of $H$. halys nymphs, adults, and totals within years

\begin{tabular}{|c|c|c|c|c|c|c|c|c|}
\hline Site & Year & Week & $\begin{array}{l}\text { Nymphs } \\
X^{\mathrm{a}}\end{array}$ & $\begin{array}{l}\text { Nymphs } \\
\mathrm{P}\end{array}$ & $\begin{array}{l}\text { Adults } \\
X^{\mathrm{a}}\end{array}$ & $\begin{array}{l}\text { Adults } \\
\mathrm{P}\end{array}$ & $\begin{array}{l}\text { Total } \\
X^{\mathrm{a}} \\
\end{array}$ & $\begin{array}{l}\text { Total } \\
\mathrm{P}_{\mathrm{t}}\end{array}$ \\
\hline Morgantown, WV & 2013 & 1,2 & $\mathrm{n} / \mathrm{a}$ & $\mathrm{n} / \mathrm{a}$ & -0.10 & 0.772 & -0.10 & 0.772 \\
\hline Morgantown, WV & 2013 & 2,3 & $\mathrm{n} / \mathrm{a}$ & $\mathrm{n} / \mathrm{a}$ & $\mathrm{n} / \mathrm{a}$ & $\mathrm{n} / \mathrm{a}$ & $\mathrm{n} / \mathrm{a}$ & $\mathrm{n} / \mathrm{a}$ \\
\hline Morgantown, WV & 2013 & 3,4 & $\mathrm{n} / \mathrm{a}$ & $\mathrm{n} / \mathrm{a}$ & $\mathrm{n} / \mathrm{a}$ & $\mathrm{n} / \mathrm{a}$ & $\mathrm{n} / \mathrm{a}$ & $\mathrm{n} / \mathrm{a}$ \\
\hline Morgantown, WV & 2013 & 4,5 & -0.27 & 0.992 & -0.19 & 0.955 & -0.19 & 0.955 \\
\hline Morgantown, WV & 2013 & 5,6 & $\mathrm{n} / \mathrm{a}$ & $\mathrm{n} / \mathrm{a}$ & 0.08 & 0.286 & 0.08 & 0.286 \\
\hline Morgantown, WV & 2013 & 6,7 & $\mathrm{n} / \mathrm{a}$ & $\mathrm{n} / \mathrm{a}$ & -0.59 & $>.9999$ & -0.59 & $>.9999$ \\
\hline Morgantown, WV & 2013 & 7,8 & $\mathrm{n} / \mathrm{a}$ & $\mathrm{n} / \mathrm{a}$ & -0.54 & $>.9999$ & -0.54 & $>.9999$ \\
\hline Morgantown, WV & 2013 & 8,9 & $\mathrm{n} / \mathrm{a}$ & $\mathrm{n} / \mathrm{a}$ & -0.59 & $>.9999$ & -0.59 & $>.9999$ \\
\hline Morgantown, WV & 2013 & 9,10 & $\mathrm{n} / \mathrm{a}$ & $\mathrm{n} / \mathrm{a}$ & $\mathrm{n} / \mathrm{a}$ & $\mathrm{n} / \mathrm{a}$ & $\mathrm{n} / \mathrm{a}$ & $\mathrm{n} / \mathrm{a}$ \\
\hline Morgantown, WV & 2014 & 1,2 & $\mathrm{n} / \mathrm{a}$ & $\mathrm{n} / \mathrm{a}$ & $\mathrm{n} / \mathrm{a}$ & $\mathrm{n} / \mathrm{a}$ & $\mathrm{n} / \mathrm{a}$ & $\mathrm{n} / \mathrm{a}$ \\
\hline Morgantown, WV & 2014 & 2,3 & $\mathrm{n} / \mathrm{a}$ & $\mathrm{n} / \mathrm{a}$ & $\mathrm{n} / \mathrm{a}$ & $\mathrm{n} / \mathrm{a}$ & $\mathrm{n} / \mathrm{a}$ & $\mathrm{n} / \mathrm{a}$ \\
\hline Morgantown, WV & 2014 & 3,4 & 0.034 & 0.411 & 0.48 & 0.005 & 0.48 & 0.005 \\
\hline Morgantown, WV & 2014 & 4,5 & -0.34 & 0.998 & -0.08 & 0.695 & -0.08 & 0.695 \\
\hline Morgantown, WV & 2014 & 5,6 & -0.44 & 1.000 & -0.39 & 0.999 & -0.39 & 0.999 \\
\hline Morgantown, WV & 2014 & 6,7 & -0.22 & 0.915 & 0.16 & 0.101 & 0.16 & 0.101 \\
\hline Morgantown, WV & 2014 & 7,8 & $\mathrm{n} / \mathrm{a}$ & $\mathrm{n} / \mathrm{a}$ & 0.35 & 0.017 & 0.35 & 0.017 \\
\hline Morgantown, WV & 2014 & 8,9 & $\mathrm{n} / \mathrm{a}$ & $\mathrm{n} / \mathrm{a}$ & $\mathrm{n} / \mathrm{a}$ & $\mathrm{n} / \mathrm{a}$ & $\mathrm{n} / \mathrm{a}$ & $\mathrm{n} / \mathrm{a}$ \\
\hline Morgantown, WV & 2014 & 9,10 & $\mathrm{n} / \mathrm{a}$ & $\mathrm{n} / \mathrm{a}$ & $\mathrm{n} / \mathrm{a}$ & $\mathrm{n} / \mathrm{a}$ & $\mathrm{n} / \mathrm{a}$ & $\mathrm{n} / \mathrm{a}$ \\
\hline Inwood, WV & 2013 & 1,2 & $\mathrm{n} / \mathrm{a}$ & $\mathrm{n} / \mathrm{a}$ & $\mathrm{n} / \mathrm{a}$ & $\mathrm{n} / \mathrm{a}$ & 0.47 & 0.007 \\
\hline Inwood, WV & 2013 & 2,3 & $\mathrm{n} / \mathrm{a}$ & $\mathrm{n} / \mathrm{a}$ & $\mathrm{n} / \mathrm{a}$ & $\mathrm{n} / \mathrm{a}$ & $\mathrm{n} / \mathrm{a}$ & $\mathrm{n} / \mathrm{a}$ \\
\hline Inwood, WV & 2013 & 3,4 & $\mathrm{n} / \mathrm{a}$ & $\mathrm{n} / \mathrm{a}$ & $\mathrm{n} / \mathrm{a}$ & $\mathrm{n} / \mathrm{a}$ & $\mathrm{n} / \mathrm{a}$ & $\mathrm{n} / \mathrm{a}$ \\
\hline Inwood, WV & 2013 & 4,5 & $\mathrm{n} / \mathrm{a}$ & $\mathrm{n} / \mathrm{a}$ & 0.70 & $<.0001$ & 0.72 & $<.0001$ \\
\hline Inwood, WV & 2013 & 5,6 & $\mathrm{n} / \mathrm{a}$ & $\mathrm{n} / \mathrm{a}$ & 0.68 & 0.003 & 0.68 & 0.003 \\
\hline Inwood, WV & 2013 & 6,7 & $\mathrm{n} / \mathrm{a}$ & $\mathrm{n} / \mathrm{a}$ & $\mathrm{n} / \mathrm{a}$ & $\mathrm{n} / \mathrm{a}$ & $\mathrm{n} / \mathrm{a}$ & $\mathrm{n} / \mathrm{a}$ \\
\hline Inwood, WV & 2013 & 7,8 & $\mathrm{n} / \mathrm{a}$ & $\mathrm{n} / \mathrm{a}$ & $\mathrm{n} / \mathrm{a}$ & $\mathrm{n} / \mathrm{a}$ & $\mathrm{n} / \mathrm{a}$ & $\mathrm{n} / \mathrm{a}$ \\
\hline Inwood, WV & 2013 & 8,9 & $\mathrm{n} / \mathrm{a}$ & $\mathrm{n} / \mathrm{a}$ & 0.99 & $<.0001$ & 0.99 & $<.0001$ \\
\hline Inwood, WV & 2014 & 1,2 & $\mathrm{n} / \mathrm{a}$ & $\mathrm{n} / \mathrm{a}$ & $\mathrm{n} / \mathrm{a}$ & $\mathrm{n} / \mathrm{a}$ & $\mathrm{n} / \mathrm{a}$ & $\mathrm{n} / \mathrm{a}$ \\
\hline Inwood, WV & 2014 & 2,3 & $\mathrm{n} / \mathrm{a}$ & $\mathrm{n} / \mathrm{a}$ & $\mathrm{n} / \mathrm{a}$ & $\mathrm{n} / \mathrm{a}$ & $\mathrm{n} / \mathrm{a}$ & $\mathrm{n} / \mathrm{a}$ \\
\hline Inwood, WV & 2014 & 3,4 & 0.17 & 0.070 & $\mathrm{n} / \mathrm{a}$ & $\mathrm{n} / \mathrm{a}$ & 0.46 & $<.0001$ \\
\hline Inwood, WV & 2014 & 4,5 & 0.45 & 0.000 & $\mathrm{n} / \mathrm{a}$ & $\mathrm{n} / \mathrm{a}$ & 0.48 & $<.0001$ \\
\hline Inwood, WV & 2014 & 5,6 & 0.42 & 0.061 & 0.50 & $<.0001$ & 0.44 & $<.0001$ \\
\hline Inwood, WV & 2014 & 6,7 & $\mathrm{n} / \mathrm{a}$ & $\mathrm{n} / \mathrm{a}$ & 0.49 & $<.0001$ & 0.44 & $<.0001$ \\
\hline Inwood, WV & 2014 & 7,8 & $\mathrm{n} / \mathrm{a}$ & $\mathrm{n} / \mathrm{a}$ & 0.77 & $<.0001$ & 0.64 & $<.0001$ \\
\hline Inwood, WV & 2014 & 8,9 & $\mathrm{n} / \mathrm{a}$ & $\mathrm{n} / \mathrm{a}$ & $\mathrm{n} / \mathrm{a}$ & $\mathrm{n} / \mathrm{a}$ & $\mathrm{n} / \mathrm{a}$ & $\mathrm{n} / \mathrm{a}$ \\
\hline Williamstown, NJ & 2013 & 1,2 & 0.63 & $<.0001$ & 0.42 & $\mathbf{0}$ & 0.00 & 0.221 \\
\hline Williamstown, NJ & 2013 & 2,3 & -0.15 & 0.799 & 0.33 & 0.004 & -0.07 & 0.723 \\
\hline Williamstown, NJ & 2013 & 3,4 & 0.50 & 0.000 & 0.66 & $<.0001$ & 0.50 & $<.0001$ \\
\hline Williamstown, NJ & 2013 & 4,5 & 0.37 & 0.004 & 0.46 & 0.005 & 0.51 & $<.0001$ \\
\hline Williamstown, NJ & 2013 & 5,6 & $\mathrm{n} / \mathrm{a}$ & $\mathrm{n} / \mathrm{a}$ & 0.65 & $<.0001$ & 0.70 & $<.0001$ \\
\hline Williamstown, NJ & 2013 & 6,7 & $\mathrm{n} / \mathrm{a}$ & $\mathrm{n} / \mathrm{a}$ & 0.08 & 0.340 & 0.08 & 0.340 \\
\hline Williamstown, NJ & 2014 & 1,2 & $\mathrm{n} / \mathrm{a}$ & $\mathrm{n} / \mathrm{a}$ & 0.86 & $<.0001$ & 0.48 & 0.004 \\
\hline Williamstown, NJ & 2014 & 2,3 & $\mathrm{n} / \mathrm{a}$ & $\mathrm{n} / \mathrm{a}$ & 0.41 & 0.001 & 0.34 & 0.043 \\
\hline Williamstown, NJ & 2014 & 3,4 & $\mathrm{n} / \mathrm{a}$ & $\mathrm{n} / \mathrm{a}$ & 0.05 & 0.335 & 0.60 & $<.0001$ \\
\hline Williamstown, NJ & 2014 & 4,5 & $\mathrm{n} / \mathrm{a}$ & $\mathrm{n} / \mathrm{a}$ & 0.34 & 0.008 & 0.22 & 0.022 \\
\hline Williamstown, NJ & 2014 & 5,6 & $\mathrm{n} / \mathrm{a}$ & $\mathrm{n} / \mathrm{a}$ & 0.22 & 0.077 & 0.30 & 0.010 \\
\hline Williamstown, NJ & 2014 & 6,7 & $\mathrm{n} / \mathrm{a}$ & $\mathrm{n} / \mathrm{a}$ & $\mathrm{n} / \mathrm{a}$ & $\mathrm{n} / \mathrm{a}$ & $\mathrm{n} / \mathrm{a}$ & $\mathrm{n} / \mathrm{a}$ \\
\hline Williamstown, NJ & 2014 & 7,8 & $\mathrm{n} / \mathrm{a}$ & $\mathrm{n} / \mathrm{a}$ & $\mathrm{n} / \mathrm{a}$ & $\mathrm{n} / \mathrm{a}$ & $\mathrm{n} / \mathrm{a}$ & $\mathrm{n} / \mathrm{a}$ \\
\hline
\end{tabular}

Index of association $(X)$ with its associated $P$ value $\left(P_{\mathrm{t}}\right)$ in parenthesis. For a two-tail test at $95 \%$ confidence level, $P_{\mathrm{t}}<0.025$ indicates significant positive association and $P_{\mathrm{t}}>0.975$ indicates significant negative association. Significant associations are in bold. $\mathrm{n} / \mathrm{a}$ listed when SADIE could not be conducted (0 individuals found). 
Table 7. Spatial association of total H. halys in early, mid, and late season

\begin{tabular}{ccccc}
\hline & & & Total & Total \\
Site & Year & Seasons & $X^{\mathrm{a}}$ & $\mathrm{P}$ \\
\hline Morgantown, WV & 2013 & Early - Mid & 0.09 & 0.221 \\
Morgantown, WV & 2013 & Mid - Late & 0.17 & 0.070 \\
Morgantown, WV & 2013 & Early - Late & 0.21 & 0.012 \\
Morgantown, WV & 2014 & Early - Mid & 0.20 & 0.091 \\
Morgantown, WV & 2014 & Mid - Late & $\mathbf{0 . 4 2}$ & $\mathbf{0 . 0 0 0}$ \\
Morgantown, WV & 2014 & Early - Late & $\mathbf{0 . 2 8}$ & $\mathbf{0 . 0 2 3}$ \\
Inwood, WV & 2013 & Early - Mid & 0.07 & 0.374 \\
Inwood, WV & 2013 & Mid - Late & -0.21 & 0.963 \\
Inwood, WV & 2013 & Early - Late & $\mathbf{0 . 5 6}$ & $<.0001$ \\
Inwood, WV & 2014 & Early - Mid & 0.15 & 0.107 \\
Inwood, WV & 2014 & Mid - Late & $\mathbf{0 . 6 1}$ & $<.0001$ \\
Inwood, WV & 2014 & Early - Late & 0.14 & 0.083 \\
Williamstown, NJ & 2013 & Early - Mid & 0.10 & 0.204 \\
Williamstown, NJ & 2013 & Mid - Late & -0.15 & 0.802 \\
Williamstown, NJ & 2013 & Early - Late & -0.28 & 0.987 \\
Williamstown, NJ & 2014 & Early - Mid & $\mathbf{0 . 4 3}$ & $\mathbf{0 . 0 0 2}$ \\
Williamstown, NJ & 2014 & Mid - Late & $\mathbf{0 . 3 2}$ & $\mathbf{0 . 0 1 8}$ \\
Williamstown, NJ & 2014 & Early - Late & $\mathbf{0 . 3 2}$ & $\mathbf{0 . 0 1 8}$ \\
\hline
\end{tabular}

${ }^{\text {a }}$ Index of association $(X)$ with its associated $P$ value $\left(P_{\mathrm{t}}\right)$ in parenthesis. For a two-tail test at 95\% confidence level, $P_{\mathrm{t}}<0.025$ indicates significant positive association and $P_{\mathrm{t}}>0.975$ indicates significant negative association. Significant associations are in bold. $\mathrm{n} / \mathrm{a}$ listed when SADIE could not be conducted ( 0 individuals found). 


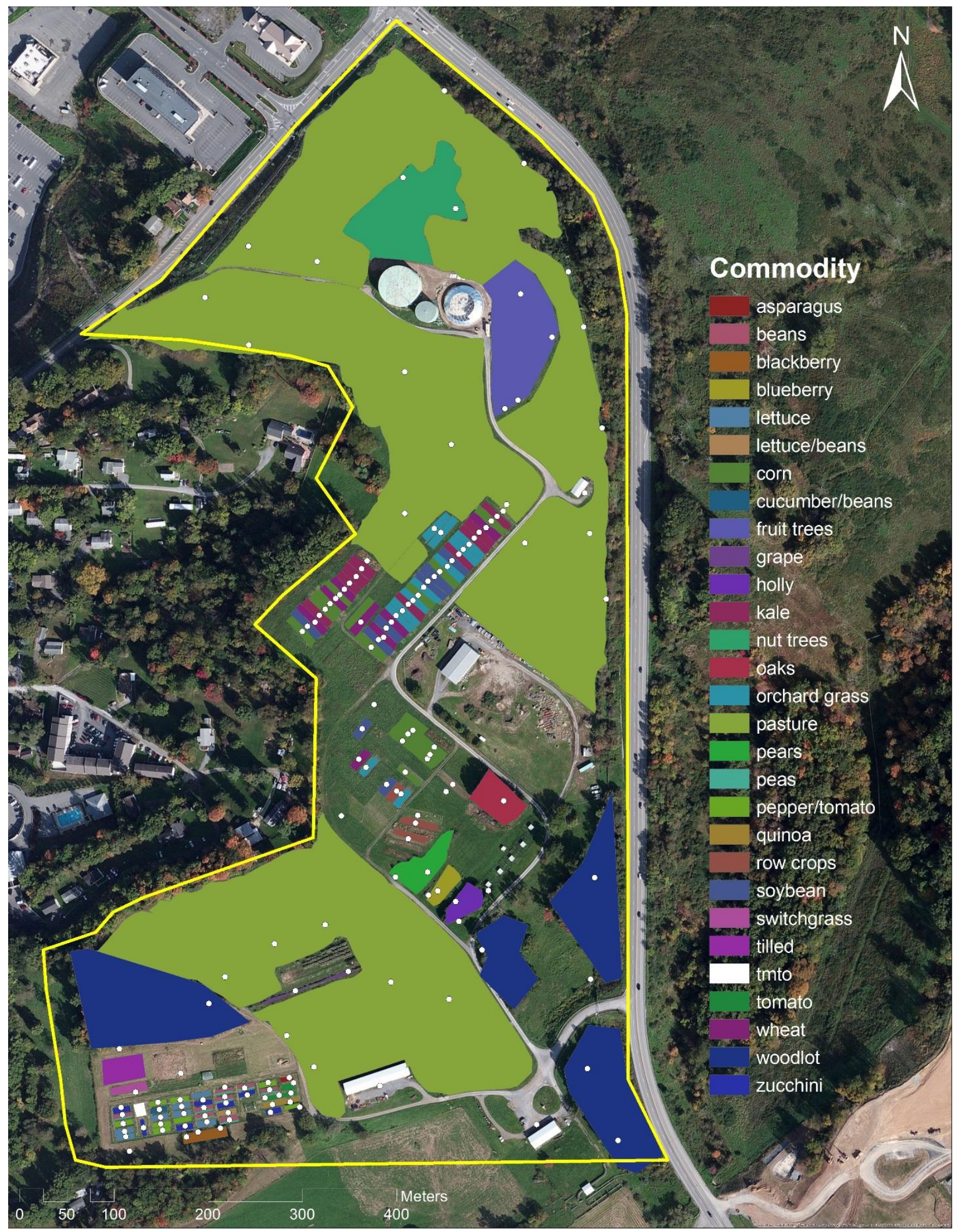

Fig. 1. Arrangement of sample locations throughout the West Virginia University organic farm (Morgantown, West Virginia) 


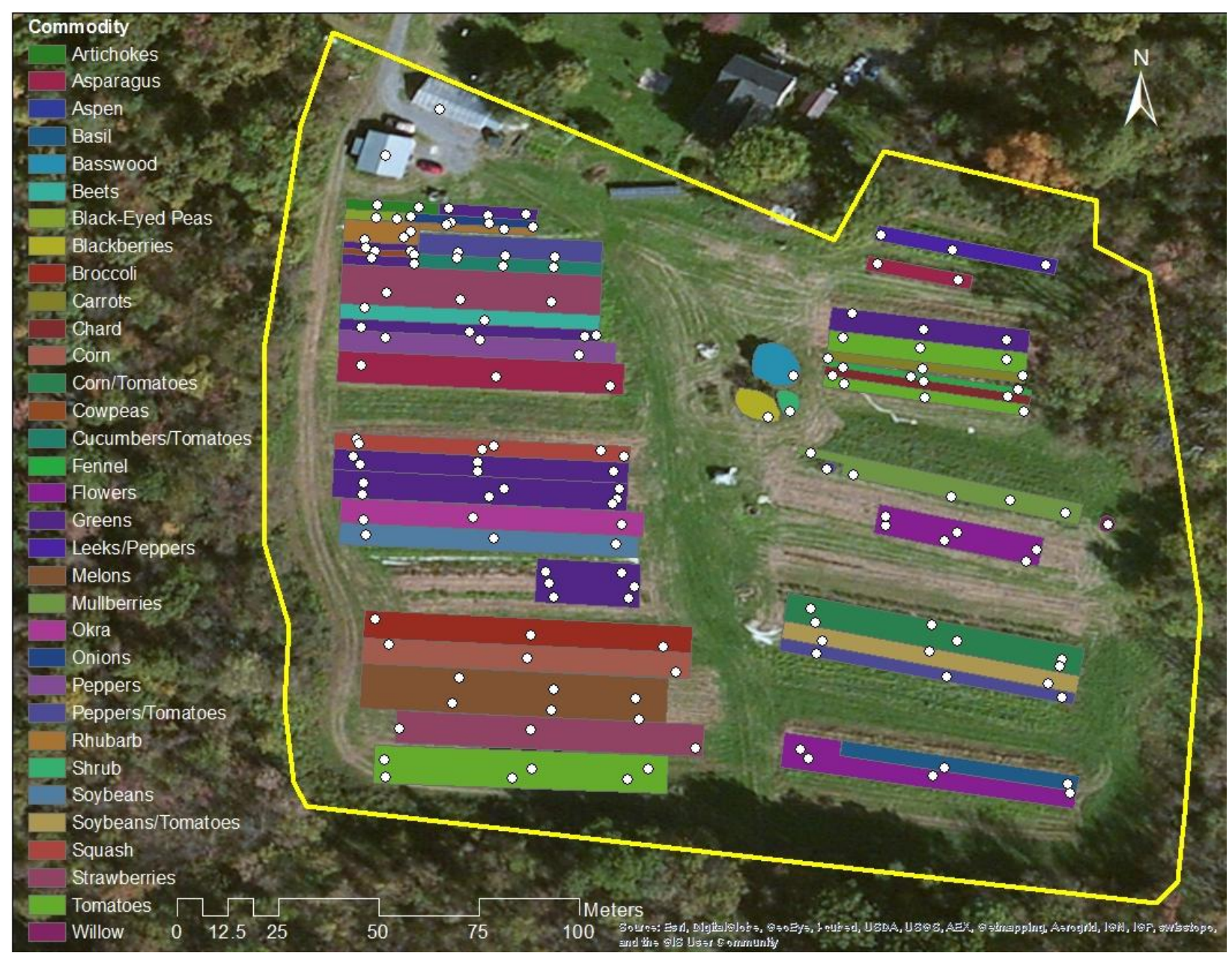

Fig. 2. Arrangement of sample locations throughout Redbud organic farm (Inwood, West Virginia) 


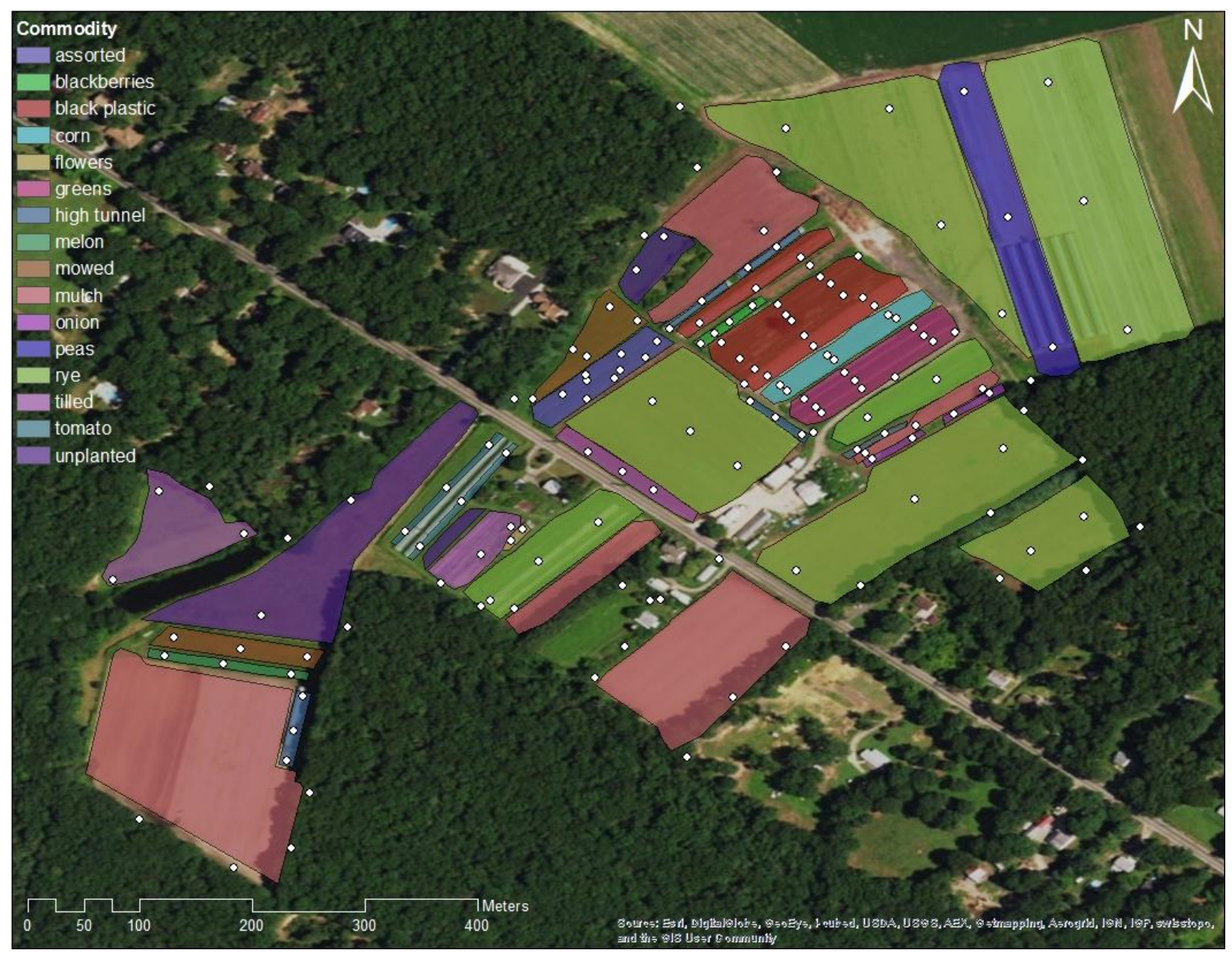

Fig. 3. Arrangement of sample locations throughout the Muth family organic farm (Williamstown, New Jersey) 


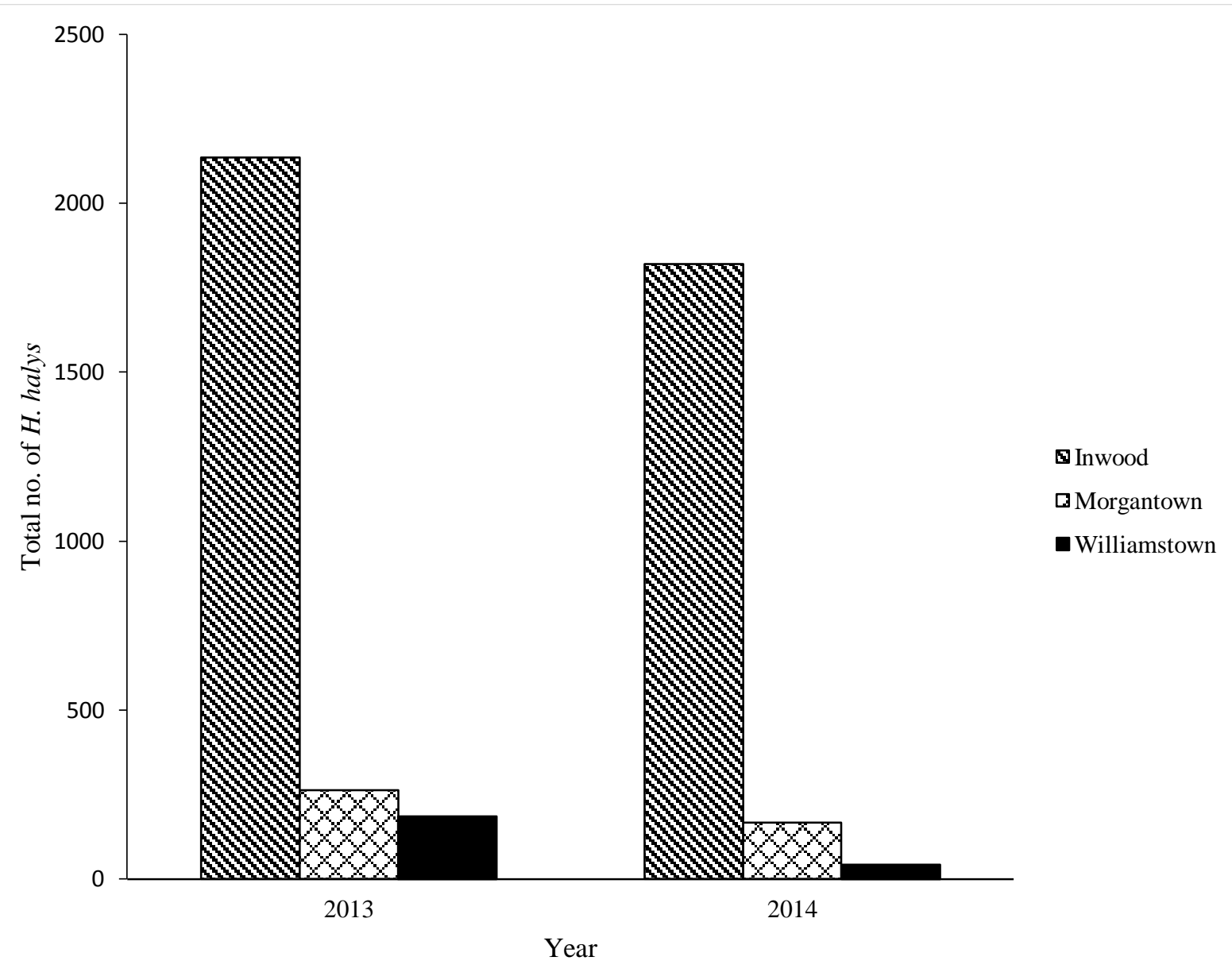

Fig. 4. Total number of $H$. halys observed per year at each site 
$\mathrm{a}$

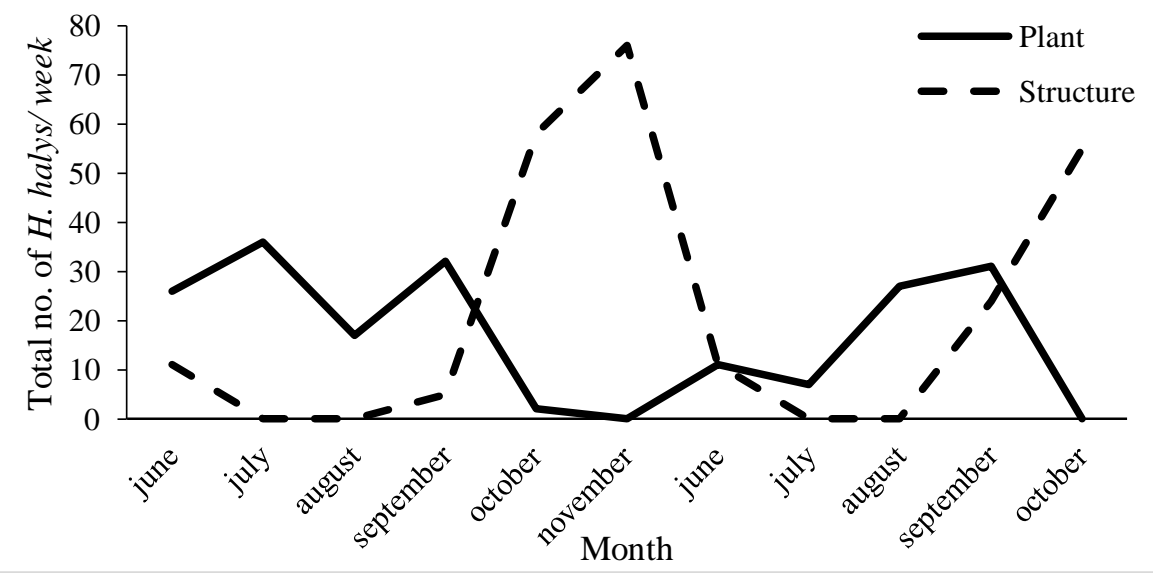

b
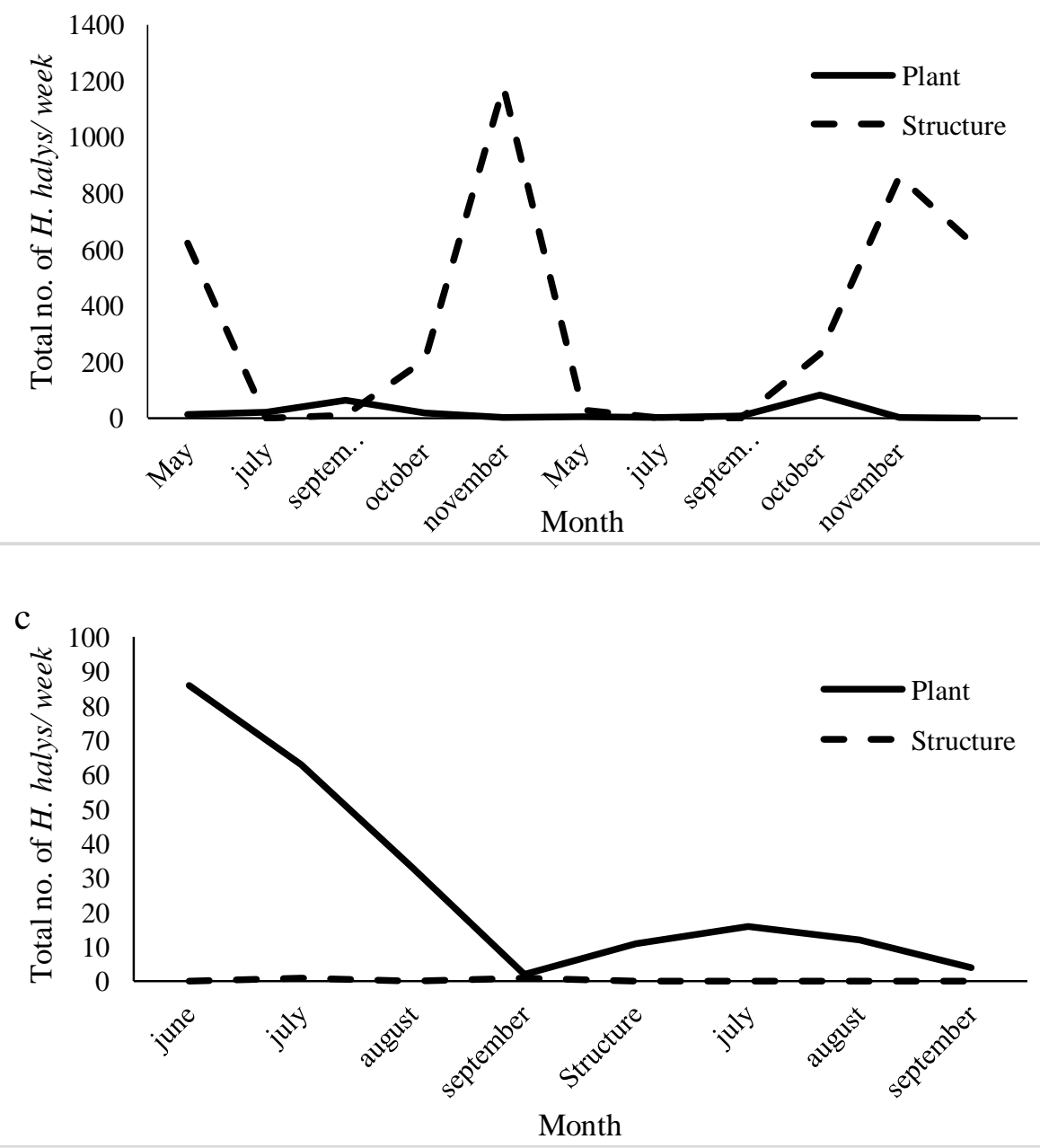

Fig. 5. Total number of $H$. halys on plants and structures per sample week in 2013-2014 in a) Morgantown, b) Inwood, and c) Williamstown 


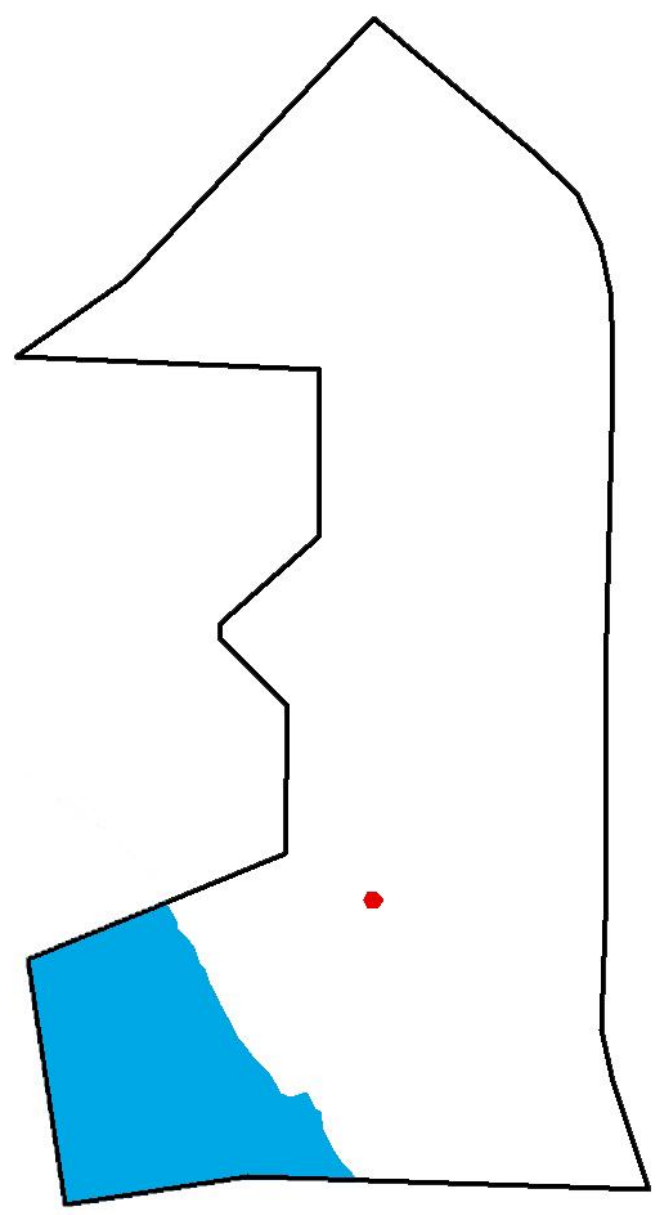

Fig. 6. Map of patches and gaps in observations of H. halys in 2013 in Morgantown, West Virginia. Red areas indicate patches with clusters of relatively large counts (i.e., $v_{i}>1.5$ ) and blue areas indicate gaps with clusters of relatively small counts (i.e., $v_{i}<-1.5$ ) 


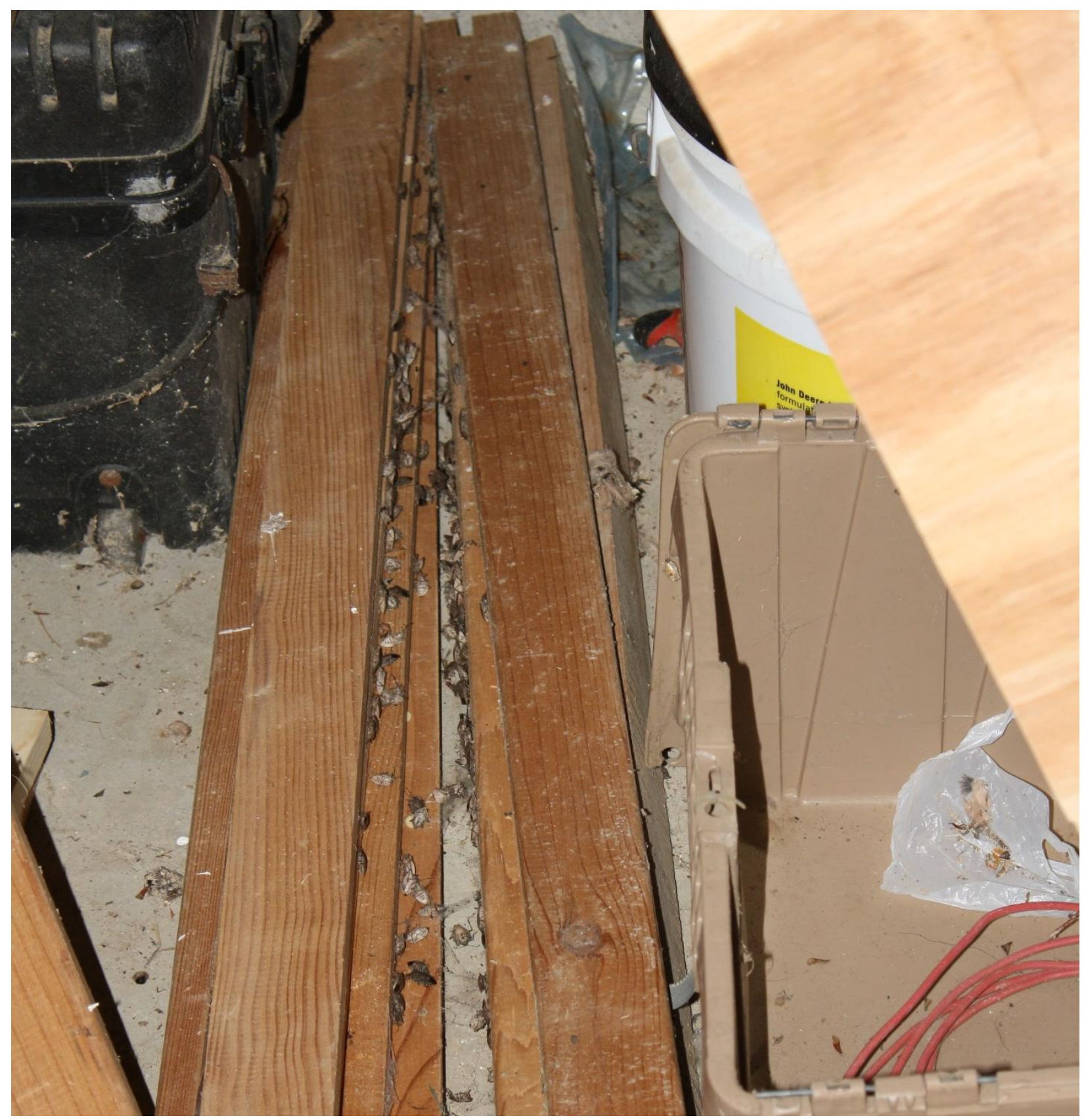

Fig. 7. Large numbers of $H$. halys adults overwintering in a shed 


\title{
Chapter 3: Movement of Halyomorpha halys (Hemiptera: Pentatomidae) to overwintering sites in an urban habitat
}

\begin{abstract}
Human-made structures serve as a key overwintering habitat for Halyomorpha halys (Hemiptera: Pentatomidae). Adults congregate on exterior surfaces of buildings in late September through November, before moving inside to aggregate in dry, cool, dark spaces, such as attics and garages. Under suitable conditions, they can form large aggregations in a single location, leading to nuisance problems for homeowners. This study is intended to increase understanding of $H$. halys overwintering behavior in hopes that it can be used to manage populations as they aggregate in the winter. A shopping center in Morgantown, West Virginia was surveyed for two years to determine when and where $H$. halys was present in greatest numbers, as well as whether or not it is associated with a preferred surface aspect (northwest, northeast, southeast, or southwest), or surface type (wall or entryway). There was a relationship between numbers of $H$. halys and surface aspect $(P<0.05)$, and significantly $(P<0.05)$ more insects were found on entryways. Count data were paired with geo-coordinates to perform spatial analysis by distance indices (SADIE) to characterize spatial distribution patterns and spatial associations of $H$. halys. Results indicate $H$. halys was randomly distributed over the site. No significant spatial patterns consisting of gaps with relatively low populations, or patches with relatively high populations were observed. Positive spatial associations between sample weeks across years suggests that these findings could be used to help create a pest management plan to control populations if patches are identified.
\end{abstract}

Keywords: Halyomorpha halys, SADIE, Spatial distribution, Spatial association 
Halyomorpha halys (Hemiptera: Pentatomidae) is a polyphytophagous insect first recorded in the Eastern U.S. in 1996 (Hoebeke and Carter 2003). Native to China, Korea, and Japan, H. halys was most likely introduced via shipping crates. Genetic markers have identified the source of the U.S. population as Beijing, in northeastern China (Xu et al. 2014). In the decade following its introduction, the $H$. halys population has grown, rapidly becoming an important agricultural and nuisance pest (Leskey et al. 2012). Feeding damage caused by $H$. halys causes unsightly blemishes and misshapen fruit, greatly reducing the market value (Nielsen and Hamilton 2009). Typical management involves the scheduled application of broad-spectrum insecticides (Leskey et al. 2012).

Human-made structures serve as a key overwintering habitat for $H$. halys (Hoebeke and Carter 2003). It was first detected in North America by homeowners that noticed adults appearing at their houses in the autumn. Adults congregate on exterior surfaces of buildings in late September through November, before moving inside (Hoebeke and Carter 2003). Once indoors, the adults aggregate in dry, cool, dark spaces, such as attics, and garages (Leskey et al. 2012). On warmer winter days they become active, creating nuisance problems (Hamilton et al. 2008, Inkley 2012). Under suitable conditions, they can form large aggregations in a single location. In years following the initial records, populations grew in number, increasing the frequency of nuisance problems (Hoebeke and Carter 2003). One account reports over 26,000 individuals recorded in a single home in early 2011 (Inkley 2012). Public demand for $H$. halys control methods has increased (Lee 2015). Bergmann and Raupp (2014) tested topical applications of several common, premixed pesticides, and found that carbaryl, permethrin, petroleum oil, acetamiprid, and insecticidal soap increased mortality of $H$. halys. Another study suggested that active compounds of essential oils eugenol, $l$-carvone, $p / l$-methone, pulegone, 
methyl salicylate, trans/cis-citral, methyl benzoate, and $\beta$-caryophyllene possessed repellent properties (Zhang et al. 2014).

There is also great potential for physical control of $H$. halys in overwintering habitat. Diapause makes $H$. halys easy to capture and dispose of, if a proper management schedule can be constructed, and overwintering box traps are already commonly used in Asia (Lee et al. 2013). However, since $H$. halys is highly mobile, homes and gardens are likely to be recolonized after treatment. Landscape-level management provides greater opportunity for effective control. By understanding which landscape features harbor large concentrations of $H$. halys, it is possible to perform effective landscape-level control. Several studies have reported details related to the overwintering habits of $H$. halys (Watanabe et al. 1994, Watanabe 1996, Lee et al. 2014, Inkley 2012, and Cambridge et al. 2015). In Japan, greater numbers of $H$. halys were observed at sunny overwintering sites than shaded sites (Watanabe et al. 1994). Individuals arrived at overwintering sites from 9:00 am - 4:00 pm, with the largest number of arrivals at 2:00 pm (Watanabe 1996). Lee et al. (2014) established that H. halys' natural overwintering habitat includes standing dead trees with thick bark, and that detector canines may be used to locate these sites. Inkley (2012) found that activity of overwintering $H$. halys correlated with daily high temperature. Cambridge et al. (2015) determined that larger numbers of $H$. halys overwintered near the upper floors of urban structures.

However, none of these studies analyzed spatial data about aggregation in urban environments, so it is not yet known which landscape features, if any, influence their distribution at overwintering sites. Additionally, previous studies did not consider various types land uses surrounding the site. The goal of this study was to characterize the spatial distribution of $H$. halys adults as they migrate towards an overwintering site, a mall in Morgantown, West Virginia 
and to investigate spatial relationships between the insect and the surrounding land uses. This study was intended to increase understanding of $H$. halys overwintering behavior to help managers control $H$. halys populations as they aggregate in the fall.

\section{Materials and Methods}

Study sites. This study was conducted at the Morgantown Mall, and the adjacent Lowe's Home Improvement store, located in Morgantown, WV (N39³7'36.43”, W7959'51.52"). These buildings measure $61,804.35 \mathrm{~m}^{2}$ and $16,255.64 \mathrm{~m}^{2}$, respectively. They are separated by $180 \mathrm{~m}$ of parking lot, and surrounded by a mixed environment of low, medium, and high intensity development, deciduous forest, cultivated crops, pasture, and herbaceous vegetation.

Sampling. Field sampling began in September in 2013, and October in 2014, when nighttime temperatures fell below $16^{\circ} \mathrm{C}$, and continued until the week of December $31^{\text {st }}$ each year. The perimeter of each building consisted of flat wall panels joining one another at corners of various angles. Each panel was visually surveyed at three different times each sample day: morning (8:00 am), noon (12:00 pm) and evening (4:00 pm). Samples included presence and number of $H$. halys, aspect of surface, and surface type (wall or entryway).

Characterization of spatial distribution. Global positioning system (GPS), GIS, and spatial analysis technologies were used to seek a pattern in $H$. halys presence on building surfaces. Samples included number of $H$. halys, surface type, and geo-coordinates. Coordinates of sample points corresponding with the center of the wall panel were recorded using a differentially-corrected global positioning system (DGPS, Mobile Mapper Pro, Magellan, Santa Clara, CA). Counts were paired with geo-coordinates and were spatially analyzed using spatial analysis by distance indices (SADIE) (Perry 1995). SADIE characterizes spatial patterns by 
quantifying the degree of clustering within the study area using the aggregation index $I_{a}$, expressed as $I_{a}=D / E_{a} . D$ is the distance to regularity, the minimum distance samples in a study area must move to achieve a uniform distribution. $E_{a}$ is the expected mean distance to regularity. A uniform spatial pattern is represented by $I_{a}<1$, while $I_{a}>1$ represents a spatially aggregated pattern. $I_{a}=1$ indicates a spatially random pattern (Perry et al. 1999). SADIE was used to test the null hypothesis that $H$. halys are distributed randomly among the sample points. All SADIE statistics were calculated using SADIEShell version 2.0 (Rothamsted Experimental Station, Harpenden, Herts, UK).

Spatial association analysis. SADIE was also used to measure spatial associations between sample years by comparing cluster indices for each dataset. Positive spatial associations represent patches or gaps that occur in the same location on different sample dates. Patches alternating with gaps on different sample dates represent negative spatial associations. Spatial association is quantified by SADIE index $X$, the correlation coefficient between clustering indices of each dataset. When $X>0$, there is a positive spatial association. When $X<0$, there is a negative association. Random gaps or patches were represented by $X \approx 0$. We tested the null hypothesis that each dataset was random with respect to the others.

Statistical analysis. Conventional statistics including t-tests and analyses of variance (ANOVA) were used to analyze non-spatial associations between number of $H$. halys, and surface aspect and type. These tests were completed using SigmaPlot (Systat Software Inc., San Jose, CA). After failing the Shapiro-Wilk test for normality $(P<0.05)$, Mann-Whitney rank sum tests were used to determine relationships between surface types (wall and entryway) in both years. A Brown-Forsythe equal variance test was used to determine the relationship between the numbers of $H$. halys per surface type between years. Kruskal-Wallis one way analysis of 
variance on ranks was used to examine the relationship between number of $H$. halys per surface aspect, and the year. A Brown-Forsythe equal variance test was also used to determine the relationship between the numbers of $H$. halys per surface aspect between years.

\section{Results}

The highest numbers of $H$. halys were recorded on October 18 in 2013, and October 1 2014 (Fig. 1). A second, smaller peak occurred on November 12 in 2013, and November 11 in 2014. During each year, $H$. halys was most abundant on northwest-facing surfaces, and least abundant on southwest-facing surfaces (Fig. 2). A Kruskal-Wallis one way analysis of variance on ranks revealed a significant difference between the numbers found at each of the four aspects $(H=9.876$; d.f. $=3 ; P=0.020)($ Table 1$)$. Results of the Brown-Forsythe equal variance test showed that there were no significant interactions between aspect and the year $(F=0.579$; d.f. $=$ $1,3 ; P=0.633)($ Table 2$)$.

In both years greater raw abundances of $H$. halys occurred on entryways (Fig. 3). MannWhitney rank sum test results indicated that in 2013 there was no significant difference between the numbers of $H$. halys on walls and entryways $(T=161.5$; d.f. $=11 ; P=0.524)$. However, in 2014 significantly more $H$. halys were found on entryways than on walls $(T=197.5$; d.f. $=11 ; P$ $=0.007)$. When years were combined, results of the Mann-Whitney rank sum test indicate a significantly more were found on entryways $(T=718.5$; d.f. $=23 ; P=0.007)$. Brown-Forsythe equal variance test showed no significant interaction between surface type and year $(F=0.759$; d.f. $=1,1 ; P=0.388)($ Table 3$)$.

Morning counts of $H$. halys had $I_{\mathrm{a}}>1$ in late October, mid-November, and early December in 2013, and late October, all of November, and early December in 2014 (Table 4), 
indicating varying levels of spatial aggregation. However, significant aggregations $(P \leq 0.05)$

were not recorded. In 2013, only the aggregations in mid-November had significant $(P<0.025)$ positive spatial associations (Table 5). In 2014, the aggregations in late October, November, and early December have positive spatial associations. Between years, the aggregations in the third and fourth weeks of November are positively associated (Table 6).

Noon counts of $H$. halys had $I_{\mathrm{a}}>1$ in late September, late October, and early December in 2013, and mid-October through early November, and early December in 2014 (Table 7). These aggregations were also not significant. Positive spatial associations of noon counts were not always associated with aggregations (Table 5). In such cases, areas of relatively low counts (gaps) were found in the same locations between sample dates. In 2013, these associations between aggregations did not occur. Positive associations in 2014 occurred between the second and third weeks of October, the last week of October and the first week of November, and the first and second weeks of December. Between years, positive associations between aggregations occurred in the third and fourth weeks of October (Table 6). A significantly negative association $(P>0.975)$ occurs between the first weeks of November.

Evening counts of $H$. halys had $I_{\mathrm{a}}>1$ in early November in 2013, late-October through mid-November, and early through mid-December in 2014 (Table 8). However, these aggregations were also not significant. Positive spatial associations of evening counts were not always associated with aggregations (Table 5). In 2013, these associations between aggregations did not occur. In 2014, positive spatial associations occurred between the last week of October and the first week of November, and the first and second weeks of December. Between years, positive spatial associations between aggregations occurred in the first weeks of November (Table 6). 
Pooling $H$. halys counts for each day, $I_{\mathrm{a}}>1$ was observed in late September, mid and late October, mid-November, and mid-December in 2013, and late October, early and late November, and early December in 2014 (Table 9). Again, none of these aggregations were significant. Positive spatial associations of total counts were not always associated with aggregations (Table 5). In 2013, these associations between aggregations did not occur. In 2014, positive spatial associations occurred between the last week of October and the first week of November, the third and fourth weeks of November, the fourth week of November and the first week of December, and the first and second weeks of December. Between years, positive spatial associations between aggregations occurred in the first weeks of October, and the third weeks of November (Table 6). A significant negative association was found between aggregations in the second weeks of December.

SADIE maps were made by pooling $H$. halys counts for mornings, noons, and evenings each year, depicting the locations of spatial aggregations (Figs. 4 and 5). Gaps generally occurred on southwest-facing surfaces. Patches occurred on northeast and southeast-facing surfaces.

\section{Discussion}

This study recorded similar numbers of $H$. halys in 2013 and 2014 (Fig. 1). In both years, numbers of $H$. halys peaked in October, and again in November. This second peak could be attributed to a second generation reaching adulthood and achieving flight capability late in the season, or possibly individuals hitchhiking with the increased car traffic during the holiday shopping season. There were significantly more insects found on northwest-facing surfaces (Fig.

2). Additionally, significantly more $H$. halys were found on entryways than on walls (Fig. 3).

No significant patches or gaps of $H$. halys distributions were recorded in either year. However, 
positive spatial associations between years were detected in $H$. halys distributions occurring during the fourth week of October, and the third week of November (Table 6). Additionally, a negative spatial association was detected between $H$. halys distributions occurring during the second week of December.

The $I_{\mathrm{a}}$ values found over the course of this study describe a population of insects with a random distribution across the landscape (Tables $4,7,8$, and 9). This can be partially attributed to $H$. halys' wide range of host plants, and its high capacity for dispersal, as it is capable of living in a variety of microhabitats, and traveling considerable distances to overwintering sites (Leskey and Hamilton 2015, Lee and Leskey 2014). Although none of the $I_{\mathrm{a}}$ values indicating a level of aggregation were statistically significant, they still offer some insight on which parts of the building harbor relatively high and low densities of $H$. halys (Figs. 4 and 5). Most patches occurred during the noon sample period, suggesting that midday is the best time to treat with chemical or mechanical control. Additionally, gaps occurred in similar locations in morning and evening. This suggests that $H$. halys travels the most during the day, and stays in the same location at night.

Analysis of the association index $X$ reveals that there is a level of predictability to populations of $H$. halys on the surfaces of the buildings. In 2014, positive spatial associations occurred between the last week of October and the first week of November, the third and fourth weeks of November, the fourth week of November and the first week of December, and the first and second weeks of December (Table 5). This suggests that during these time periods, $H$. halys' spatial distribution remains relatively unchanged. Between years, positive spatial associations between aggregations occurred in the first weeks of October, and the third weeks of 
November (Table 6). During these times, H. halys distributions had the same spatial pattern each year.

Funayama (2015) found that there was no significant association between number of $H$. halys trapped, and cardinal direction of trap placement, noting that proportion of individuals captured at each direction changed from year to year. The results of this study conflict with these findings, as more were found on the northwest surfaces (Fig 2). While the Funayama experiment was conducted in a rural setting at a building surrounded by forest as close as $30 \mathrm{~m}$, our study took place in a developed area, where natural cover is $40 \mathrm{~m}$ at its nearest, and over 200 $\mathrm{m}$ at its farthest. Utilizing the observation that $H$. halys numbers were more highly concentrated on entryways, (Fig 3) we can predict that these locations will harbor greater numbers as individuals move towards overwintering sites. Combining these findings with spatial analysis suggests that the most effective plan for managing $H$. halys as it moves into human-made overwintering sites is to focus on northwest-facing entryways during the first weeks of October, and again in the middle of November. By doing this, the largest number of insects can be affected by management efforts.

\section{Literature Cited}

Bergmann, E.J., and M. J. Raupp. 2014. Efficacies of common ready-to-use insecticides against Halyomorpha halys (Hemiptera: Pentatomidae). Fla. Entomol 97: 791-800.

Cambridge, J., A. Payenski, and G. C. Hamilton. 2015. The distribution of overwintering brown marmorated stink bugs (Hemiptera: Pentatomidae) in college dormitories. Fla. Entomol. 98: $1257-1259$. 
Funayama, K. 2015. Relationship between the cardinal direction of passive trap placement and the number of captured adults at hibernation sites of Halyomorpha halys (Hemiptera: Pentatomidae). Appl. Entomol. Zool. 50: 487-490.

Hamilton, G. C., P. W. Shearer, and A. L. Nielsen. 2008. Brown marmorated stink bug. A nonnative insect in New Jersey. Fact sheetFS002. Rutgers, the State University of NJ. https://njaes.rutgers.edu/pubs/publication.asp?pid=fs002. Accessed 2016 March 10.

Hoebeke E., and E. C. Carter. 2003. Halyomorpha halys (Stål) (Heteroptera: Pentatomidae): a polyphagous plant pest from Asia newly detected in North America. Proc. Entomol. Soc. Wash. 105: 225-237.

Inkley, D. B. 2012. Characteristics of home invasion by the brown marmorated stink bug (Hemiptera: Pentatomidae). J. Entomol. Sci. 47: 125-130.

Lee, D. H. 2015. Current status of research progress on the biology and management of Halyomorpha halys (Hemiptera: Pentatomidae) as an invasive species. Appl. Entomol Zool. 50: $277-290$.

Lee, D. H., B. D. Short, S. V. Joseph, J. C. Bergh, and T. C. Leskey. 2013. Review of the biology, ecology, and management of Halyomorpha halys (Hemiptera: Pentatomidae) in China, Japan, and the Republic of Korea. Environ. Entomol. 42: 627-641.

Lee, D. H., A. L. Nielsen, and T. C. Leskey. 2014. Dispersal capacity and behavior of nymphal stages of Halyomorpha halys (Hemiptera: Pentatomidae) evaluated under laboratory and field conditions. J. Insect Behav. 27: 639-651. 
Lee, D. H., and T. C. Leskey. 2015. Flight behavior of foragin and overwintering brown marmorated stink bug, Halyomorpha halys (Hemiptera: Pentatomidae). Bul. Entomol. Res. 105: 566-573.

Leskey, T. C., and C. G. Hamilton. 2015. Brown marmorated stink bug working group meeting. http://www.stopbmsb.org/stopBMSB/assets/File/Research/BMSB-IWG-Jun-2015/BMSBWorking-Group-Meeting-Report-Jun-2015.pdf. Accessed 2014, June 10.

Leskey, T. C., C. G. Hamilton, A. L. Nielsen, D. F. Polk, C. Rodriguez-Saona., J. C. Bergh, and S. E. Wright. 2012. Pest status of the brown marmorated stink bug, Halyomorpha halys in the USA. Outl. Pest Manag. 23: 218-226.

Nielsen A. L., and G. C. Hamilton. 2009. Seasonal occurrence and impact of Halyomorpha halys (Hemiptera: Pentatomidae) in tree fruit. J. Econ. Entomol. 102: 1133-1140.

Perry, J. N., 1995. Spatial analysis by distance indices. J. Anim. Ecol. 64: 303-314.

Perry, J. N., L. Winder, J. M. Holland, and R. D. Alston. 1999. Red-blue dots for detecting clusters in count data. Ecol. Lett. 2: 106-113.

Watanabe, M. 1996. How to stop stink bugs from invading our homes. Insectarium 33: 42-45. Watanabe, M., R. Arakawa, Y. Shinagawa, and T. Okazawa. 1994. Overwintering flight of brown-marmorated stink bug, Halyomorpha mista to the buildings. Anim. Health 45: 2531.

Xu, J., D. M. Fonseca, G. C. Hamilton, K. A. Hoelmer, and A.L. Nielsen. 2014. Tracing the origin of US brown marmorated stink bugs, Halyomorpha halys. Biol. Invas. 16: 153-166. 
Zhang, Q. H., R. G. Schneidmiller, D. R. Hoover, G. Zhou, A. Margaryan, and P. Bryant. 2014. Essential oils as spatial repellents for the brown marmorated stink bug Halyomorpha halys (Stål) (Hemiptera: Pentatomidae). J. Appl. Entomol. 138: 490-499. 
Table 1. Results of one-way ANOVA for the number $H$. halys per surface aspect (northwest, northeast, southeast, and southwest)

\begin{tabular}{cccccc}
\hline \hline Group & $\mathrm{N}$ & Missing & Median & $25 \%$ & $75 \%$ \\
\hline Northeast & 25 & 1 & 0.125 & 0.0469 & 0.406 \\
Northwest & 25 & 1 & 0.302 & 0.151 & 0.63 \\
Southeast & 25 & 1 & 0.219 & 0.0885 & 0.365 \\
Southwest & 25 & 1 & 0.0926 & 0.0231 & 0.162 \\
\hline
\end{tabular}


Table 2. Results of ANOVA for the number $H$. halys per year with four different surface aspects (northwest, northeast, southeast, and southwest)

\begin{tabular}{cccccc}
\hline \hline Source of Variation & DF & SS & MS & F & P \\
\hline Year & 1 & 0.246 & 0.246 & 0.507 & 0.478 \\
Aspect & 3 & 3.114 & 1.038 & 2.141 & 0.101 \\
Year x Aspect & 3 & 0.835 & 0.278 & 0.574 & 0.633 \\
Residual & 88 & 42.654 & 0.485 & & \\
Total & 95 & 46.848 & 0.493 & & \\
\hline
\end{tabular}


Table 3. Results of ANOVA for the number H. halys per year with two different surface types (walls, and entryways)

\begin{tabular}{llllll}
\hline $\begin{array}{l}\text { Source of } \\
\text { Variation }\end{array}$ & DF & SS & MS & F & P \\
\hline Walls & 1 & 0.113 & 0.113 & 0.257 & 0.615 \\
Entryways & 1 & 1.726 & 1.726 & 3.91 & 0.054 \\
Doors x & 1 & 0.335 & 0.335 & 0.759 & 0.388 \\
Entryways & 44 & 19.418 & 0.441 & & \\
Residual & 47 & 21.592 & 0.459 & & \\
Total & & &
\end{tabular}


Table 4. SADIE statistics for the spatial distribution of $H$. halys found in the morning

\begin{tabular}{ccccc}
\hline \hline Date & Average \# & SD & $I_{\mathrm{a}}{ }^{\mathrm{a}}$ & $P_{a}$ \\
\hline $9 / 30 / 2013$ & 0.21 & 0.485 & 0.94 & 0.499 \\
$10 / 10 / 2013$ & 0.61 & 1.144 & 0.81 & 0.672 \\
$10 / 18 / 2013$ & 1.39 & 1.413 & 1.07 & 0.333 \\
$10 / 29 / 2013$ & 0.55 & 0.833 & 0.72 & 0.832 \\
$11 / 5 / 2013$ & 0.39 & 0.747 & 0.65 & 0.916 \\
$11 / 12 / 2013$ & 0.09 & 0.663 & 1.28 & 0.183 \\
$11 / 19 / 2013$ & 0.24 & 0.650 & 1.05 & 0.350 \\
$11 / 26 / 2013$ & 0.21 & 1.571 & 0.88 & 0.595 \\
$12 / 3 / 2013$ & 0.30 & 0.292 & 1.13 & 0.318 \\
$12 / 10 / 2013$ & 0.09 & 0.174 & 0.92 & 0.572 \\
$12 / 18 / 2013$ & 0.03 & 5.174 & $\mathrm{n} / \mathrm{a}$ & $\mathrm{n} / \mathrm{a}$ \\
$12 / 26 / 2013$ & 0.03 & 1.415 & 0.97 & 0.452 \\
$10 / 1 / 2014$ & 3.33 & 1.555 & 0.74 & 0.787 \\
$10 / 16 / 2014$ & 0.76 & 0.816 & 1.17 & 0.239 \\
$10 / 20 / 2014$ & 0.67 & 0.867 & 1.07 & 0.340 \\
$10 / 30 / 2014$ & 0.33 & 1.001 & 1.24 & 0.172 \\
$11 / 4 / 2014$ & 0.24 & 0.883 & 1.00 & 0.412 \\
$11 / 11 / 2014$ & 0.58 & 0.650 & 1.33 & 0.138 \\
$11 / 22 / 2014$ & 0.30 & 0.761 & 1.22 & 0.197 \\
$11 / 25 / 2014$ & 0.21 & 1.435 & 1.04 & 0.351 \\
$12 / 4 / 2014$ & 0.27 & 0.728 & 0.92 & 0.572 \\
$12 / 12 / 2014$ & 0.39 & $\mathrm{n} / \mathrm{a}$ & 1.07 & 0.348 \\
$12 / 19 / 2014$ & 0.30 & $\mathrm{n} / \mathrm{a}$ & $\mathrm{n} / \mathrm{a}$ \\
$12 / 26 / 2014$ & 0.00 & $\mathrm{a}$ & & \\
\hline
\end{tabular}

${ }^{a}$ Overall degree of clustering $\left(I_{\mathrm{a}}\right)$ with its associated $P$ value $\left(P_{\mathrm{a}}\right)$ in parenthesis. $I_{\mathrm{a}}=1$ suggests a random, $I_{\mathrm{a}}>1$ suggests an aggregated, and $I_{\mathrm{a}}<1$ suggests a regular spatial pattern. Significant $(P<0.05)$ associations are in bold. $\mathrm{n} / \mathrm{a}$ listed when SADIE could not be conducted ( 0 individuals found). 
Table 5. Spatial association of $H$. halys found in the morning, noon, and evening within years

\begin{tabular}{|c|c|c|c|c|c|c|c|c|c|}
\hline \multirow[b]{2}{*}{ Year } & \multirow[b]{2}{*}{ Dates } & \multicolumn{2}{|c|}{ Morning } & \multicolumn{2}{|c|}{ Noon } & \multicolumn{2}{|c|}{ Evening } & \multicolumn{2}{|c|}{ Total } \\
\hline & & $X^{\mathrm{a}}$ & $P_{t}$ & $X$ & $P_{t}$ & $X$ & $P_{t}$ & $X$ & $P_{t}$ \\
\hline \multirow[t]{11}{*}{2013} & $9 / 30-10 / 10$ & 0.62 & 0.000 & 0.81 & 0.001 & 0.22 & 0.154 & 0.58 & 0.000 \\
\hline & $10 / 10-10 / 18$ & 0.12 & 0.277 & 0.77 & 0.024 & 0.64 & 0.001 & 0.27 & 0.074 \\
\hline & $10 / 18-10 / 29$ & 0.04 & 0.597 & 0.03 & 0.192 & 0.28 & 0.077 & 0.18 & 0.164 \\
\hline & $10 / 29-11 / 5$ & 0.05 & 0.393 & 0.09 & 0.667 & 0.63 & 0.004 & 0.08 & 0.336 \\
\hline & $11 / 5-11 / 12$ & 0.04 & 0.569 & 0.78 & 0.003 & 0.19 & 0.187 & 0.53 & 0.002 \\
\hline & $11 / 12-11 / 19$ & 0.61 & 0.000 & 0.43 & 0.037 & 0.16 & 0.390 & 0.47 & 0.003 \\
\hline & $11 / 19-11 / 26$ & 0.33 & 0.028 & 0.76 & 0.000 & 0.34 & 0.061 & 0.58 & 0.000 \\
\hline & $11 / 26-12 / 3$ & 0.19 & 0.847 & 0.53 & 0.006 & $\mathrm{n} / \mathrm{a}$ & $\mathrm{n} / \mathrm{a}$ & 0.20 & 0.128 \\
\hline & $12 / 3-12 / 10$ & 0.06 & 0.357 & 0.19 & 0.186 & $\mathrm{n} / \mathrm{a}$ & $\mathrm{n} / \mathrm{a}$ & -0.10 & 0.703 \\
\hline & $12 / 10-12 / 18$ & $\mathrm{n} / \mathrm{a}$ & $\mathrm{n} / \mathrm{a}$ & 0.20 & 0.249 & 0.94 & 0.002 & 0.62 & 0.000 \\
\hline & $12 / 18-12 / 26$ & $\mathrm{n} / \mathrm{a}$ & $\mathrm{n} / \mathrm{a}$ & $\mathrm{n} / \mathrm{a}$ & $\mathrm{n} / \mathrm{a}$ & 0.42 & 0.060 & 0.73 & 0.000 \\
\hline \multirow[t]{11}{*}{2014} & $10 / 1-10 / 16$ & 0.65 & 0.002 & 0.80 & 0.009 & 0.26 & 0.089 & 0.53 & 0.008 \\
\hline & $10 / 16-10 / 20$ & 0.37 & 0.044 & 0.95 & 0.001 & 0.54 & 0.004 & 0.61 & 0.003 \\
\hline & $10 / 20-10 / 30$ & 0.45 & 0.009 & 0.51 & 0.041 & 0.35 & 0.050 & 0.40 & 0.040 \\
\hline & $10 / 30-11 / 4$ & 0.59 & 0.000 & 0.48 & 0.023 & 0.72 & 0.003 & 0.38 & 0.016 \\
\hline & $11 / 4-11 / 11$ & 0.38 & 0.040 & 0.35 & 0.057 & 0.31 & 0.063 & -0.01 & 0.498 \\
\hline & $11 / 11-11 / 22$ & 0.65 & 0.007 & 0.33 & 0.063 & 0.42 & 0.032 & 0.69 & 0.002 \\
\hline & $11 / 22-11 / 25$ & 0.68 & $<.0001$ & 0.66 & 0.013 & 0.82 & 0.004 & 0.62 & 0.001 \\
\hline & $11 / 25-12 / 4$ & 0.74 & $<.0001$ & 0.75 & 0.007 & 0.80 & 0.004 & 0.49 & 0.004 \\
\hline & $12 / 4-12 / 12$ & 0.10 & 0.693 & 0.78 & 0.004 & 0.81 & 0.005 & 0.73 & $<.0001$ \\
\hline & $12 / 12-12 / 19$ & 0.11 & 0.724 & 0.58 & 0.013 & 0.24 & 0.102 & 0.52 & 0.003 \\
\hline & $12 / 19-12 / 26$ & $\mathrm{n} / \mathrm{a}$ & $\mathrm{n} / \mathrm{a}$ & $\mathrm{n} / \mathrm{a}$ & $\mathrm{n} / \mathrm{a}$ & $\mathrm{n} / \mathrm{a}$ & $\mathrm{n} / \mathrm{a}$ & $\mathrm{n} / \mathrm{a}$ & $\mathrm{n} / \mathrm{a}$ \\
\hline
\end{tabular}

${ }^{\text {a }}$ Index of association $(X)$ with its associated $P$ value $\left(P_{\mathrm{t}}\right)$ in parenthesis. For a two-tail test at $95 \%$ confidence level, $P_{\mathrm{t}}<0.025$ indicates significant positive association and $P_{\mathrm{t}}>0.975$ indicates significant negative association.

Significant associations are in bold. n/a listed when SADIE could not be conducted ( 0 individuals found). 
Table 6. Spatial association of $H$. halys found in the morning, noon, and evening between years

\begin{tabular}{|c|c|c|c|c|c|c|c|c|}
\hline \multirow[b]{2}{*}{ Dates } & \multicolumn{2}{|c|}{ Morning } & \multicolumn{2}{|c|}{ Noon } & \multicolumn{2}{|c|}{ Evening } & \multicolumn{2}{|c|}{ Total } \\
\hline & $X^{\mathrm{a}}$ & $P_{t}$ & $\mathrm{X}$ & $P_{t}$ & $X$ & $P_{t}$ & $X$ & $P_{t}$ \\
\hline $\begin{array}{c}9 / 30- \\
10 / 1\end{array}$ & -0.11 & 0.706 & -0.21 & 0.838 & 0.26 & 0.068 & -0.31 & 0.954 \\
\hline $\begin{array}{c}10 / 10- \\
10 / 16\end{array}$ & -0.20 & 0.862 & -0.03 & 0.550 & 0.22 & 0.134 & -0.10 & 0.718 \\
\hline $\begin{array}{c}10 / 18- \\
10 / 20\end{array}$ & 0.30 & 0.041 & 0.71 & 0.000 & -0.01 & 0.519 & 0.20 & 0.127 \\
\hline $\begin{array}{c}10 / 29- \\
10 / 30\end{array}$ & 0.10 & 0.291 & 0.37 & 0.016 & 0.00 & 0.488 & 0.38 & 0.013 \\
\hline $\begin{array}{c}11 / 5- \\
11 / 4\end{array}$ & 0.20 & 0.163 & -0.42 & 0.994 & 0.44 & 0.005 & 0.04 & 0.420 \\
\hline $\begin{array}{c}11 / 12- \\
11 / 11\end{array}$ & 0.15 & 0.243 & 0.14 & 0.220 & 0.28 & 0.067 & -0.04 & 0.573 \\
\hline $\begin{array}{c}11 / 19- \\
11 / 22\end{array}$ & 0.53 & 0.001 & 0.43 & 0.010 & $\mathrm{n} / \mathrm{a}$ & $\mathrm{n} / \mathrm{a}$ & 0.45 & 0.010 \\
\hline $\begin{array}{c}11 / 26- \\
11 / 25\end{array}$ & 0.39 & 0.014 & 0.21 & 0.123 & 0.13 & 0.266 & 0.17 & 0.163 \\
\hline $\begin{array}{c}12 / 3- \\
12 / 4\end{array}$ & -0.06 & 0.614 & 0.22 & 0.116 & na & na & 0.39 & 0.015 \\
\hline $\begin{array}{c}12 / 10- \\
12 / 12\end{array}$ & $\mathrm{n} / \mathrm{a}$ & $\mathrm{n} / \mathrm{a}$ & -0.35 & 0.975 & -0.22 & 0.859 & -0.37 & 0.986 \\
\hline $\begin{array}{c}12 / 18- \\
12 / 19\end{array}$ & $\mathrm{n} / \mathrm{a}$ & $\mathrm{n} / \mathrm{a}$ & $\mathrm{n} / \mathrm{a}$ & $\mathrm{n} / \mathrm{a}$ & 0.37 & 0.020 & 0.22 & 0.114 \\
\hline $\begin{array}{c}12 / 26- \\
12 / 26\end{array}$ & $\mathrm{n} / \mathrm{a}$ & $\mathrm{n} / \mathrm{a}$ & $\mathrm{n} / \mathrm{a}$ & $\mathrm{n} / \mathrm{a}$ & $\mathrm{n} / \mathrm{a}$ & $\mathrm{n} / \mathrm{a}$ & $\mathrm{n} / \mathrm{a}$ & $\mathrm{n} / \mathrm{a}$ \\
\hline
\end{tabular}

${ }^{\mathrm{a}}$ Index of association $(X)$ with its associated $P$ value $\left(P_{\mathrm{t}}\right)$ in parenthesis. For a two-tail test at 95\% confidence level, $P_{\mathrm{t}}$ $<0.025$ indicates significant positive association and $P_{\mathrm{t}}>0.975$ indicates significant negative association. Significant associations are in bold. n/a listed when SADIE could not be conducted ( 0 individuals found). 
Table 7. SADIE statistics for the spatial distribution of $H$. halys found at noon

\begin{tabular}{|c|c|c|c|c|}
\hline Date & Average \# & SD & $I_{\mathrm{a}}{ }^{\mathrm{a}}$ & $\mathrm{P}_{\mathrm{a}}$ \\
\hline $9 / 30 / 2013$ & 1.09 & 1.809 & 1.02 & 0.401 \\
\hline $10 / 10 / 2013$ & 2.30 & 4.440 & 0.95 & 0.488 \\
\hline $10 / 18 / 2013$ & 6.24 & 17.339 & 1.27 & 0.156 \\
\hline $10 / 29 / 2013$ & 2.00 & 5.772 & 1.56 & 0.022 \\
\hline $11 / 5 / 2013$ & 0.76 & 2.398 & 0.92 & 0.520 \\
\hline $11 / 12 / 2013$ & 0.94 & 1.886 & 0.97 & 0.452 \\
\hline $11 / 19 / 2013$ & 0.42 & 1.032 & 0.94 & 0.505 \\
\hline $11 / 26 / 2013$ & 0.33 & 0.692 & 0.81 & 0.674 \\
\hline $12 / 3 / 2013$ & 0.42 & 0.708 & 1.22 & 0.211 \\
\hline $12 / 10 / 2013$ & 0.30 & 0.637 & 1.33 & 0.141 \\
\hline $12 / 18 / 2013$ & 0.03 & 0.174 & $\mathrm{n} / \mathrm{a}$ & $\mathrm{n} / \mathrm{a}$ \\
\hline $12 / 26 / 2013$ & 0.03 & 0.174 & $\mathrm{n} / \mathrm{a}$ & $\mathrm{n} / \mathrm{a}$ \\
\hline $10 / 1 / 2014$ & 6.64 & 13.012 & 0.99 & 0.436 \\
\hline $10 / 16 / 2014$ & 1.48 & 4.101 & 1.04 & 0.387 \\
\hline $10 / 20 / 2014$ & 0.42 & 1.480 & 1.33 & 0.134 \\
\hline $10 / 30 / 2014$ & 0.33 & 0.924 & 1.18 & 0.223 \\
\hline $11 / 4 / 2014$ & 0.48 & 1.093 & 1.02 & 0.386 \\
\hline $11 / 11 / 2014$ & 1.48 & 4.124 & 0.88 & 0.617 \\
\hline $11 / 22 / 2014$ & 0.27 & 0.674 & 1.14 & 0.262 \\
\hline $11 / 25 / 2014$ & 0.18 & 0.584 & 0.99 & 0.438 \\
\hline $12 / 4 / 2014$ & 0.24 & 0.751 & 1.12 & 0.264 \\
\hline $12 / 12 / 2014$ & 0.39 & 1.273 & 1.16 & 0.253 \\
\hline $12 / 19 / 2014$ & 0.42 & 0.867 & 0.85 & 0.625 \\
\hline $12 / 26 / 2014$ & 0.00 & $\mathrm{n} / \mathrm{a}$ & $\mathrm{n} / \mathrm{a}$ & $\mathrm{n} / \mathrm{a}$ \\
\hline
\end{tabular}

${ }^{a}$ Overall degree of clustering $\left(I_{\mathrm{a}}\right)$ with its associated $P$ value $\left(P_{\mathrm{a}}\right)$ in parenthesis. $I_{\mathrm{a}}=1$ suggests a random, $I_{\mathrm{a}}>1$ suggests an aggregated, and $I_{\mathrm{a}}<1$ suggests a regular spatial pattern. Significant $(P<0.05)$ associations are in bold. $\mathrm{n} / \mathrm{a}$ listed when SADIE could not be conducted (0 individuals found). 
Table 8. SADIE statistics for the spatial distribution of $H$. halys found in the evening

\begin{tabular}{ccccc}
\hline \hline Date & Average \# & SD & $I_{\mathrm{a}}{ }^{\mathrm{a}}$ & $\mathrm{P}_{\mathrm{a}}$ \\
\hline $9 / 30 / 2013$ & 0.42 & 0.708 & 0.58 & 0.978 \\
$10 / 10 / 2013$ & 1.00 & 1.785 & 0.67 & 0.899 \\
$10 / 18 / 2013$ & 0.94 & 1.321 & 0.63 & 0.942 \\
$10 / 29 / 2013$ & 0.42 & 0.830 & 0.81 & 0.693 \\
$11 / 5 / 2013$ & 0.15 & 0.712 & 1.05 & 0.389 \\
$11 / 12 / 2013$ & 0.45 & 0.617 & 0.82 & 0.673 \\
$11 / 19 / 2013$ & 0.03 & 0.174 & $\mathrm{n} / \mathrm{a}$ & $\mathrm{n} / \mathrm{a}$ \\
$11 / 26 / 2013$ & 0.24 & 0.000 & 0.69 & 0.909 \\
$12 / 3 / 2013$ & 0.00 & 0.566 & $\mathrm{n} / \mathrm{a}$ & 0.94 \\
$12 / 10 / 2013$ & 0.15 & 0.384 & 0.91 & 0.411 \\
$12 / 18 / 2013$ & 0.09 & 0.174 & $\mathrm{n} / \mathrm{a}$ & $\mathrm{n} / \mathrm{a}$ \\
$12 / 26 / 2013$ & 0.03 & 1.223 & 0.94 & 0.485 \\
$10 / 1 / 2014$ & 5.45 & 0.939 & 0.63 & 0.933 \\
$10 / 16 / 2014$ & 0.61 & 1.032 & 0.94 & 0.496 \\
$10 / 20 / 2014$ & 0.52 & 1.822 & 1.18 & 0.230 \\
$10 / 30 / 2014$ & 0.42 & 1.550 & 1.14 & 0.263 \\
$11 / 4 / 2014$ & 0.85 & 0.962 & 1.34 & 0.139 \\
$11 / 11 / 2014$ & 0.82 & 0.584 & 1.10 & 0.306 \\
$11 / 22 / 2014$ & 0.36 & 0.650 & 0.99 & 0.438 \\
$11 / 25 / 2014$ & 0.18 & 1.601 & 1.09 & 0.298 \\
$12 / 4 / 2014$ & 0.21 & 0.822 & 1.05 & 0.387 \\
$12 / 12 / 2014$ & 0.42 & $\mathrm{n} / \mathrm{a}$ & 0.90 & $\mathrm{n} / \mathrm{a}$ \\
$12 / 19 / 2014$ & 0.36 & $\mathrm{n} / \mathrm{a}$ \\
$12 / 26 / 2014$ & 0.00 & $\mathrm{a}$ & 0.551 \\
\hline
\end{tabular}

${ }^{a}$ Overall degree of clustering $\left(I_{\mathrm{a}}\right)$ with its associated $P$ value $\left(P_{\mathrm{a}}\right)$ in parenthesis. $I_{\mathrm{a}}=1$ suggests a random, $I_{\mathrm{a}}>1$ suggests an aggregated, and $I_{\mathrm{a}}<1$ suggests a regular spatial pattern. Significant $(P<0.05)$ associations are in bold. $\mathrm{n} / \mathrm{a}$ listed when SADIE could not be conducted ( 0 individuals found). 
Table 9. SADIE statistics for the spatial distribution of total $H$. halys found

\begin{tabular}{ccccc}
\hline \hline Date & Average $\#$ & SE & $I_{\mathrm{a}} \mathrm{a}^{\mathrm{a}}$ & $\mathrm{P}_{\mathrm{a}}$ \\
\hline $9 / 30 / 2013$ & 1.73 & 2.240 & 1.07 & 0.335 \\
$10 / 10 / 2013$ & 3.91 & 5.150 & 0.97 & 0.458 \\
$10 / 18 / 2013$ & 8.58 & 18.204 & 1.29 & 0.148 \\
$10 / 29 / 2013$ & 2.97 & 5.714 & 1.46 & 0.066 \\
$11 / 5 / 2013$ & 1.30 & 3.087 & 0.82 & 0.679 \\
$11 / 12 / 2013$ & 1.48 & 2.438 & 0.95 & 0.490 \\
$11 / 19 / 2013$ & 0.70 & 1.380 & 1.28 & 0.166 \\
$11 / 26 / 2013$ & 0.79 & 1.596 & 0.96 & 0.462 \\
$12 / 3 / 2013$ & 0.73 & 1.682 & 0.83 & 0.687 \\
$12 / 10 / 2013$ & 0.55 & 1.121 & 1.29 & 0.156 \\
$12 / 18 / 2013$ & 0.15 & 0.619 & 0.99 & 0.375 \\
$12 / 26 / 2013$ & 0.09 & 0.384 & 0.83 & 0.709 \\
$10 / 1 / 2014$ & 15.42 & 25.295 & 0.83 & 0.674 \\
$10 / 16 / 2014$ & 2.85 & 6.011 & 0.85 & 0.643 \\
$10 / 20 / 2014$ & 1.61 & 3.579 & 1.03 & 0.382 \\
$10 / 30 / 2014$ & 1.09 & 2.638 & 1.19 & 0.223 \\
$11 / 4 / 2014$ & 1.58 & 3.354 & 1.22 & 0.202 \\
$11 / 11 / 2014$ & 2.88 & 5.600 & 0.97 & 0.454 \\
$11 / 22 / 2014$ & 0.94 & 2.461 & 1.20 & 0.214 \\
$11 / 25 / 2014$ & 0.58 & 1.768 & 1.05 & 0.354 \\
$12 / 4 / 2014$ & 0.73 & 2.111 & 1.09 & 0.281 \\
$12 / 12 / 2014$ & 1.21 & 4.263 & 1.17 & 0.260 \\
$12 / 19 / 2014$ & 1.09 & 2.323 & 0.94 & 0.503 \\
$12 / 26 / 2014$ & 0.00 & $\mathrm{n} / \mathrm{a}$ & $\mathrm{n} / \mathrm{a}$ & $\mathrm{n} / \mathrm{a}$ \\
\hline
\end{tabular}

${ }^{a}$ Overall degree of clustering $\left(I_{\mathrm{a}}\right)$ with its associated $P$ value $\left(P_{\mathrm{a}}\right)$ in parenthesis. $I_{\mathrm{a}}=1$ suggests a random, $I_{\mathrm{a}}>1$ suggests an aggregated, and $I_{\mathrm{a}}<1$ suggests a regular spatial pattern. Significant $(P<0.05)$ associations are in bold. $\mathrm{n} / \mathrm{a}$ listed when SADIE could not be conducted ( 0 individuals found). 

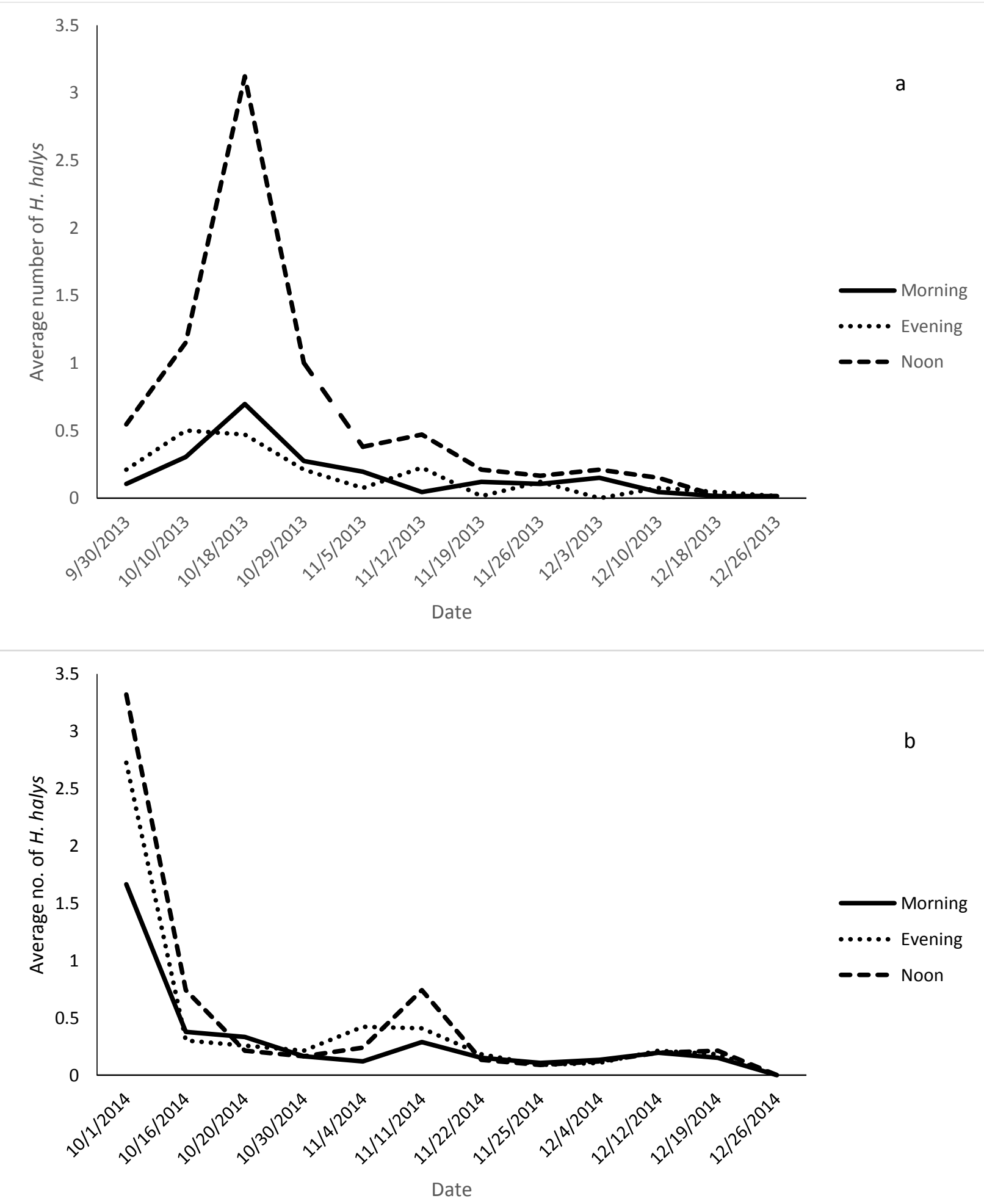

Fig. 1. Average number of $H$. halys observed per year at three different times of day (morning, evening, and noon) in a) 2013, and b) 


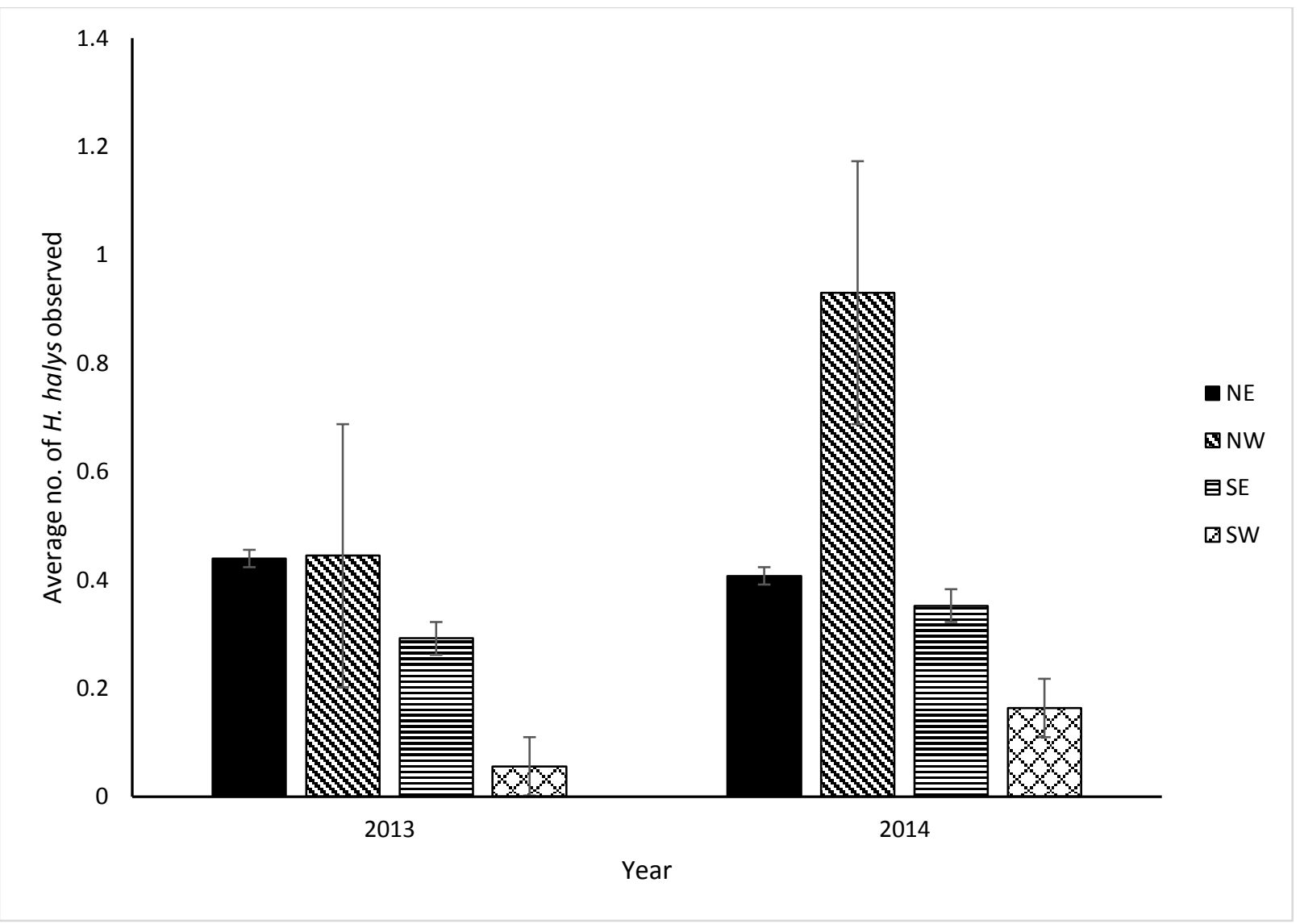

Fig. 2. Average number of $H$. halys observed per surface aspect per year at four different directions: northeast, northwest, southeast, and southwest 
Number of BMSB per surface type

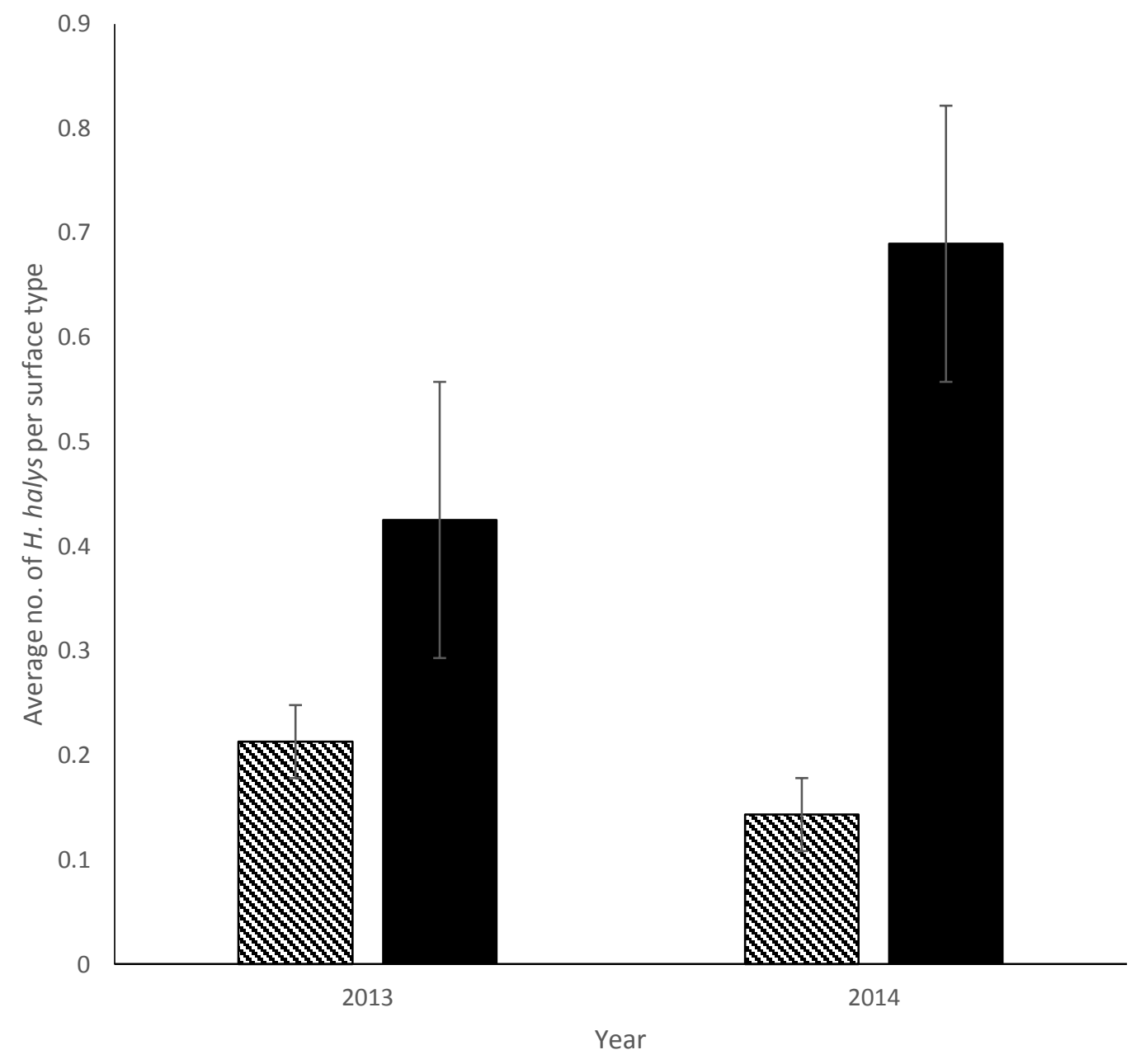

Fig. 3. Average number of $H$. halys observed per year on two surface types: wall and entryway 

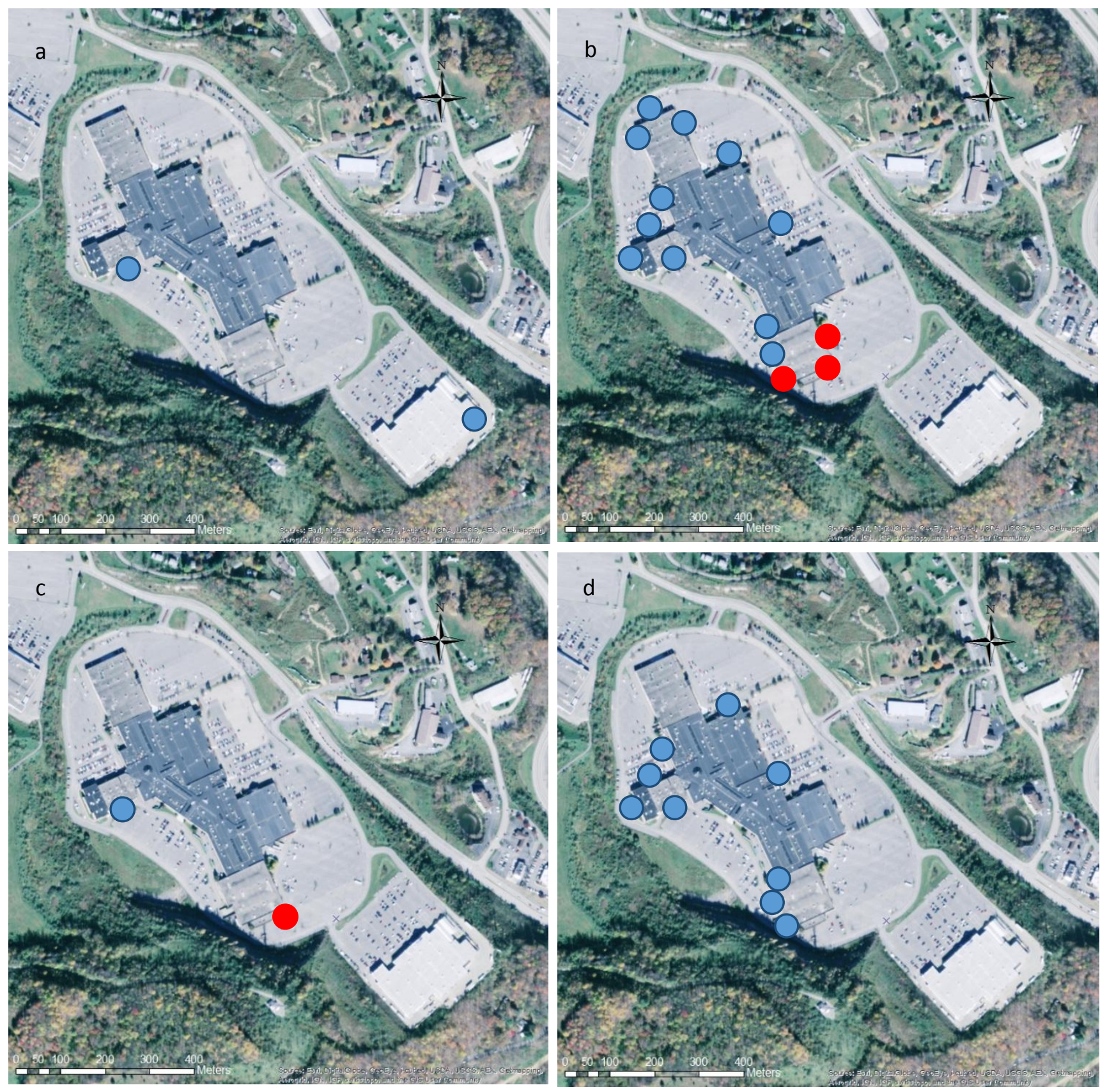

Fig. 4. Maps of patches and gaps in observations of $H$. halys in 2013 in a) morning, b) noon, c) evening, and d) total. Red circles indicate patches with clusters of relatively large counts (i.e., $v_{i}>1.5$ ) and blue circles indicate gaps with clusters of relatively small counts (i.e., $v_{i}<-1.5$ ) 

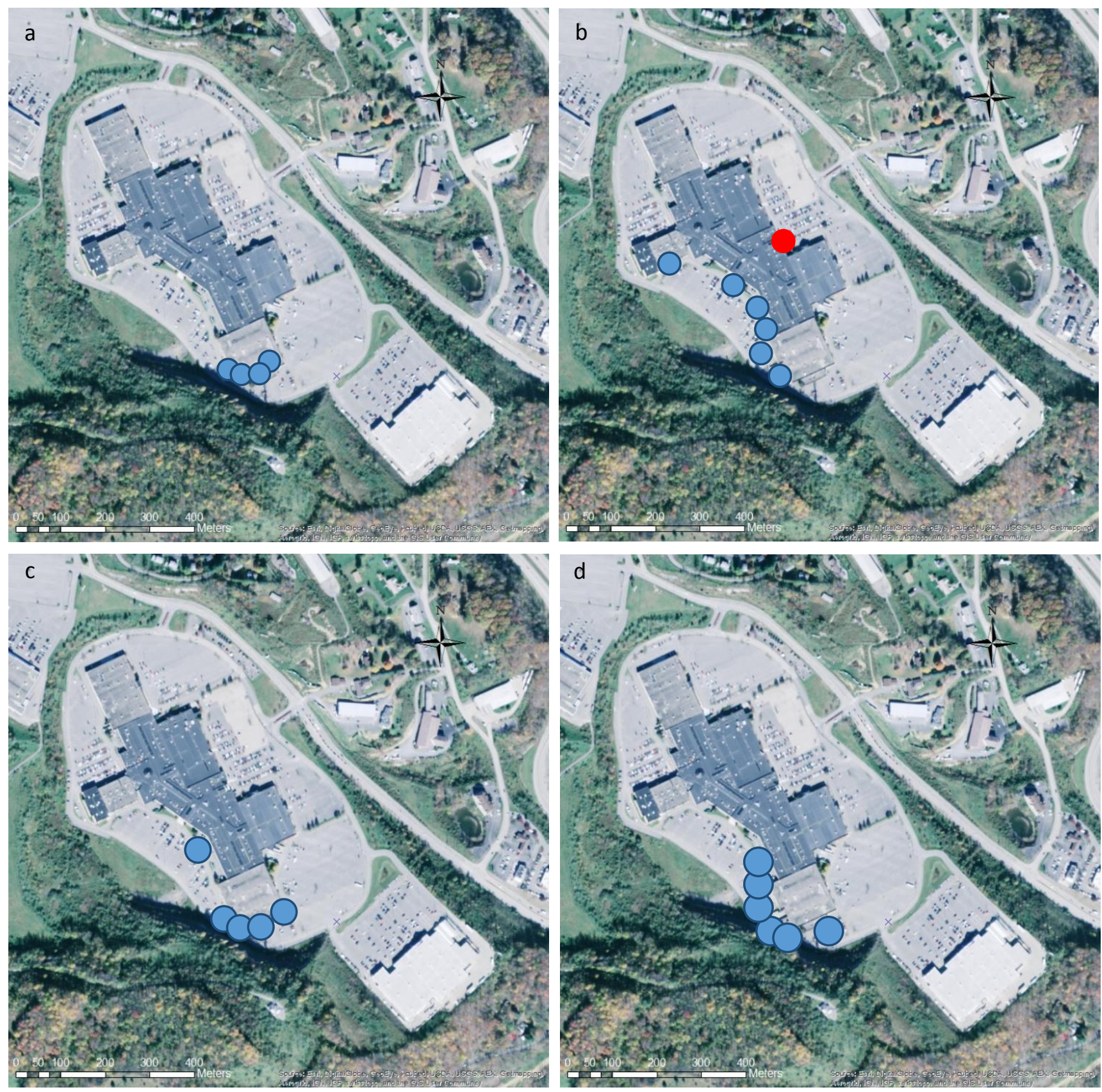

Fig. 5. Maps of patches and gaps in observations of $H$. halys in 2014 in a) morning, b) noon, c) evening, and d) total. Red circles indicate patches with clusters of relatively large counts (i.e., $v_{i}>1.5$ ) and blue circles indicate gaps with clusters of relatively small counts (i.e., $v_{i}<-1.5$ ) 


\section{Chapter 4: Conclusion}

The brown marmorated stink bug, Halyomorpha halys (Hemiptera: Pentatomidae), is an invasive insect colonizing North America. It has steadily spread across at least 41 states in the Mid-Atlantic, the South, and the West Coast causing nuisance problems and economic damage to crops (Jones and Lambdin 2009). H. halys is known to utilize at least 169 host plants, including tree fruits, vegetables, small fruits, and row crops, with Mid-Atlantic apple growers reporting economic losses of over \$37 million (Leskey et al. 2012, Krawczyk and Hull 2011). Additionally, it's highly mobile. Nymphs are capable of walking $10 \mathrm{~m}$ per day to find new host plants (Lee et al. 2014), and adults have flown up to $117 \mathrm{~km}$ in flight mill tests (Lee and Leskey 2015). It's wide range of host plants and high dispersal capacity makes treating infestations on a field-by-field basis challenging, as it is difficult to anticipate which crops will harbor the greatest population densities (Leskey and Hamilton 2010). Alternative, or complementary approaches are needed to combat this insect on a large spatial scale.

The results of this study (Chapter 2) aid understanding of the annual spatial patterns of $H$. halys. Count data across three sites were paired with geo-coordinates to perform spatial analysis by distance indices (SADIE) to characterize spatial distribution patterns and spatial associations of $H$. halys with commodities. Crops bearing the largest numbers of $H$. halys included pears, apples, cherries, peaches, and berries. Overall, H. halys was randomly distributed over the commodity types throughout the growing season. Significant spatial patterns consisted of large gaps with relatively low populations of $H$. halys. However patches of relatively high populations were observed on trees, wild blackberry, corn, and peppers.

This study (Chapter 3) also considers H. halys populations as they move to overwintering habitats in urban environments. While there is no risk of economic damage, large numbers of $H$. halys congregate at overwintering sites such as barns, garages and houses. Understanding this insect's overwintering habits can assist in control by removing large numbers of adults before they can reproduce. We surveyed the outer walls and entryways of a shopping center for $H$. halys as they moved to overwintering sites. H. halys did have a preference for northwest-facing surfaces, and was more highly concentrated on entryways. Combining these findings with the results of spatial analysis suggests that the most effective plan for managing $H$. halys as it moves into human-made overwintering sites is to focus on entryways during the first weeks of October, 
and again in the middle of November. By doing this, the largest number of insects can be affected by management efforts.

This study showed that $H$. halys displays a random spatial distribution at the farm scale, with positive spatial associations occurring in the middle and end of the growing season. Additionally, this study showed that $H$. halys in urban habitats tend to congregate around entryways during the first weeks of October, and again in the middle of November. These findings suggest that by focusing management on specific areas at key times of the year, more efficient control of $H$. halys can be achieved.

\section{Literature Cited}

Jones, J. R., and P. L. Lambdin. 2009. New county and state records for Tennessee of an exotic pest, Halyomorpha halys (Hemiptera: Pentatomidae), with potential economic and ecological implications. Fla. Entomol. 92: 177-178.

Krawczyk, G., and L. Hull. 2011. Management options for the control of brown marmorated stink bug a Pennsylvania perspective, pp. 1-5. In Penn State University Extension (eds.), Fruit times, College Park, PA.

Lee, D. H., A. L. Nielsen, and T. C. Leskey. 2014. Dispersal capacity and behavior of nymphal stages of Halyomorpha halys (Hemiptera: Pentatomidae) evaluated under laboratory and field conditions. J. Insect Behav. 27: 639-651.

Lee, D. H. 2015. Current status of research progress on the biology and management of Halyomorpha halys (Hemiptera: Pentatomidae) as an invasive species. Appl. Entomol Zool. 50: $277-290$.

Lee, D. H., and T. C. Leskey. 2015. Flight behavior of foraging and overwintering brown marmorated stink bug, Halyomorpha halys (Hemiptera: Pentatomidae). Bull. Entomol. Res. 105: 566-573. 
Leskey, T. C., B. D. Short, B. R. Butler, and S. E. Wright. 2012. Impact of the invasive brown marmorated stink bug, Halyomorpha halys (Stål), in Mid-Atlantic tree fruit orchards in the United States: Case studies of commercial management. Psyche 2012b: 1-14.

Leskey, T. C., and C. G. Hamilton. 2010. Brown marmorated stink bug working group meeting. http://projects.ipmcenters.org/Northeastern/FundedProjects/ReportFiles/Pship2010/Pship201 0-Leskey-ProgressReport-237195.pdf 


\section{Appendix I}

SADIE maps of West Virginia organic farm, Morgantown, West Virginia. Overall degree of clustering $\left(I_{\mathrm{a}}\right)$ with its associated $P$ value $\left(P_{\mathrm{a}}\right) . I_{\mathrm{a}}=1$ suggests a random, $I_{\mathrm{a}}>1$ suggests an aggregated, and $I_{\mathrm{a}}<1$ suggests a regular spatial pattern. Significant $(P<0.05)$ associations are in bold. Red areas indicate patches with clusters of relatively large counts (i.e., $v_{i}>1.5$ ) and blue area indicate gaps with clusters of relatively small counts (i.e., $v_{i}<-1.5$ )

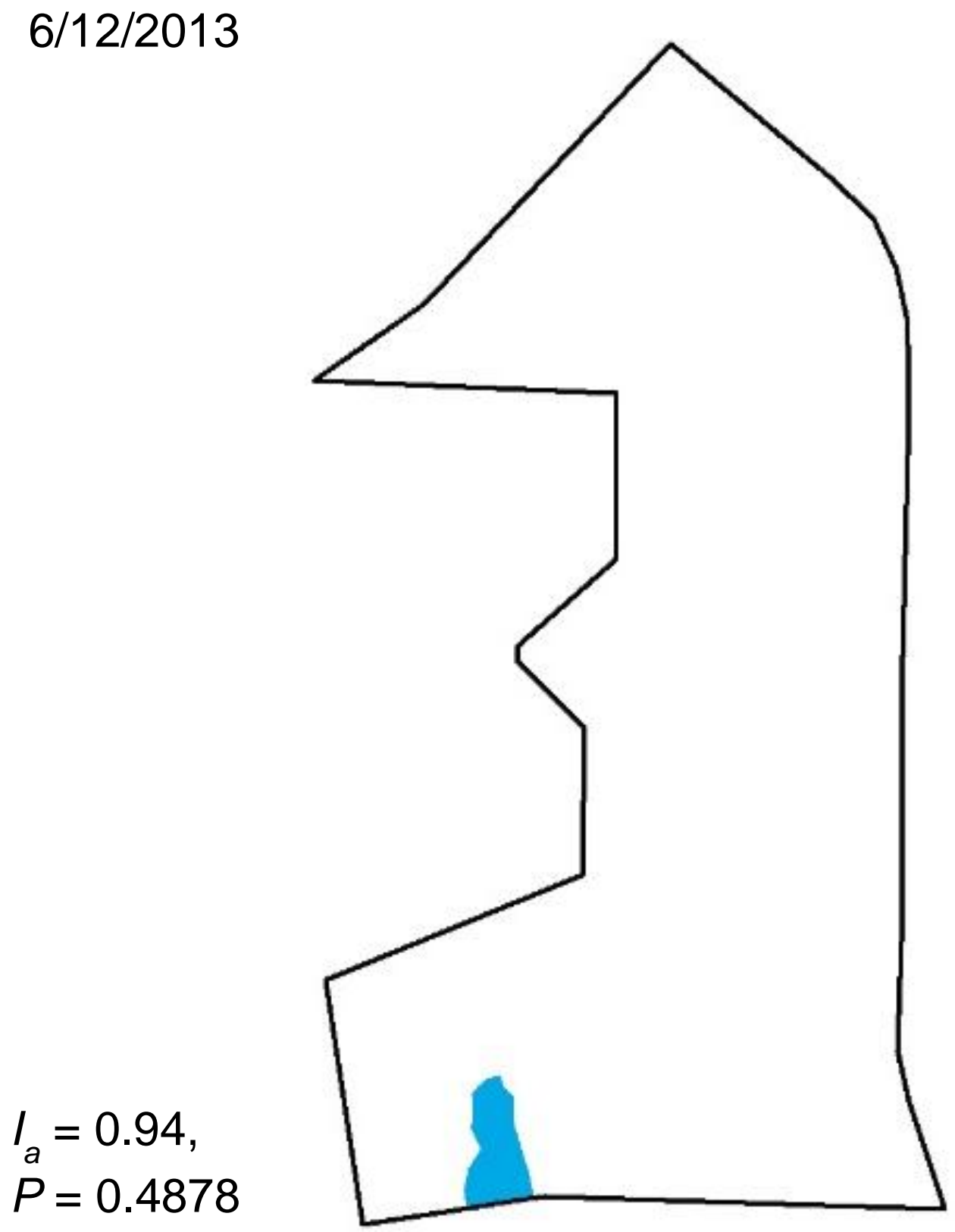



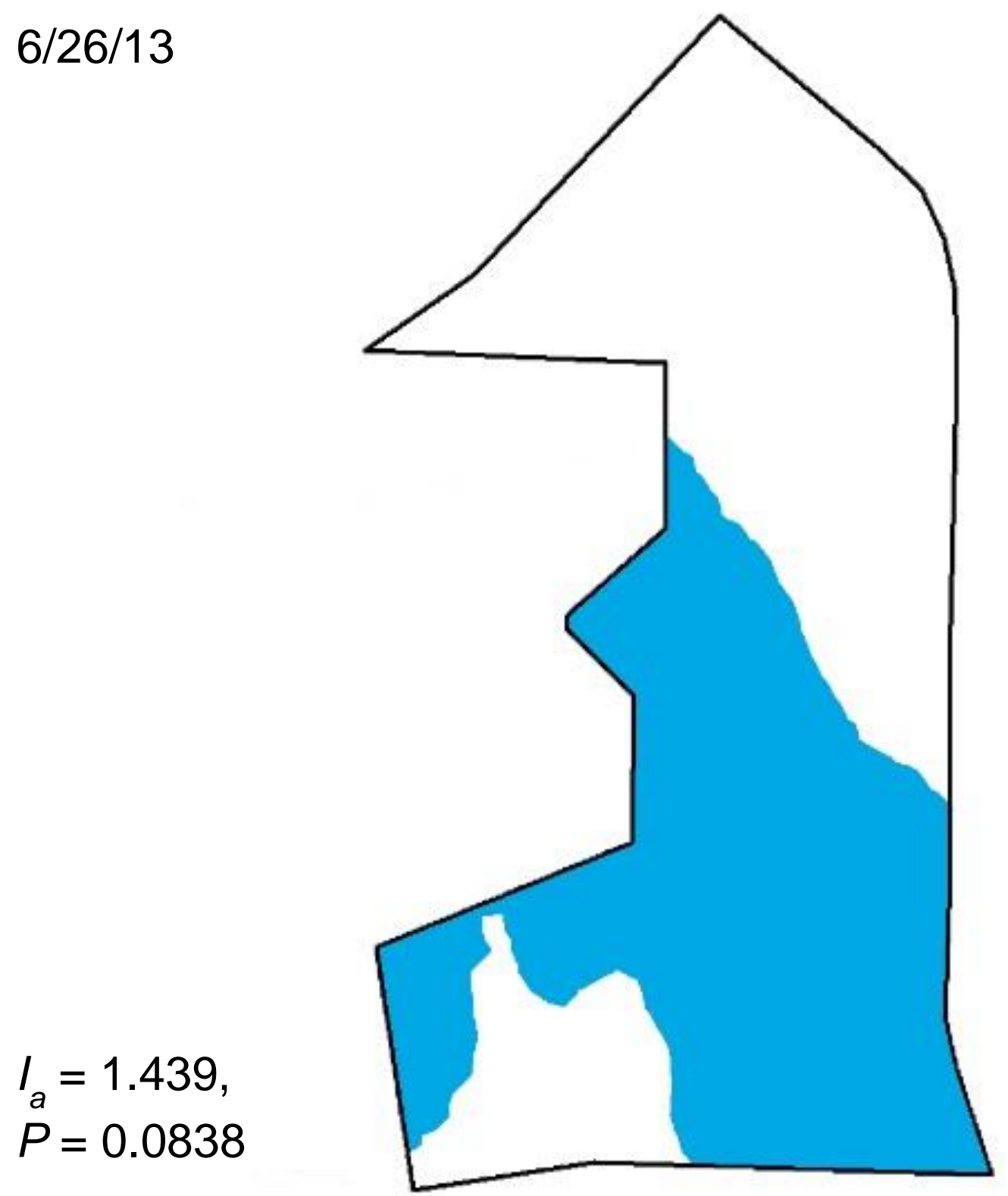


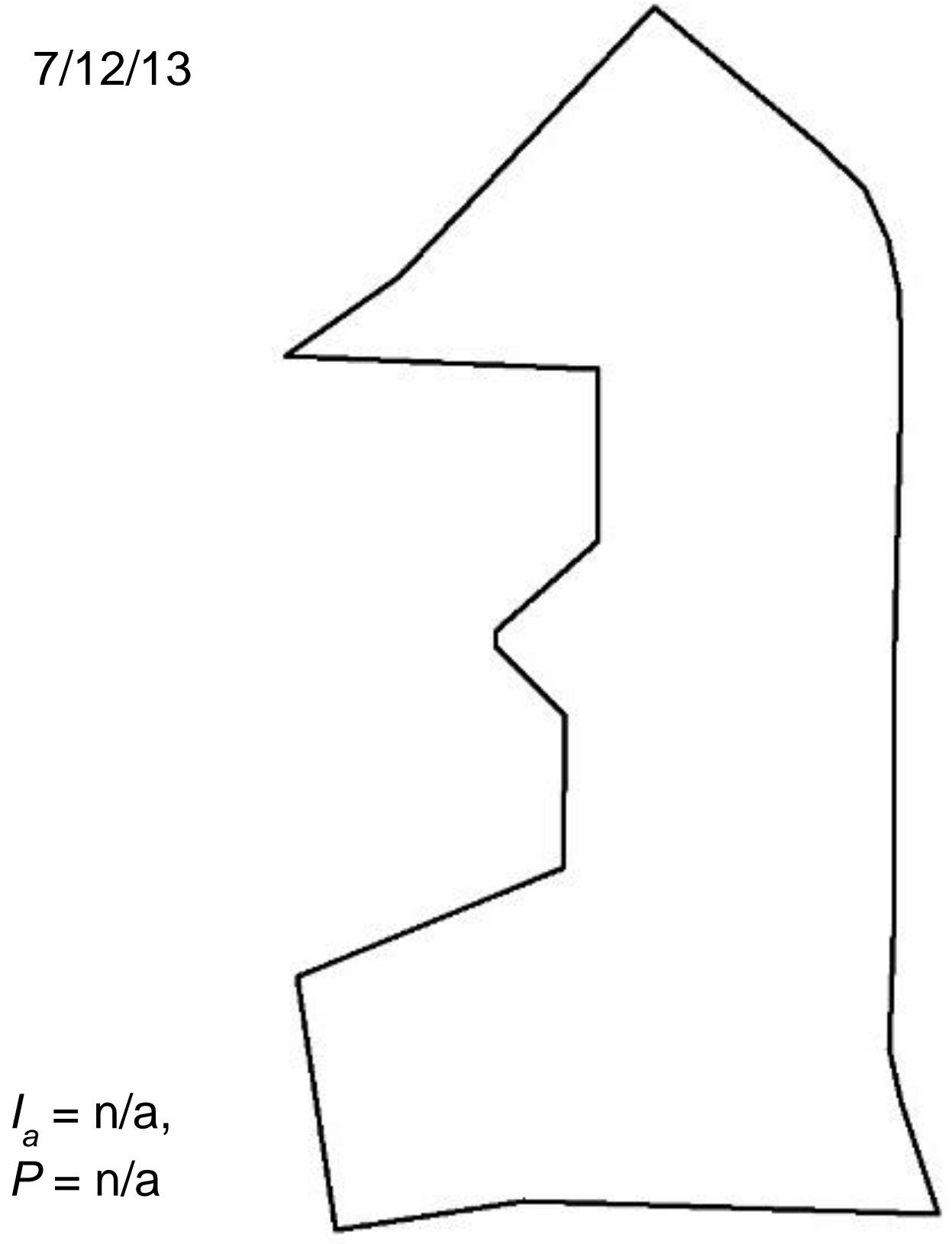




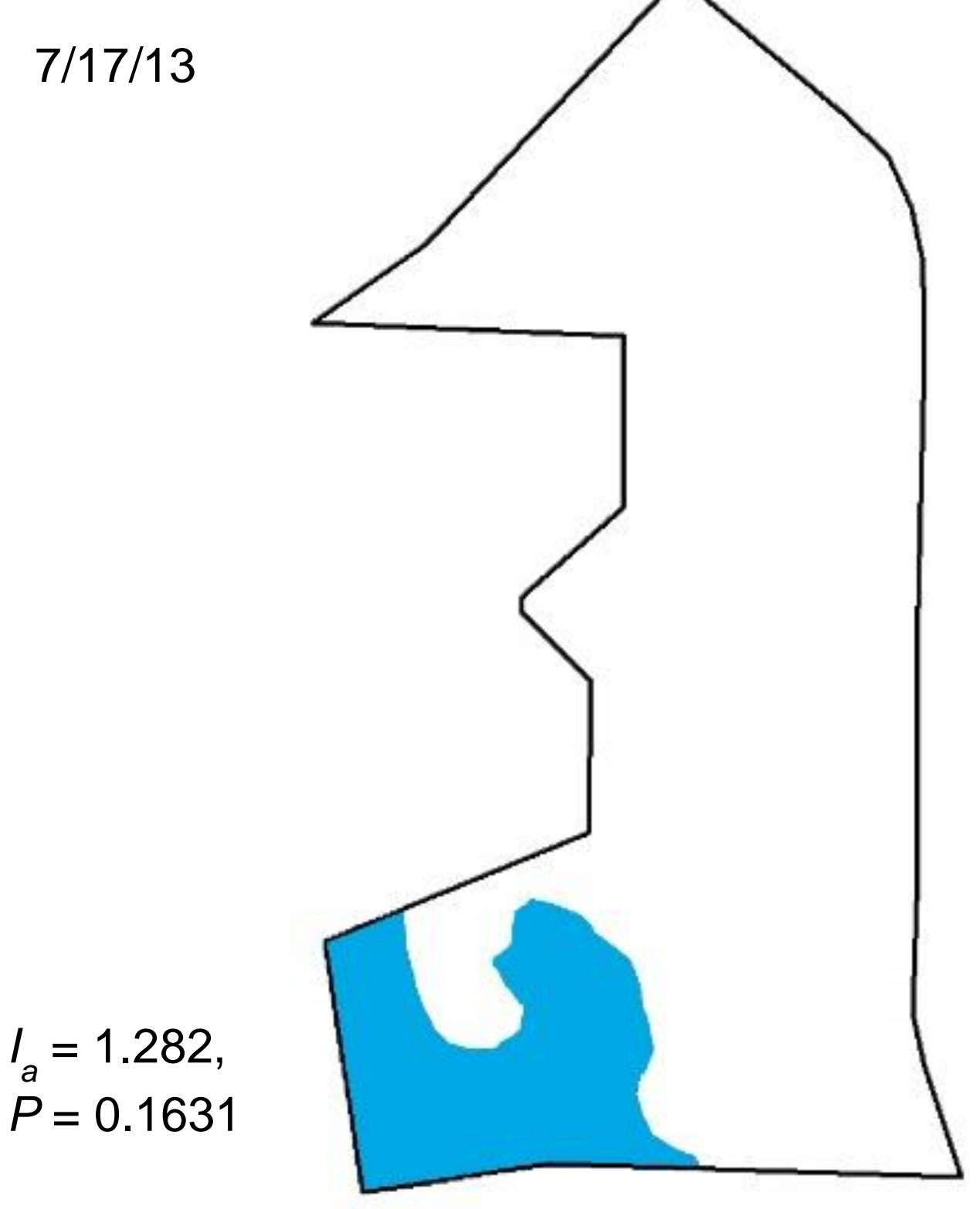




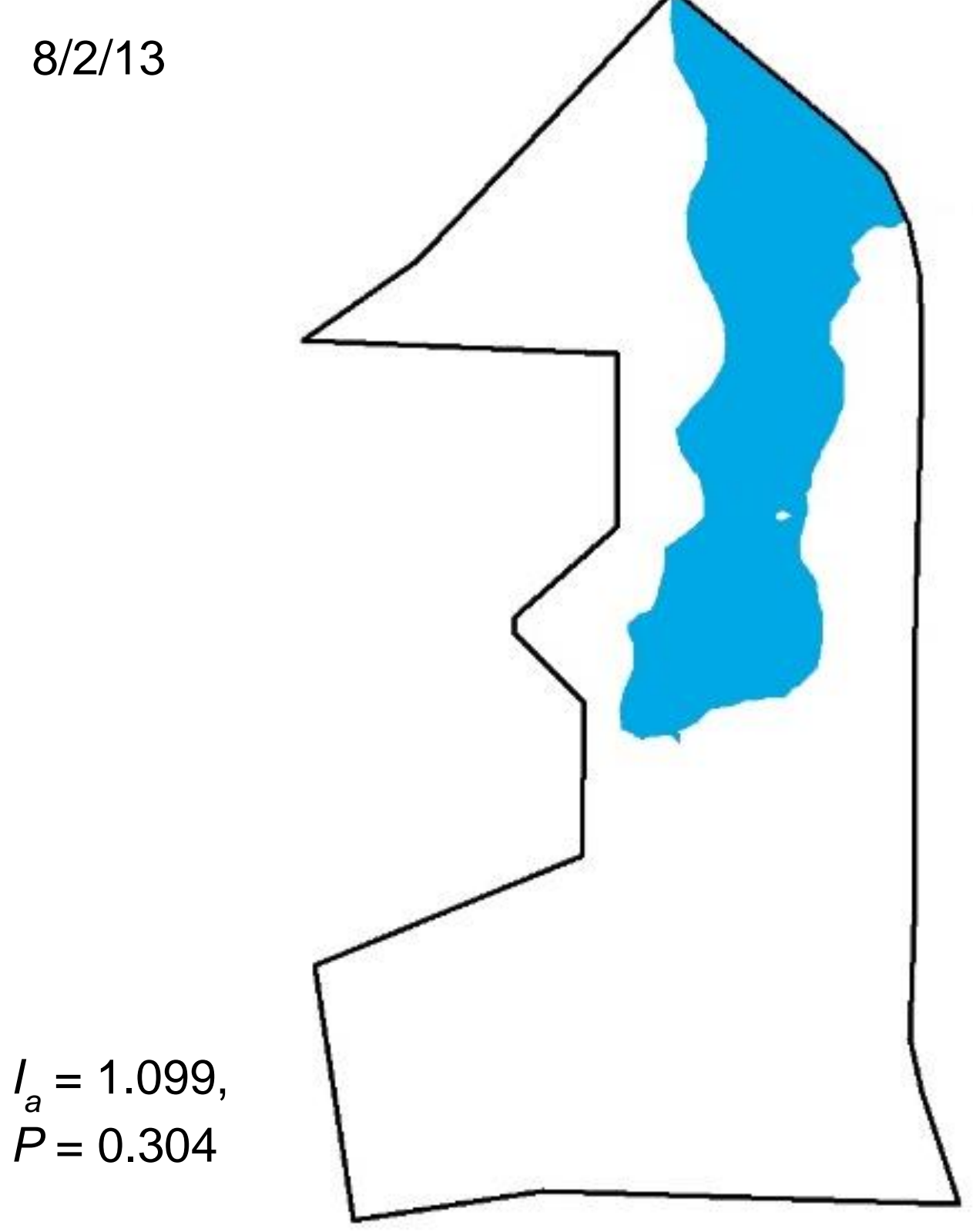


9/9/13

$I_{a}=0.919$,

$P=5465$

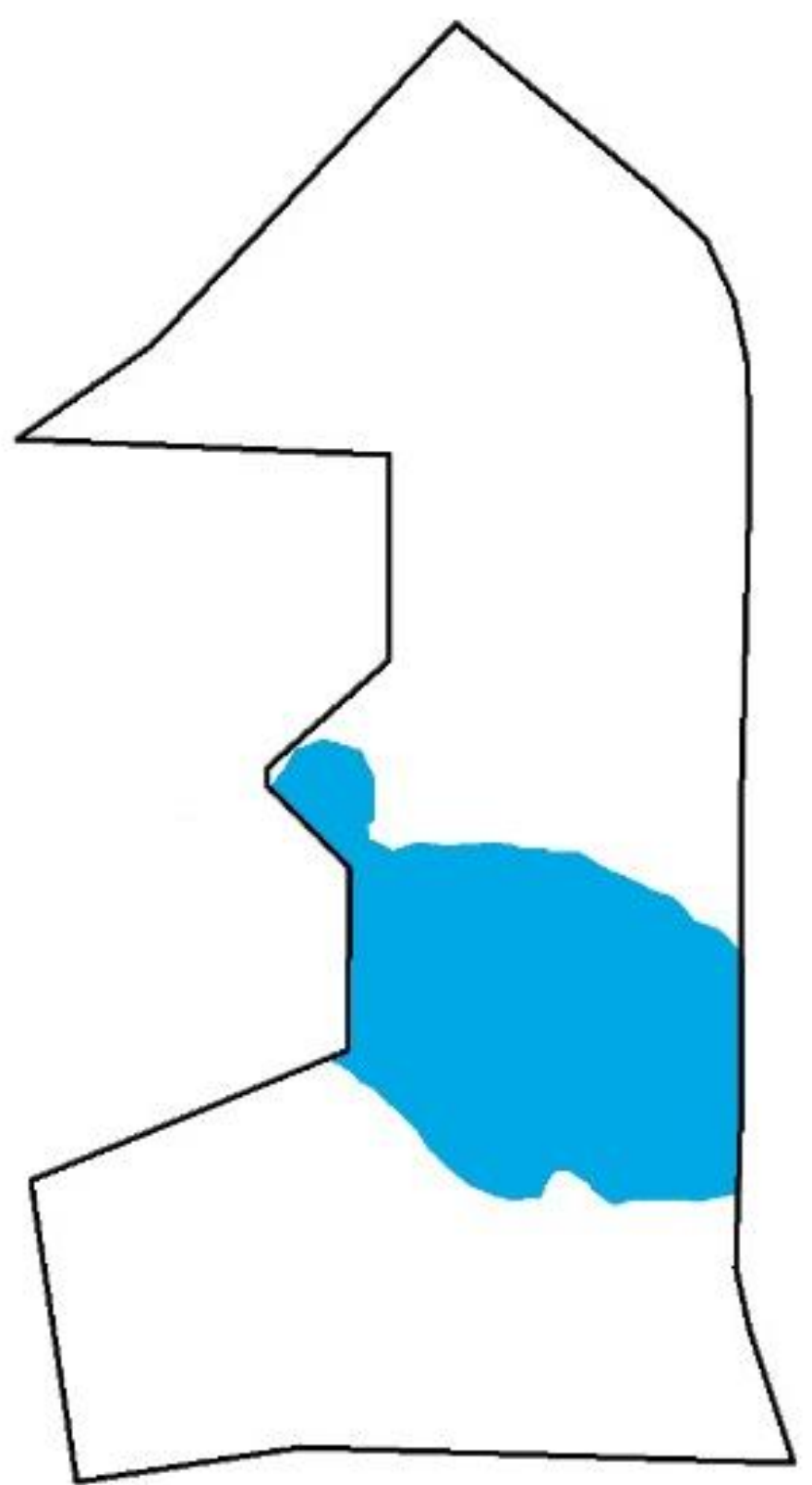



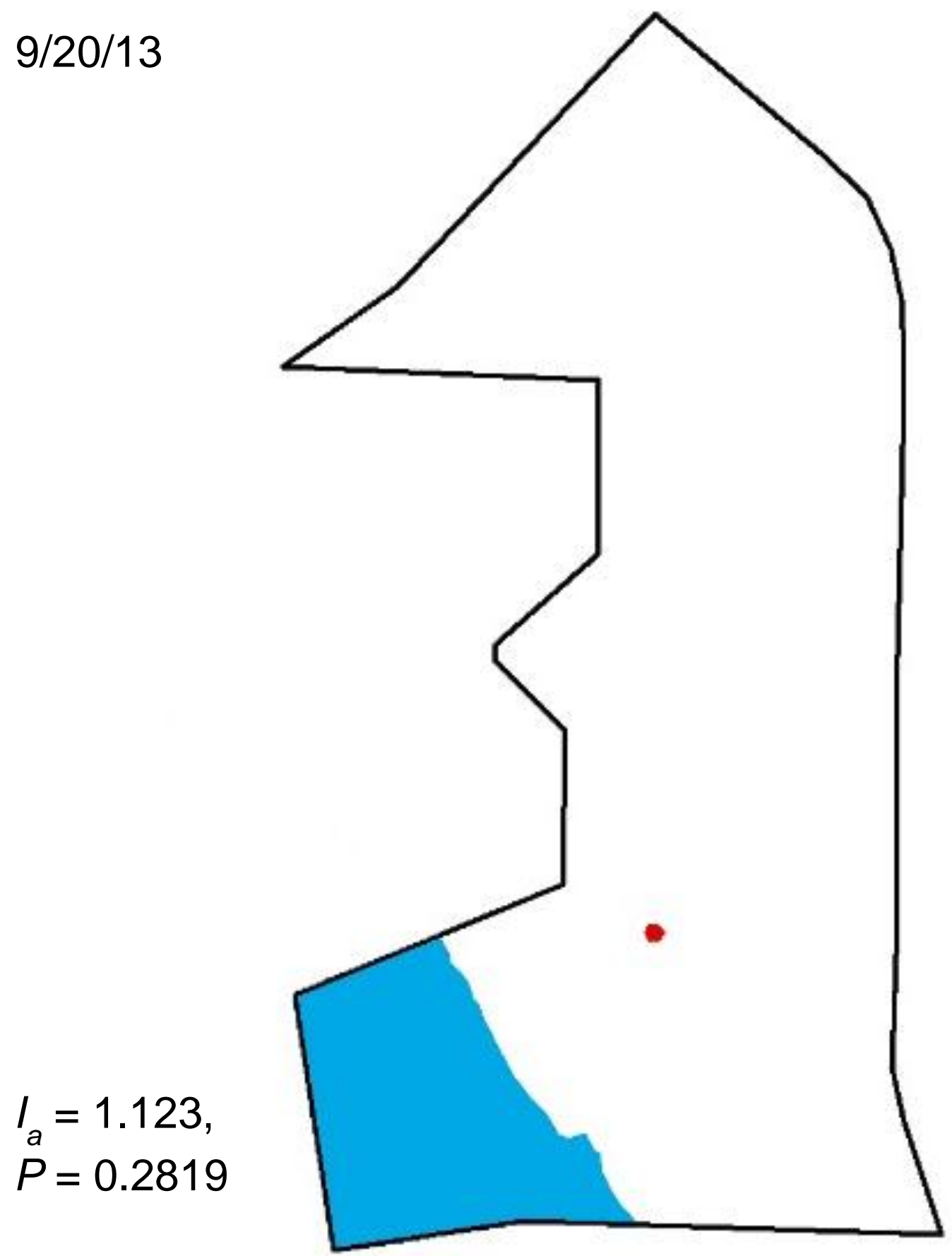


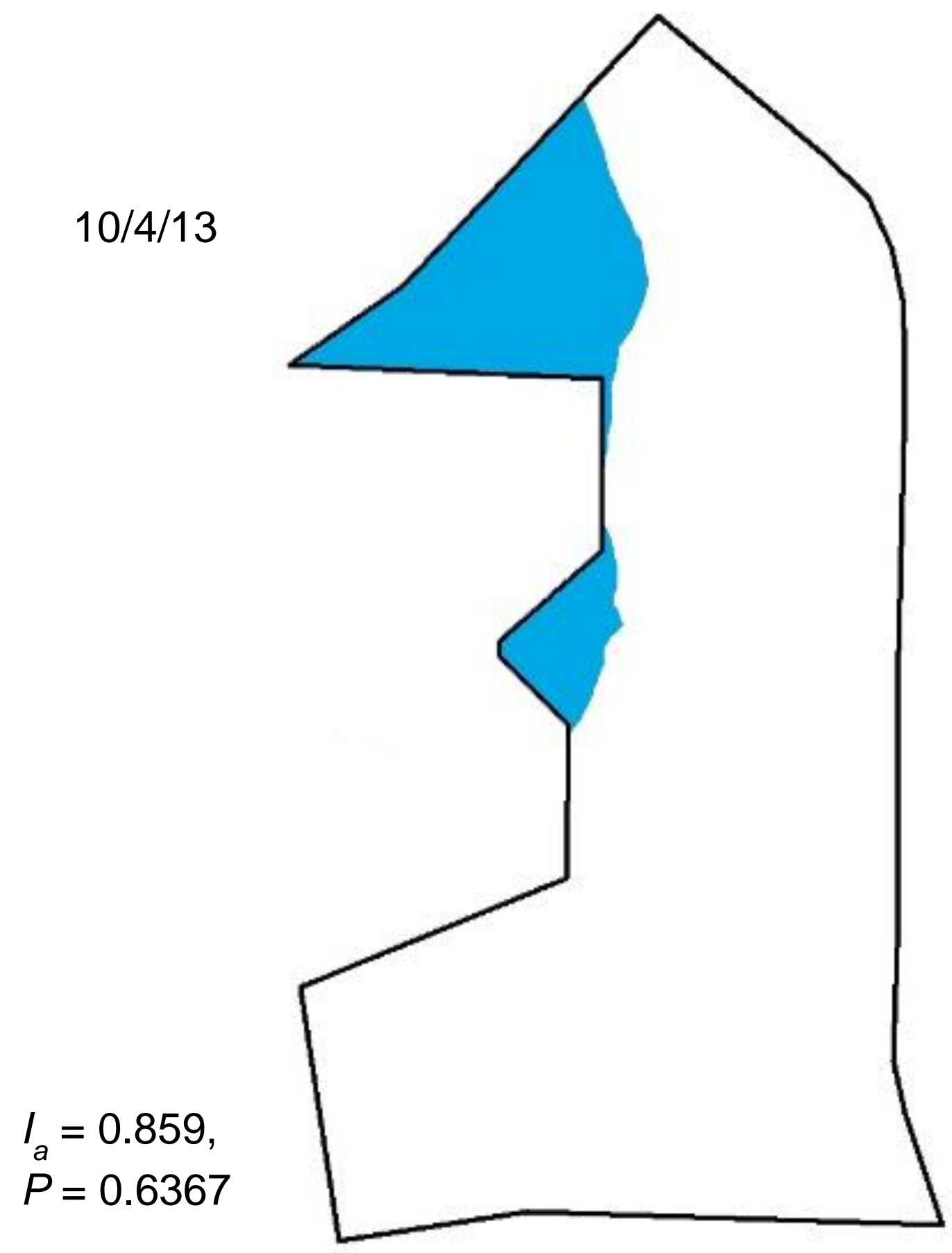




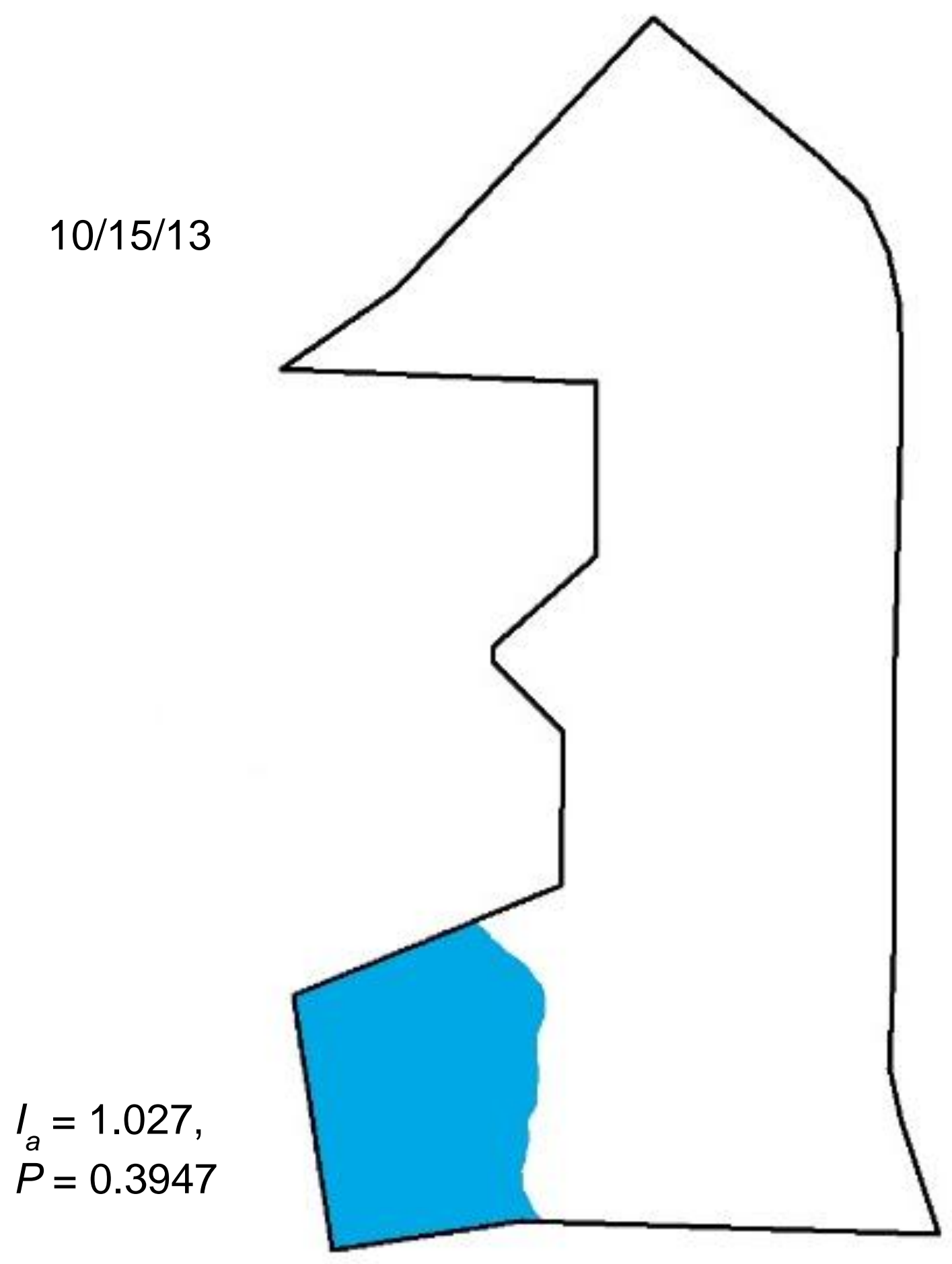




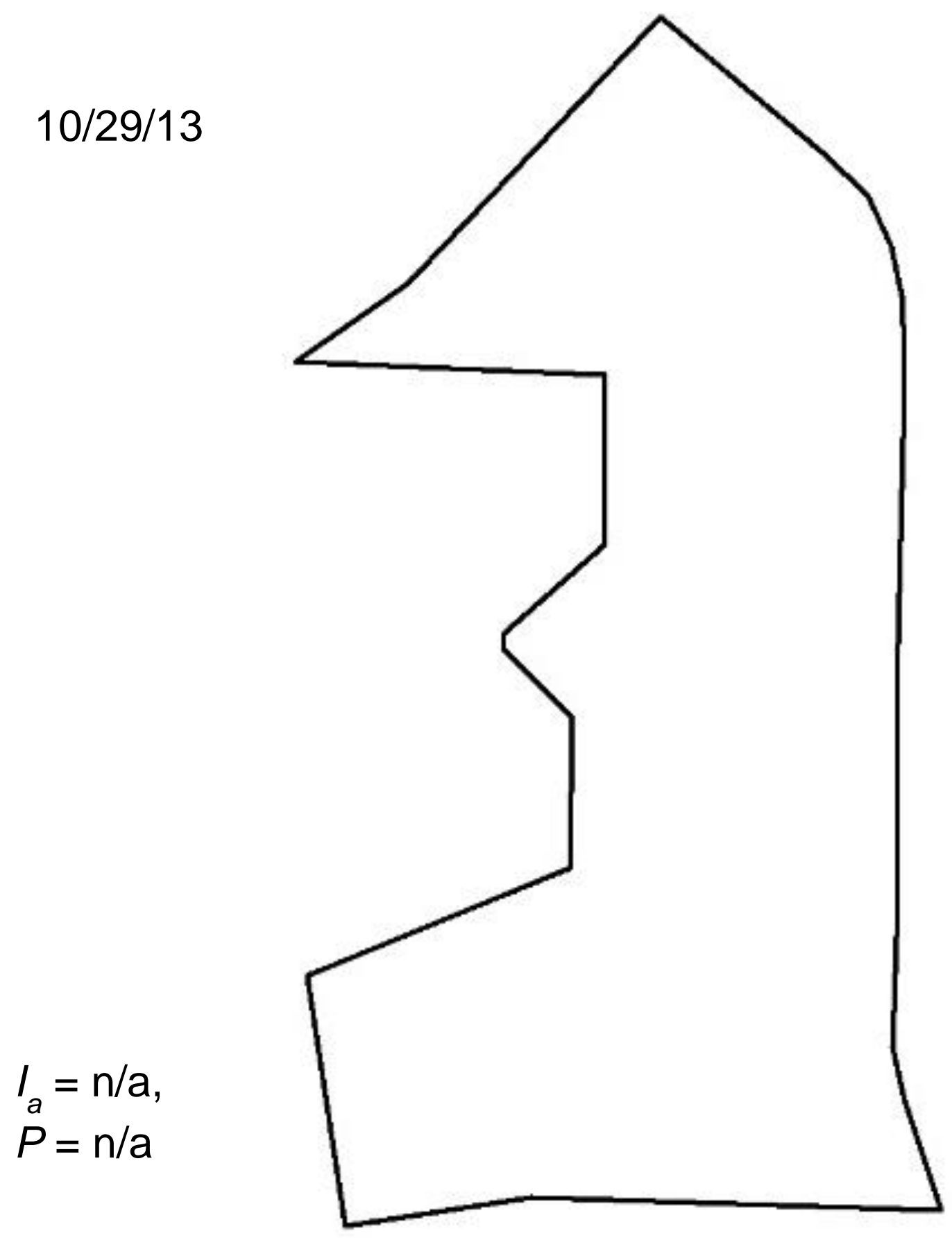




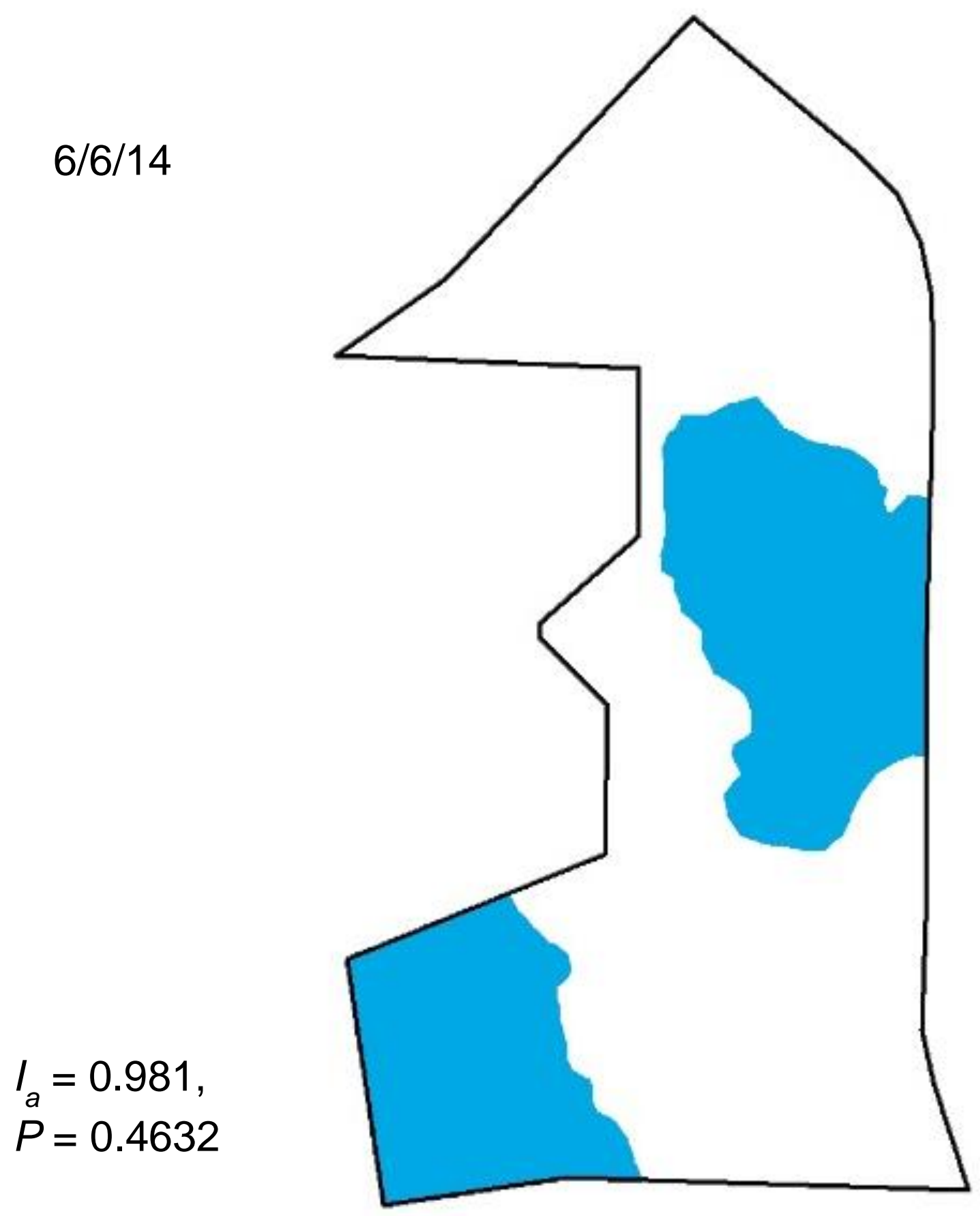




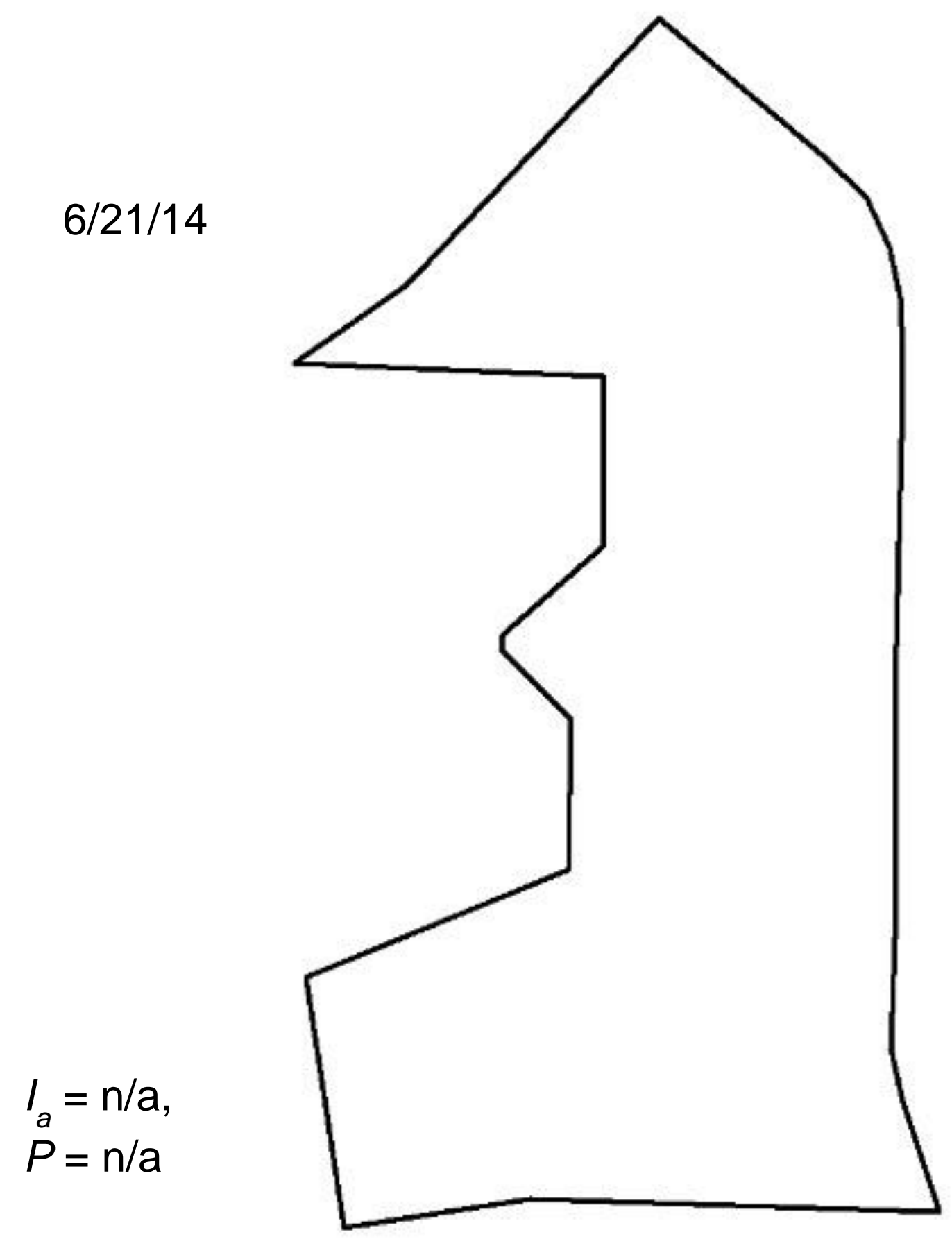




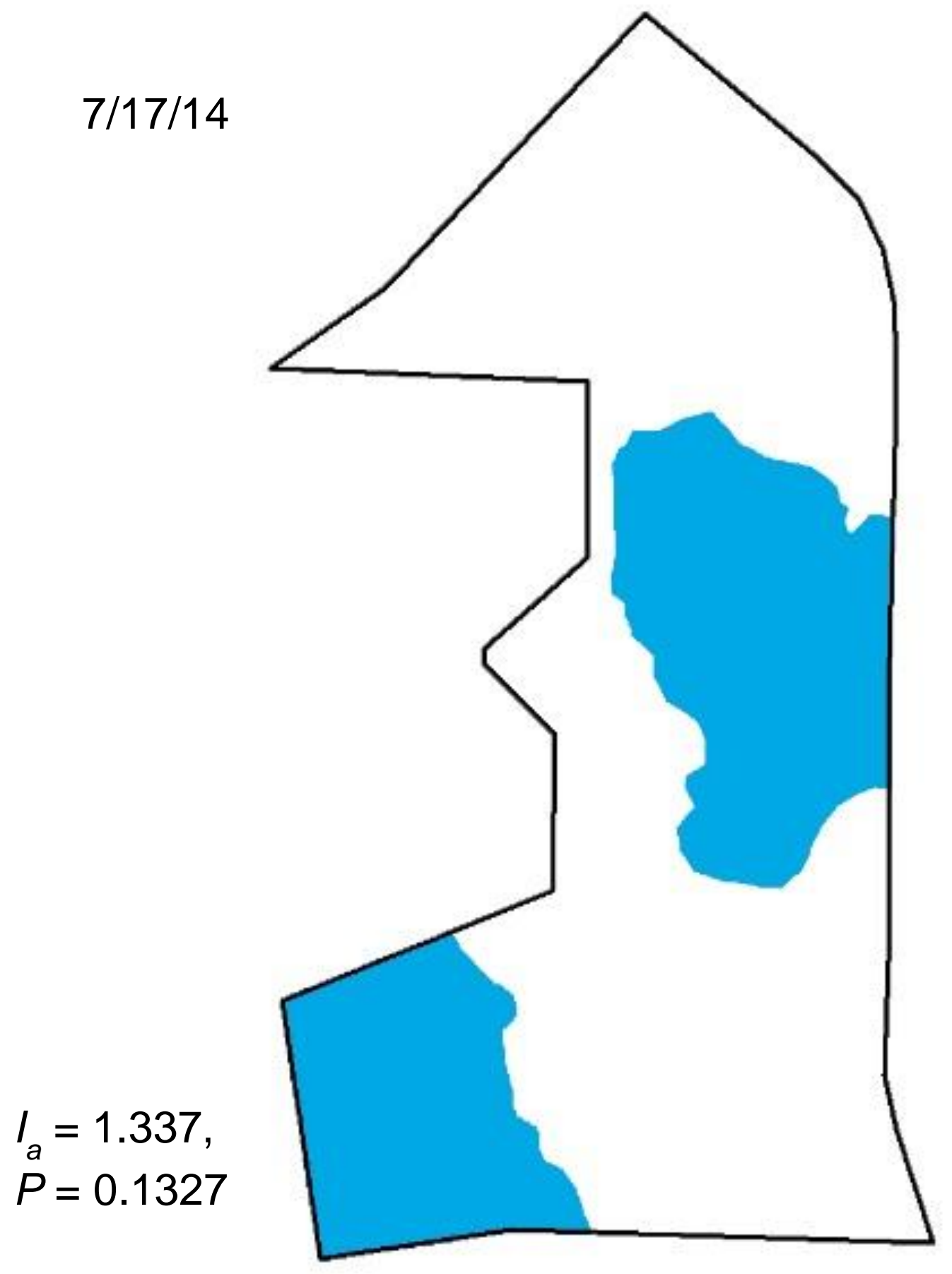




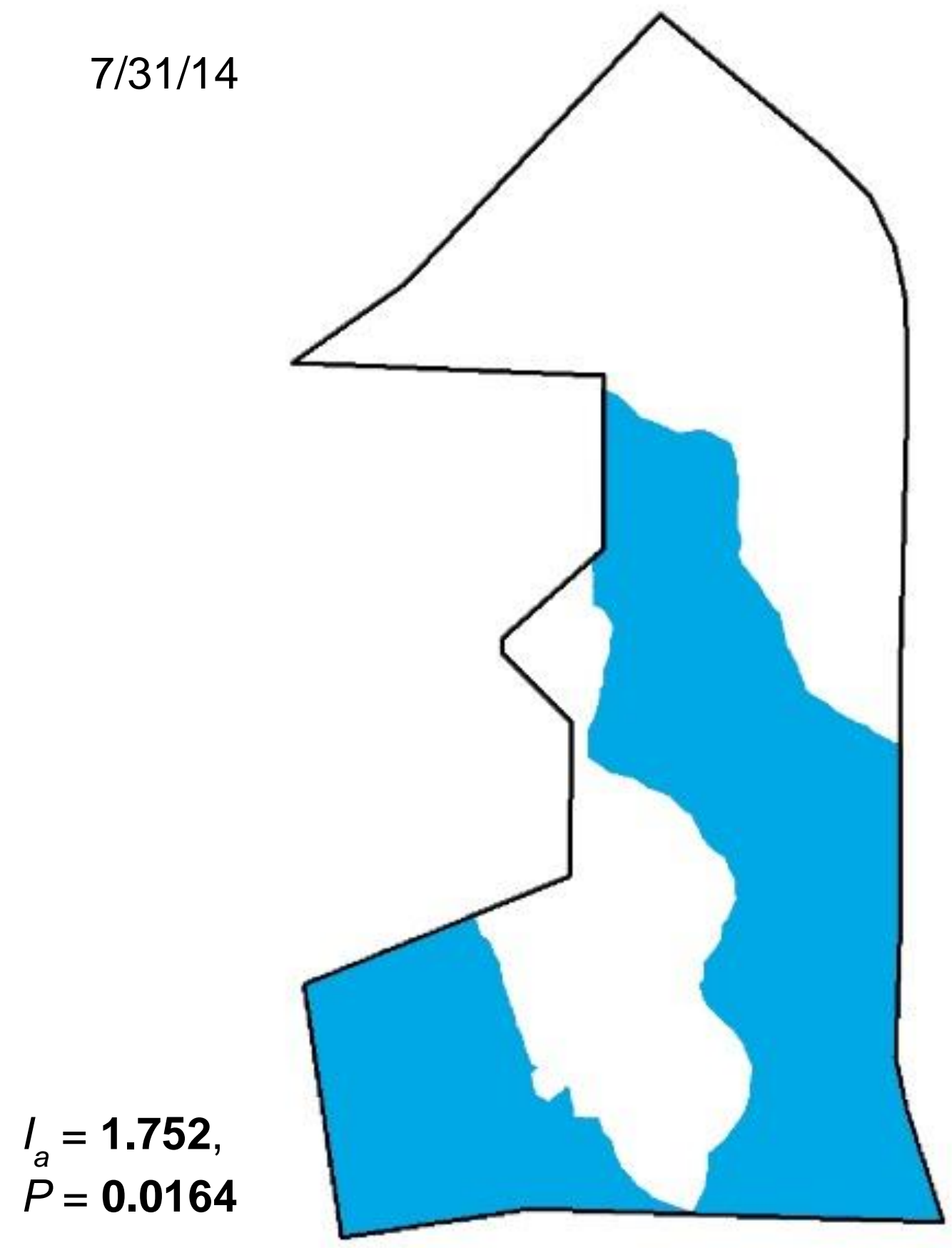




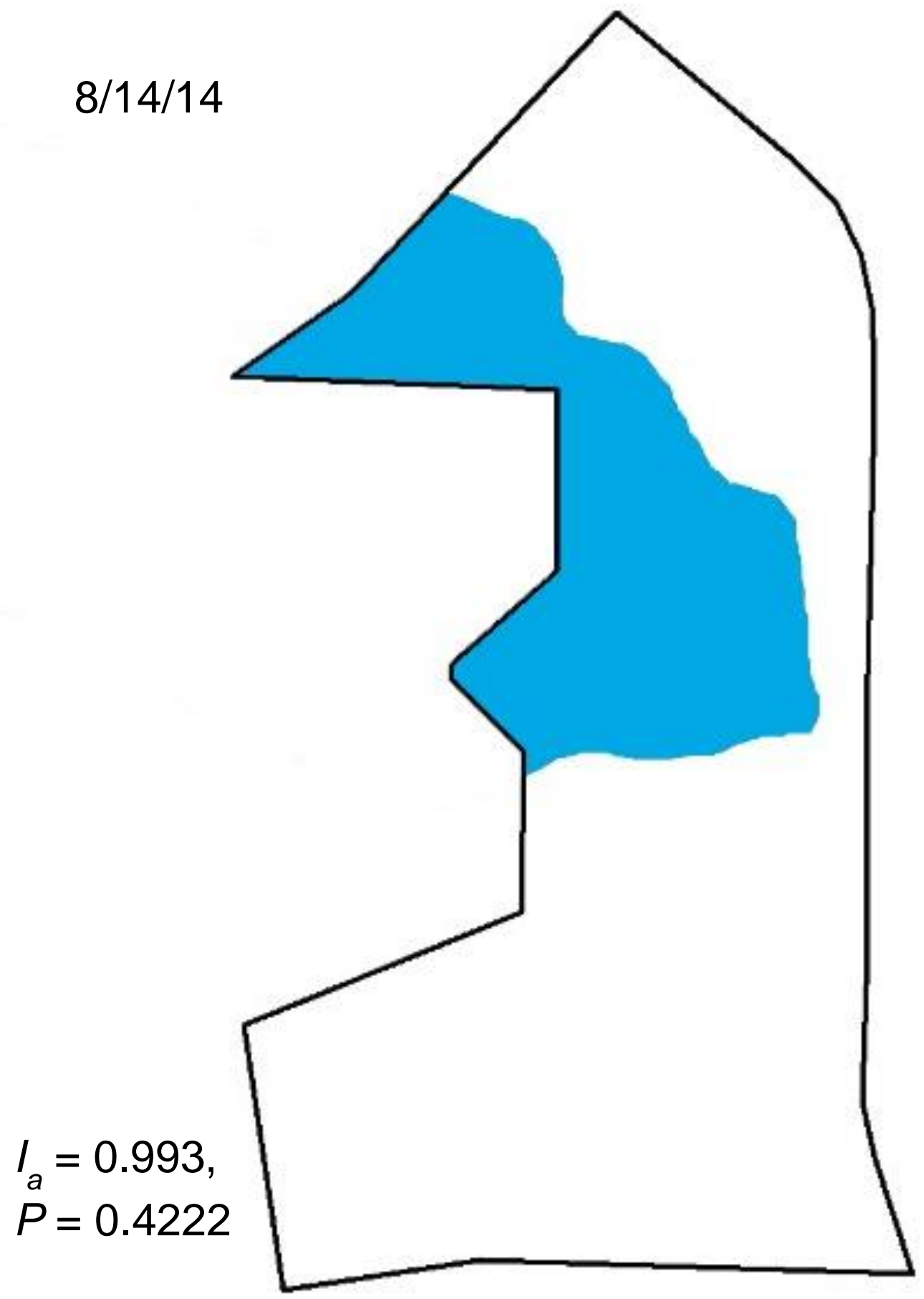




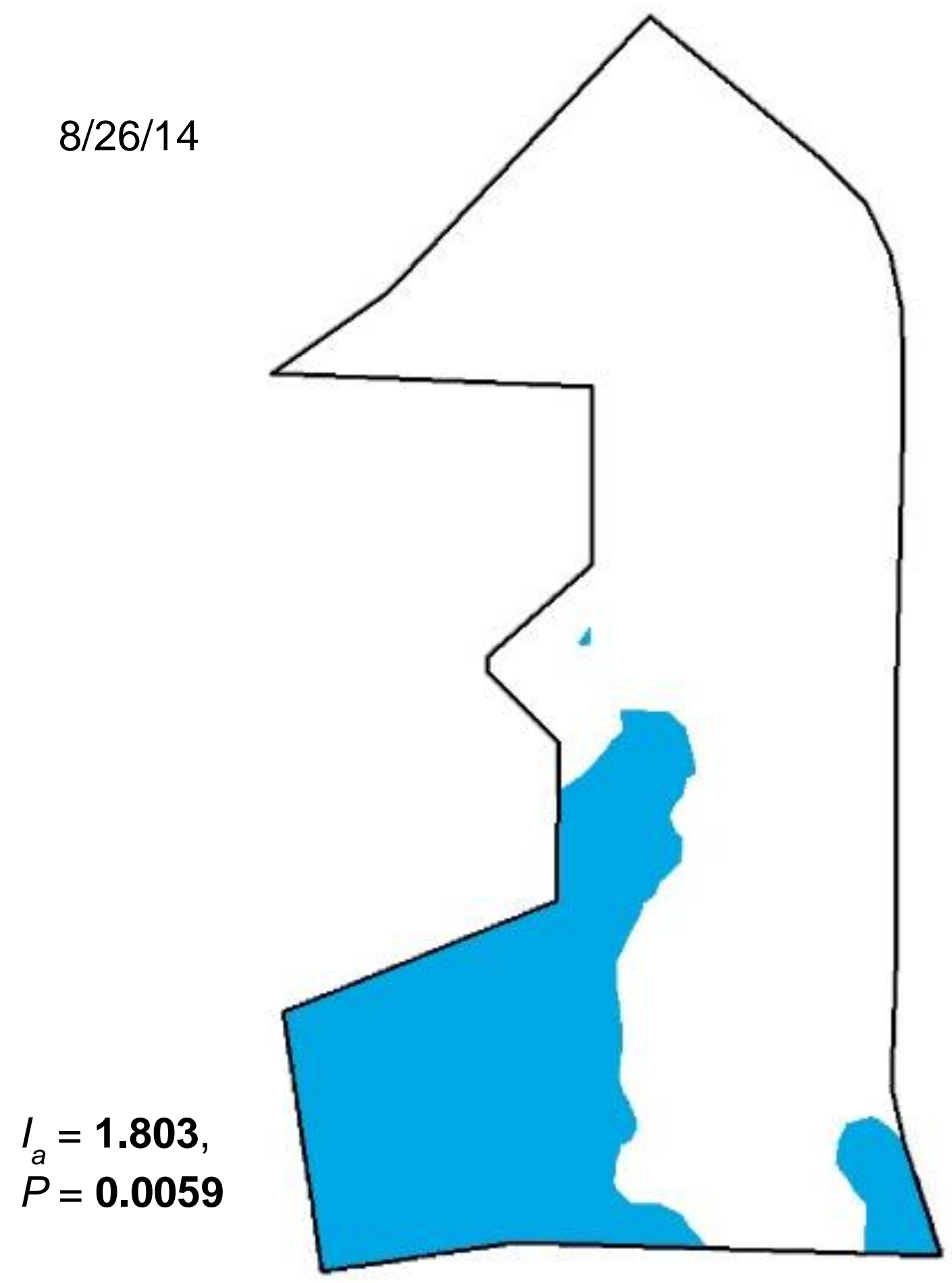


$9 / 9 / 14$

$I_{a}=1.675$
$P=0.0255$

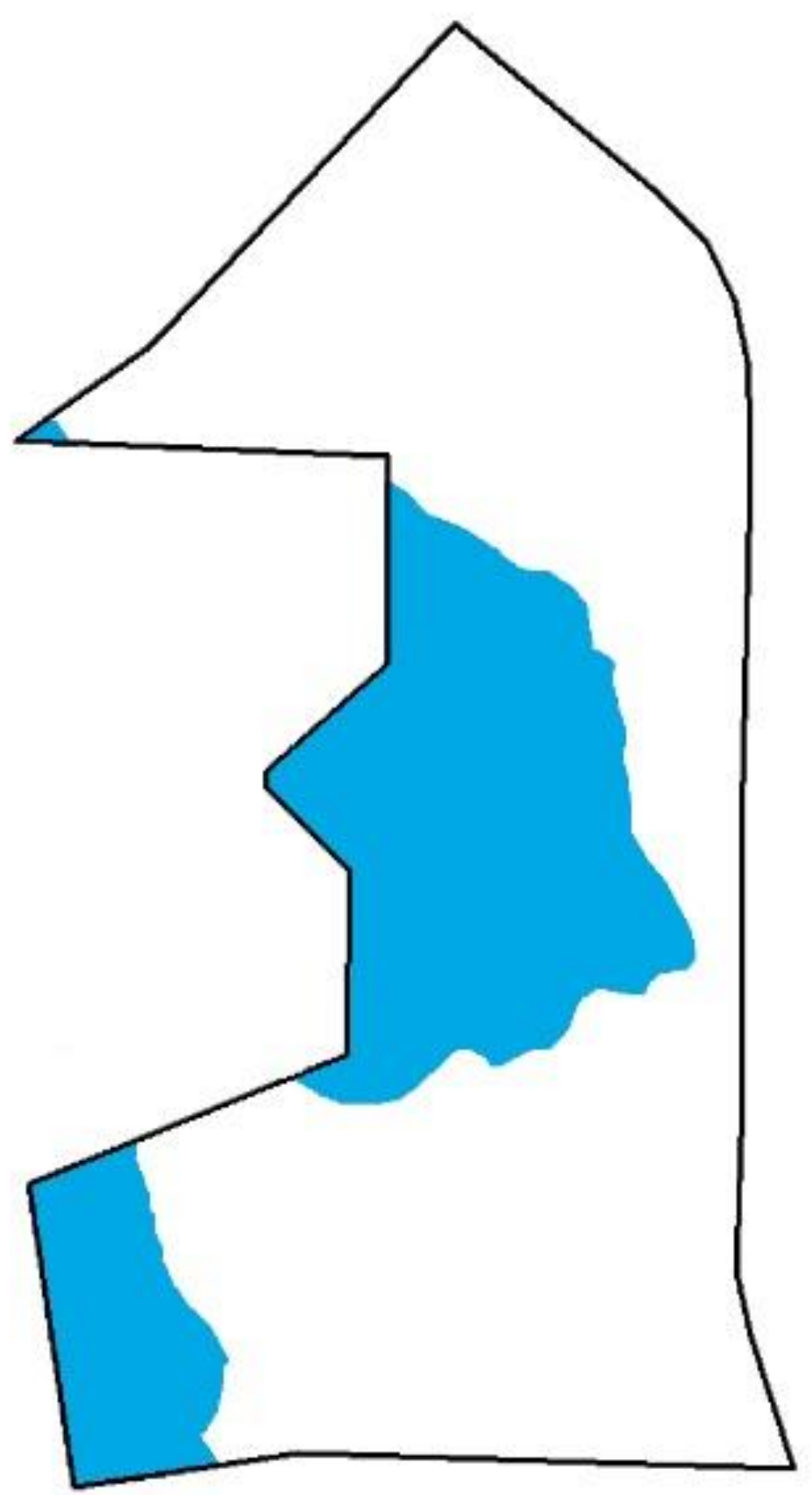




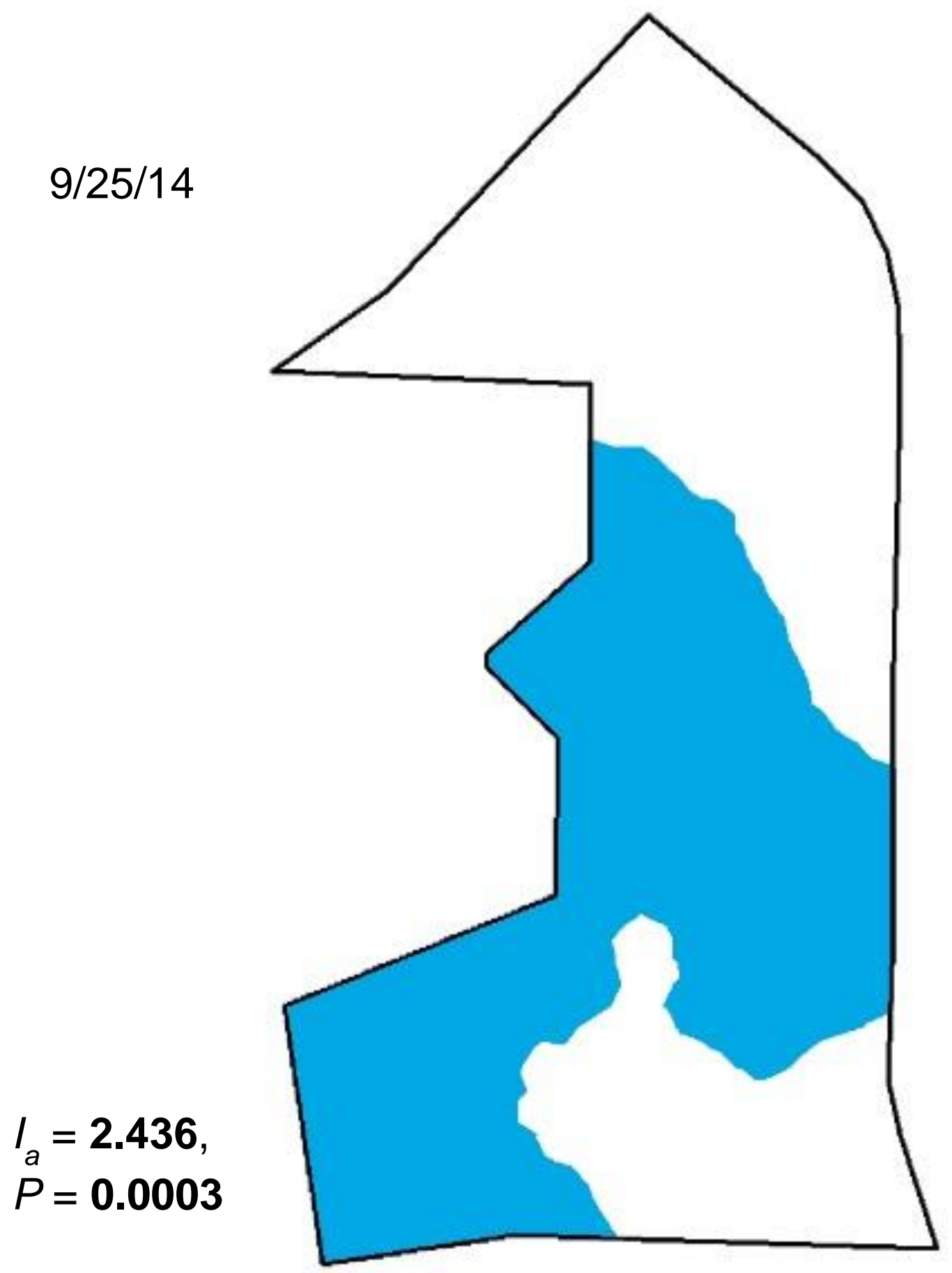




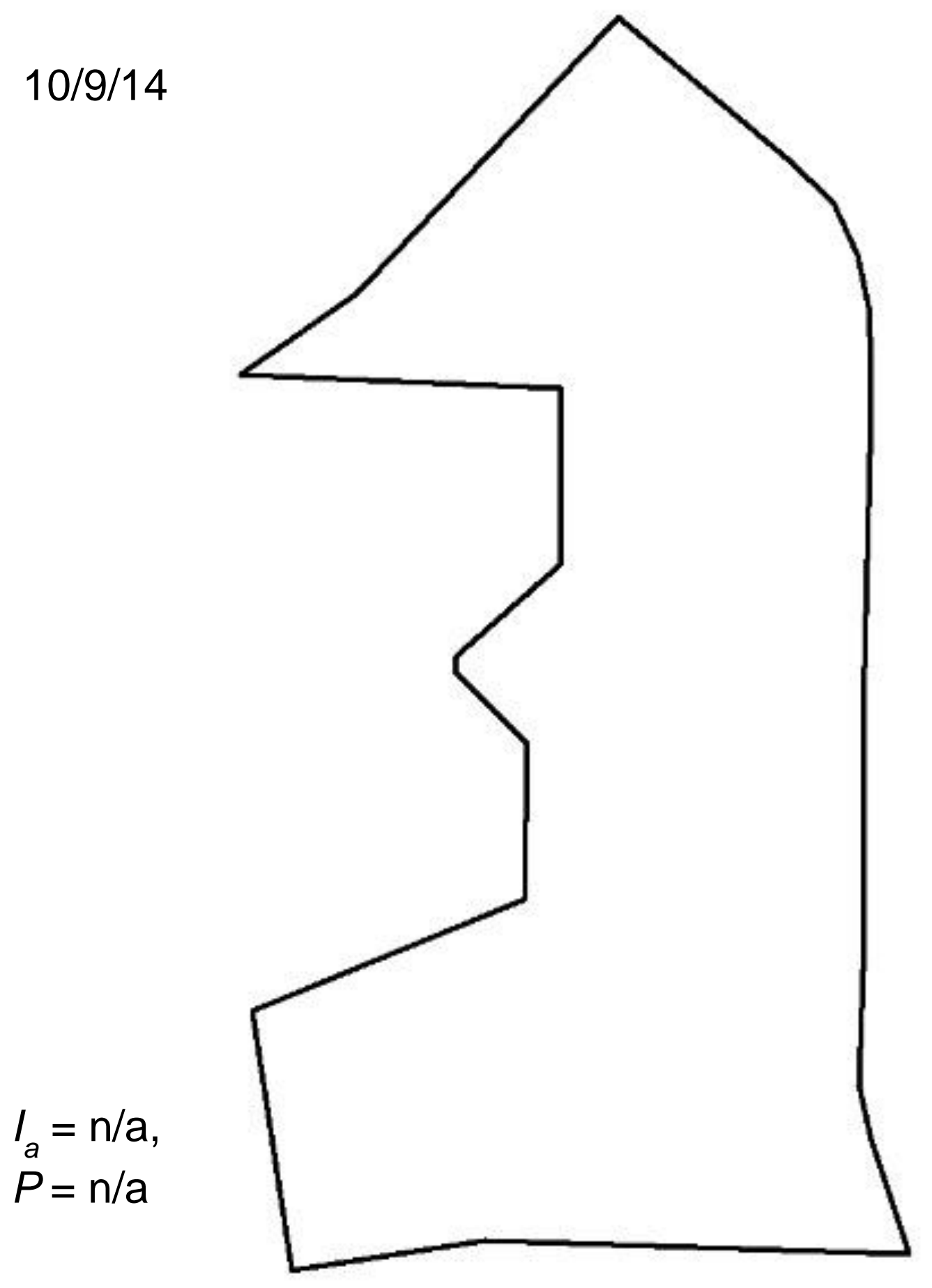

xix 


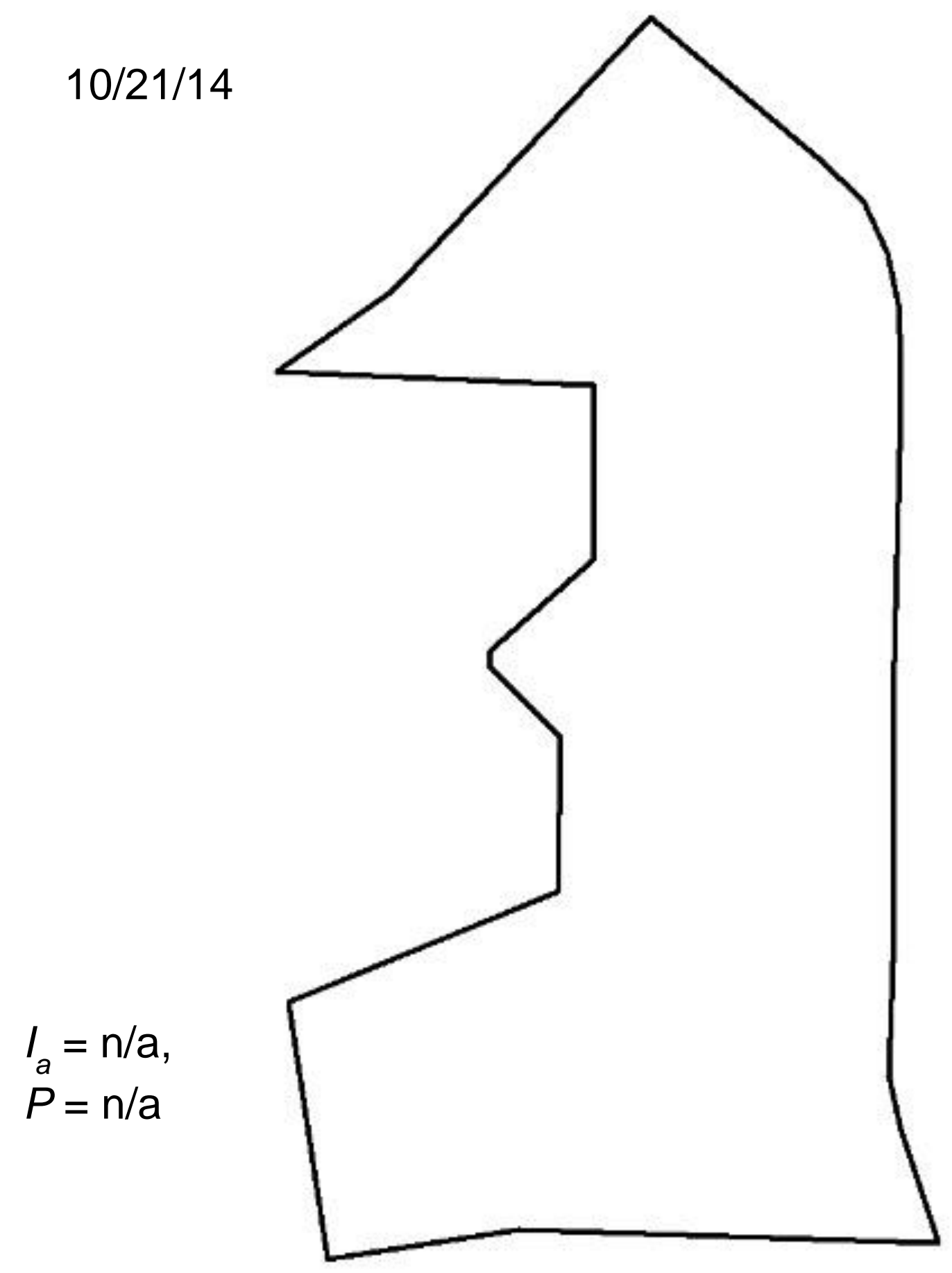

